\title{
KAIZEN - IMPLEMENTAÇÃO NA INDÚSTRIA DE AUTOPEÇAS: RESULTADOS NA REDUÇÃO DAS PERDAS NA ÁREA PRODUTIVA.
}

\author{
Dissertação apresentada à Escola \\ Politécnica da Universidade de São Paulo \\ para obtenção do Título de Mestre em \\ Engenharia.
}

SÃO PAULO 


\section{KAIZEN - IMPLEMENTAÇÃO NA INDÚSTRIA DE AUTOPEÇAS: RESULTADOS NA REDUÇÃO DAS PERDAS NA ÁREA PRODUTIVA.}

Dissertação apresentada à Escola

Politécnica da Universidade de São

Paulo para obtenção do Título de

Mestre em Engenharia.

Área de Concentração: Projeto de Fabricação

Orientador: Professor Doutor Gilberto

Francisco Martha de Souza

SÃO PAULO 
Este exemplar foi revisado e alterado em relação à versão original, sob responsabilidade única do autor e com a anuếncia de seu orientador.

São Paulo, de outubro de 2008.

Assinatura do autor

Assinatura do orientador

FICHA CATALOGRÁFICA

Paniago, Argélio Lima

Kaizen - Implementação na indústria de autopeças : resultados na reduçāo das perdas na área produtiva / A.L. Paniago. -ed.rev. -- Săo Paulo, 2008.

$132 \mathrm{p}$.

Dissertaçāo (Mestrado) - Escola Politécnica da Universidade de São Paulo. Departamento de Engenharia Mecânica.

1.Produtividade industrial 2.Amostragem 3.Administraçāo (qualidade) 4.Controle da qualidade I. Universidade de São Paulo. Escola Politécnica. Departamento de Engenharia Mecânica II. t. 


\section{DEDICATÓRIA}

Dedico este trabalho à minha esposa Sandra, sem ela eu não o teria realizado. 
"Faça o que for necessário, depois o possível, de repente você estará fazendo o impossível."

São Francisco de Assis 


\section{AGRADECIMENTOS}

Agradecimento especial aos participantes do levantamento amostral que deu subsídios à realização deste trabalho.

A todos que me apoiaram, opinaram e incentivaram, mas também aqueles que colocaram obstáculos, porque estes obstáculos fizeram com que fosse fortalecida a disposição de continuar em frente na execução e finalização do trabalho.

Ao meu Orientador Professor Gilberto, além de tudo, pelo incentivo e motivação. 


\section{RESUMO}

A metodologia KAIZEN é divulgada pelo mundo todo e no Brasil há muitas empresas fazendo uso dela para melhorarem seus resultados. Neste trabalho o histórico e conceitos do KAIZEN são apresentados e são as bases para o levantamento amostral realizado. Este tipo de pesquisa foi utilizado para, no ambiente da indústria de autopeças no Brasil que aplicam a metodologia KAIZEN, se conhecer como os fundamentos desta metodologia estão sendo utilizados, quais os reais resultados alcançados e quais ações são encontradas que, através do KAIZEN, encaminham a estes resultados. Foi desenvolvido um questionário como instrumento de pesquisa e este foi distribuído às empresas de interesse a este trabalho. Cada questão colocada tem seus resultados apresentados em forma de distribuição de respostas para cada opção e a discussão final utiliza estas distribuições de respostas para suas fundamentações e a conclusão do trabalho.

Palavras chave: Produtividade Industrial. Amostragem. Administração (Qualidade). Controle da Qualidade 


\section{ABSTRACT}

KAIZEN Methodology is known all over the world and in Brazil it has many companies making use of it to improve their results. In this work, the description and concepts of the KAIZEN are presented and are the bases for the survey done. This type of research was developed in the environment of the auto parts industry that applies KAIZEN methodology in Brazil to know how this methodology is being used, which the real results reached and which actions are found that, through the KAIZEN, direct to these results. A questionnaire was designed as research instrument and distributed to the companies of interest to this work. Each question has its results presented in form of distribution for each option and the final discussion uses these distributions as bases to the conclusions of the work.

Key words: Industrial Productivity. Survey. Quality Administration. Quality Control. 


\section{LISTA DE TABELAS}

Tabela 1 Hierarquia de envolvimento no KAIZEN (Imai, 1992) 24

$\begin{array}{lll}\text { Tabela } 2 & \text { Escala de credibilidade para amostras pequenas. }\end{array}$ Adaptado de Sudman (1993)

Tabela 3 Principais produtos das empresas respondentes. 


\section{LISTA DE FIGURAS}

$\begin{array}{lll}\text { Figura } 1 \text { Atividades KAIZEN (Brunet e New, 2003) } & 21\end{array}$

Figura 2 Hierarquia nas Indústrias de tecnologia 22

Figura 3 Hierarquia de participação na inovação e KAIZEN (Conceito 22 Oriental)

Figura 4 Hierarquia de participação na inovação (Conceito Ocidental) 23

Figura 5 Inovação Sozinha 26

Figura 6 Inovação mais KAIZEN 26

Figura 7 Interação entre os Ciclos PDCA e PaFVA com o KAIZEN e 27 Manutenção

Figura 8 Teste de Teoria no Processo de Pesquisa tipo levantamento 35 amostra I - Adaptado de Forza (2002)

Figura 9 Índice de retorno de respostas $\quad 47$

Figura 10 Distribuição dos respondentes do ramo de Autopeças por porte 50 da empresa conforme SEBRAE

Figura 11 Distribuição dos respondentes de ramos industriais diversos por 50 porte da empresa conforme SEBRAE

Figura 12 Distribuição dos respondentes do ramo de autopeças por número 51 de funcionários conforme Sindipeças

Figura 13 Distribuição dos respondentes do ramos industriais diversos por 51 número de funcionários conforme Sindipeças

Figura 14 Distribuição dos respondentes conforme origem do capital das 52 empresas.

Figura 15 Distribuição das respostas à questão 1 do Bloco B.

Figura 16 Distribuição das respostas à questão 2 do Bloco B. 63

Figura 17 Distribuição das respostas à questão 3 do Bloco B. 63

Figura 18 Distribuição das respostas à questão 4 do Bloco B. 64

Figura 19 Distribuição das respostas à questão 5 do Bloco B. 65

Figura 20 Distribuição das respostas à questão 6 do Bloco B. 66

Figura 21 Distribuição das respostas à questão 7 do Bloco B. 67

Figura 22 Distribuição das respostas à questão 8 do Bloco B 68 
Figura 23 Distribuição das respostas à questão 9 do Bloco B 69

Figura 24 Distribuição das respostas à questão 1 do Bloco C

Figura 25 Distribuição das respostas à questão 2 do Bloco $\mathrm{C}$

Figura 26 Distribuição das respostas à questão 3 do Bloco C 72

Figura 27 Distribuição das respostas à questão 4 do Bloco C 73

Figura 28 Distribuição das respostas à questão 5 do Bloco C

Figura 29 Distribuição das respostas à questão 6 do Bloco C 75

Figura 30 Distribuição das respostas à questão 7 do Bloco C 76

Figura 31 Distribuição das respostas à questão 8 do Bloco C

Figura 32 Distribuição das respostas à questão 9 do Bloco C 78

Figura 33 Distribuição das respostas à questão 1 do Bloco D 79

Figura 34 Distribuição das respostas à questão 2 do Bloco D 80

Figura 35 Distribuição das respostas à questão 3 do Bloco D

Figura 36 Distribuição das respostas à questão 4 do Bloco D 82

Figura 37 Distribuição das respostas à questão 5 do Bloco D 83

Figura 38 Distribuição das respostas à questão 6 do Bloco D 84

Figura 39 Distribuição das respostas à questão 7 do Bloco D 85

Figura 40 Distribuição das respostas à questão 8 do Bloco $D$

Figura 41 Distribuição das respostas à questão 9 do Bloco D 87

Figura 42 Distribuição das respostas à questão 1 do Bloco $\mathrm{E} \quad 88$

Figura 43 Distribuição das respostas à questão 2 do Bloco E 89

Figura 44 Distribuição das respostas à questão 3 do Bloco $\mathrm{E} \quad 90$

Figura 45 Distribuição das respostas à questão 4 do Bloco E 91

Figura 46 Distribuição das respostas à questão 5 do Bloco E 92

Figura 47 Distribuição das respostas à questão 6 do Bloco $\mathrm{E}$

Figura 48 Distribuição das respostas à questão 7 do Bloco E

Figura 49 Distribuição das respostas à questão 8 do Bloco E

Figura 50 Comparação de resultados relacionados à mudança cultural e 97 sentimentos de ameaça devido as atividades KAIZEN

$\begin{array}{lll}\text { Figura } 51 \text { Comparação de resultados relacionados à nível de barreiras e } & 98\end{array}$ abertura de ambiente às mudanças 
Figura 52 Comparação de resultados relacionados a condução de atividades de melhoria pela Liderança do chão de fábrica e respectiva participação dos operadores.

Figura 53 Comparação de resultados relacionados à participação do pessoal no programa de sugestões e participação dos operadores no programa KAIZEN

Figura 54 Comparação de resultados relacionados ao conhecimento de 102 eliminação de perdas por parte dos Operadores.

Figura 55 Comparação de resultados relacionados a participação da Área 103 de Recursos Humanos e fatores de sucesso das atividades do KAIZEN

Figura 56 Comparação entre respostas de empresas que obtiveram ganhos 104 entre $1 \%$ e $3 \%$ sobre seus faturamentos. 


\section{LISTA DE SIGLAS}

CCQ Círculos de Controle de Qualidade

$\mathrm{CQ} \quad$ Círculos de qualidade

JIT Just in Time ( No tempo exato)

PDCA Plan; Do; Check; Act (Planejar; Fazer; Verificar; Agir)

PaFVA Padronizar; Fazer; Verificar; Agir

SMED Single Minute Exchange Die (Troca de molde em um dígito de minuto)

Sindipeças Sindicato Nacional da Indústria de Componentes para Veículos Automotores

SEBRAE Serviço Brasileiro de Apoio às Micro e Pequenas Empresas

TPM Total Productive Maintenance (Manutenção Produtiva Total)

TQM Total Quality Management (Gerenciamento Total da Qualidade) 


\section{SUMÁRIO}

\section{RESUMO}

\section{ABSTRACT}

\section{LISTA DE TABELAS}

\section{LISTA DE FIGURAS}

\section{LISTA DE SIGLAS}

1 INTRODUÇÃO

1.1 Considerações iniciais 16

$\begin{array}{ll}1.2 \text { Objetivo } & 17\end{array}$

2 HISTÓRICO 18

3 REVISÃO BIBLIOGRÁFICA 20

3.1 Conceito do KAIZEN 20

3.2 KAIZEN como iniciativas fora do contexto do trabalho 21

3.3 KAIZEN e Inovação 22

3.4 KAIZEN com enfoque na qualidade 26

3.5 KAIZEN na administração e relações industriais 28

3.6 KAIZEN e suas ferramentas 30

3.7 Conceito do KAIZEN utilizado neste trabalho 31

4 METODOLOGIA 32

4.1 Porque foi escolhida esta metodologia 32

4.2 Estudos preliminares anteriores ao projeto da 33 pesquisa

4.3 Questão a ser respondida 34

5 PROJETO DO LEVANTAMENTO AMOSTRAL 36

5.1 Preparação do Projeto 36

5.2 Definição da amostragem 39

5.3 Desenvolvimento do Questionário 43

5.4 Encaminhamento junto às Empresas e 45

Respondentes

5.5 Teste Piloto 45

5.6 Análise da amostragem 46 
6 QUESTIONÁRIO COMENTADO 54

7 RESULTADOS 61

8 DISCUSSÃO 95

8.1 Resultados das empresas que utilizam a metodologia 95 KAIZEN

8.2 Condições para obtenção dos resultados positivos 96

8.3 Situação da utilização e entendimento da 105 metodologia KAIZEN nas empresas

9 CONCLUSÃO 109

REFERÊNCIAS 


\section{INTRODUÇÃO}

\subsection{Considerações iniciais}

Nos trabalhos dentro da manufatura, existe, entre as dificuldades normais das tarefas, uma necessidade de questionar as formas de solucionar os problemas que aparecem, de direcionar a busca às melhores práticas e de verificar se acontecem estas práticas, uma vez padronizadas corretamente.

É verificado que as atividades acontecem de forma, muitas vezes, desordenada. Para entender o que realmente acontece, basta se colocar na posição de observação participante e perceber a necessidade de metodologias ou ferramentas para direcionar mais eficazmente os resultados.

Através de leitura de textos sobre sistemas de gestão de produção e de informações sobre a experiência de trabalhos com grande influência dos sistemas implementados pelas "Matrizes" de empresas multinacionais, surge o contato com a palavra KAIZEN. A princípio, nada mais que uma palavra japonesa que significa melhoria contínua. Mais tarde se percebe que este significado é muito mais amplo e que a força do KAIZEN não está na tradução pura e simples da palavra e sim algo maior, com um poder transformador imenso. Claro que esta percepção não acontece com estudos e longas leituras, pois está na prática, no exercício. Algo que demora na maturação, pelo menos é o que mostra a experiência.

Há cada vez mais o interesse pelo tema, na intenção de se utilizar mais esta maneira de fazer as coisas acontecer dentro da manufatura. Afortunadamente, existem os contatos com profissionais que conhecem muito o tema e que mostram a quantidade de oportunidades que há no meio fabril, de reduzir perdas, aumentar a eficiência, enfim, melhorar o resultado das empresas, empregando um elenco de ferramentas cuja maior estratégia seria a do trabalho em equipe.

Certa vez, o consultor Washington Tana, especialista em KAIZEN, fez o comentário no qual afirma que se pudesse iria até seu antigo empregador e pediria desculpas por ter trabalhado de forma errada por tanto tempo (Informação verbal) ${ }^{1}$.

\footnotetext{
${ }^{1}$ Apresentação de uma Consultoria. Guarulhos, SP. Março 2005. Palestra proferida na ocasião do início dos trabalhos da Consultoria na Empresa Metalúrgica de Autopeças.
} 
O que ele quis dizer, após ter trabalhado por muitos anos em uma grande indústria multinacional, era que o "jeito" que trabalhara até conhecer o KAIZEN era obsoleto e com resultados pífios.

A vivência do autor em muitas transformações positivas, além das informações de outras tantas em trabalhos relacionados a metodologia KAIZEN, fez com se despertasse o interesse no tema e, assim, o desenvolvimento deste trabalho.

As questões levantadas e discutidas dentro do contexto brasileiro seria uma forma de contribuição aos iniciantes e veteranos nos processos ligados ao KAIZEN. Estes profissionais poderiam se situar dentro do universo dos sistemas de gestão, notadamente aqueles cuja aplicação do KAIZEN está em curso.

\subsection{Objetivo}

O objetivo deste trabalho é o de responder, dentro do ambiente do setor de manufatura de autopeças no Brasil que utiliza a metodologia KAIZEN, às seguintes questões:

- Como está a utilização da metodologia KAIZEN nestas empresas?

- Qual é o entendimento que se tem do tema?

- Quais são os resultados efetivos?

Primeiramente é apresentado um breve panorama histórico da evolução da metodologia KAIZEN, em qual contexto houve seu aparecimento e como ela se transformou no tempo, para se tornar naquilo que se utiliza atualmente. A seguir é apresentado o método de levantamento amostral, chamado na língua inglesa por Survey, o método de validação do estudo e embasamento teórico.

Apresenta-se como foi feito o planejamento da pesquisa. Na seqüência, o levantamento amostral é detalhado, analisado e seus resultados tabulados a fim de serem discutidos.

Finalmente encerra-se o trabalho ressaltando os principais itens concluídos e apresentando oportunidades para continuidade em futuras pesquisas. 


\section{HISTÓRICO}

Para traçar um histórico da evolução do KAIZEN, considera-se o histórico do KAIZEN e do Sistema de Produção Toyota (Manufatura Enxuta) como uma evolução em que um sempre esteve atrelado ao outro. Brunet e New (2003) mencionam os textos de Elgar e Smith (1994), Senge (1990) e Utterback (1995) para afirmar que o KAIZEN é considerado o elemento chave no sistema de gestão japonês e o conceito é apresentado como o princípio escondido da chamada "Manufatura Enxuta".

A origem do, assim chamado, pensamento enxuto ocorreu no chão de fábrica das empresas japonesas em particular nas inovações na Toyota Motor Corporation (Moden, 1983; Ohno, 1988, Shingo, 1996), estas inovações surgiram do resultado de escassez de recursos e de um mercado competitivo no ambiente doméstico da época no Japão.

Com a liderança de Taiichi Ohno, nos anos 1950, na fábrica de motores da Toyota, foram realizados trabalhos para eliminar os desperdícios na manufatura, ferramentas de melhoria foram desenvolvidas, tais como entrega no tempo exato (just in time), sistema de manufatura puxada com a utilização de cartões (Kanbans), respeito aos funcionários, alto nível de análise e solução de problemas por todo o pessoal da Produção e sistemas a prova de erros (Pokayokes).

O objetivo era tornar o sistema produtivo "enxuto", eliminando os desperdícios ou perdas do fluxo de produção (7 fontes de desperdícios Toyota) representando uma alternativa ao sistema de produção em massa (grandes lotes que ocultam os desperdícios ou perdas). Na década de 1960 este trabalho foi estendido às fábricas de montagem de veículos.

Nos anos 1970, houve o envolvimento de toda cadeia de fornecimento da Toyota, com a mesma finalidade, eliminação dos desperdícios. Neste estágio os "segredos" do Sistema Toyota de Produção foram revelados ao mundo através dos manuais dos fornecedores. Mais de uma década se passou para que estes manuais fossem traduzidos para o inglês ( Schonberger, 1982; Hall, 1983; Monden, 1983; Sandras, 1989 e Shingo, 1996).

$O$ interesse era ainda pequeno até que as diferenças entre a Toyota e os outros fabricantes de veículos fossem ressaltadas no livro A Máquina que mudou o mundo (The Machine that Changed the World) (Womack et al., 1992), quando foi 
apresentado o conceito de produção enxuta (manufatura enxuta) e que os problemas de manufatura e tecnologia são problemas universais frente à gestão de negócios em geral (Womack et al., 1992).

Com a superioridade da manufatura enxuta em relação à produção em massa, empresas ocidentais imitaram as técnicas de chão de fábrica e as partes estruturais da manufatura enxuta, mas com dificuldades de introduzir a cultura organizacional necessária para a correta aplicação do dito "pensamento enxuto".

As primeiras tentativas tiveram apenas impacto localizado (Holweg e Pil, 2001) e a fraqueza da manufatura enxuta, nesta época (1990) foi ser baseada somente nos conceitos da indústria automotiva, a dificuldade de lidar com a variação da demanda e a negligência ao fator humano.

Houve, depois de 1990, uma migração de trabalhos para fora do chão de fábrica. Esta extensão foi acelerada pela promoção de casos de sucesso em empresas ocidentais de diversos setores e negócios, que reproduziam o uso dos princípios do pensamento enxuto: identificação do valor do cliente; gestão da corrente do valor; desenvolvimento da capacidade do fluxo de produção; uso do mecanismo de "puxar" para suportar o fluxo nas operações "gargalo" e perseguição à perfeição através da redução a zero de todas as formas de desperdícios no sistema de produção (Womack e Jones, 1996). Houve uma alteração de focos nos trabalhos de redução das perdas conforme a época: Qualidade - início dos anos 90; Qualidade, Custo e Entregas no final dos anos 90; Valor do cliente de 2000 em diante.

Em meados dos anos 1990, o conceito de fluxo de valor foi estendido às necessidades dos clientes até as fontes de matéria-prima (Hines e Rich, 1997; Rother e Shock, 1996), isto fez a ligação entre a manufatura enxuta e a cadeia dos fornecedores. O conceito de produção puxada estendido para além dos limites de uma única fábrica para incluir as posições anteriores e posteriores na cadeia produtiva. 


\section{REVISÃO BIBLIOGRÁFICA}

\subsection{Conceitos do KAIZEN}

Sempre existiu uma ambigüidade e inconsistência sobre o tema, pois muitas vezes ele é colocado como uma espécie de "almoço grátis" de onde magicamente aparecem as soluções para os problemas (Brunet e New,2003).

KAIZEN, palavra japonesa para melhoria, envolve um conjunto de atividades no chão de fábrica ou outros locais de trabalho para melhorar as operações e ambiente (Brunet; New.,2003). Há uma aproximação entre os conceitos do KAIZEN e estudos passados nas relações industriais, desde Elton Mayo (1959) na Teoria das Relações Humanas e Maslow (1970).

Há o consenso entre os escritores em três pontos sobre o KAIZEN:

- KAIZEN é contínuo - Jornada sem fim em busca da qualidade e eficiência

- Natureza incremental.

- Ele é participativo - Ações interativas de inteligência e trabalho do pessoal, gerando benefícios intrínsecos da vida no trabalho dos empregados.

Lillrank e Kano(1989) observam que as idéias de Círculos de Qualidade(CQ) e Gerenciamento Total da Qualidade (TQM) estão fortemente associadas mas não são idênticas às do KAIZEN, o qual está ligado com os recentes conhecimentos na área de gestão divulgados por Nonaka e Takeuchi(1997, o desenvolvimento e comunicação do conhecimento), Balanced Scorecards de Kaplan e Norton(1996, o monitoramento contínuo da variação do processo). De Haan et al.(2001) observam a importância do KAIZEN para os mecanismos de controle de produção japonesa.

A generalidade e simplicidade do KAIZEN são ao mesmo tempo suas fraquezas e suas forças. Imai(1992) chama a atenção para o fato de que o conceito está tão aprofundado dentro dos gerentes e trabalhadores que muitas vezes agem sem perceberem que estão seguindo a filosofia KAIZEN. Para outros é uma ferramenta ou uma prática estritamente definida e muitos textos importantes e autoridades nem mesmo usam a palavra quando mencionam atividades de melhoria 
contínua, apesar de sua relevância. A palavra não aparece no texto Ideologia da Manufatura de Tsutsui(1988), no seu importante trabalho sobre como o Taylorismo se desenvolveu na manufatura moderna japonesa, também não aparece distintivamente nos trabalhos de Deming ou Feigenbaum. Esta onipresença combinada com sua invisibilidade faz com que a pesquisa empírica sobre o tema seja algo extremamente desafiante. A notável conseqüência de uma grande variedade de interpretações do KAIZEN é que ele permanece livre de qualquer controle ou influência e seus proponentes podem colher os melhores elementos de outros sistemas e metodologias.

\subsection{KAIZEN como iniciativas fora do contexto do trabalho}

Em sua pesquisa Brunet e New (2003) utilizam a definição que considera o KAIZEN uma atividade contínua e gradual, fora do contrato explícito do participante, para identificar e conquistar resultados que o empregado acredita que contribui para os objetivos da organização, excluindo a formulação da estratégia e o projeto dos sistemas de produção. Para o melhor entendimento de seus conceitos a respeito da organização do KAIZEN, fizeram uma representação gráfica em dois eixos, na qual o eixo vertical seria o grau em que o KAIZEN está sistematizado e organizado e o eixo horizontal o grau no qual a gerência especifica ou influencia as atividades KAIZEN (Figura 1).

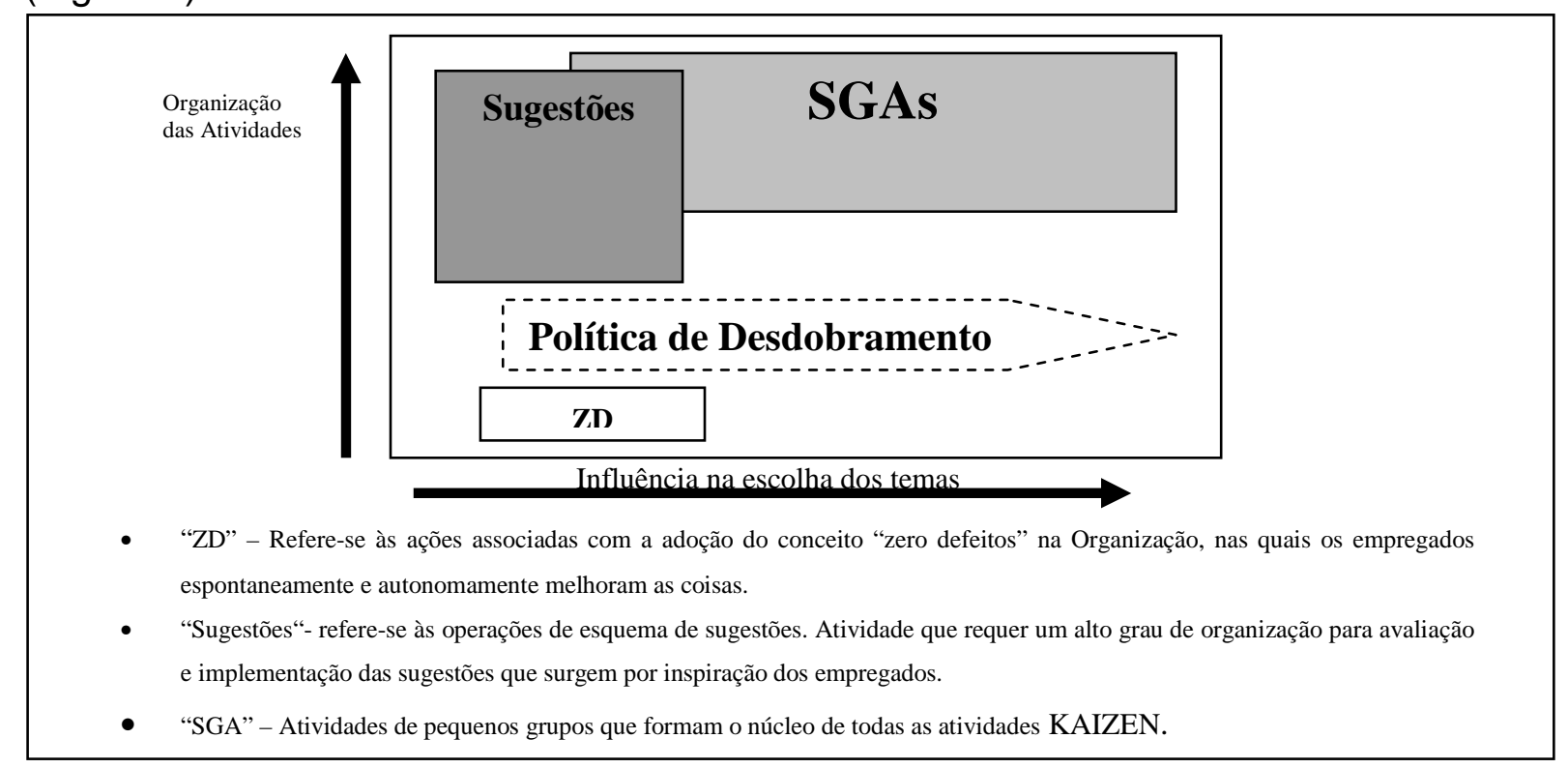

Figura 1 - Atividades KAIZEN (Brunet e New, 2003) 


\subsection{KAIZEN e Inovação}

A Metodologia KAIZEN pode ser considerada um contraponto à estratégia da inovação. A estratégia da inovação é apropriada para mercados em expansão, grandes quantidades, recursos abundantes, baixo custo, preocupação com aumento das vendas maior que a de se reduzir os custos. A metodologia KAIZEN é apropriada para uma situação com excesso de capacidade, muita concorrência, consumidores com mudança de valores e necessidade de lançamento de produtos novos mais rapidamente. Como o ambiente atual está cada vez mais competitivo fica mais apropriado para a aplicação da Metodologia KAIZEN (Imai, 1992)..

O começo de um trabalho voltado para o KAIZEN seria o do reconhecimento, por parte da Organização, de que a operação tem problemas e estes problemas são multifuncionais. No Ocidente esta situação é tratada com a resolução de conflitos, enquanto que na visão oriental o enfoque é sistêmico e no processo (Imai, 1992). Não necessitando de técnicas sofisticadas, não há porque não se fazer nada, mas exige esforço e cooperação de todos.

Imai(1992) mostra a diferença entre o ocidente e oriente em relação à distribuição de atividades de manutenção, melhorias e inovação(Figuras 2, 3 e 4).

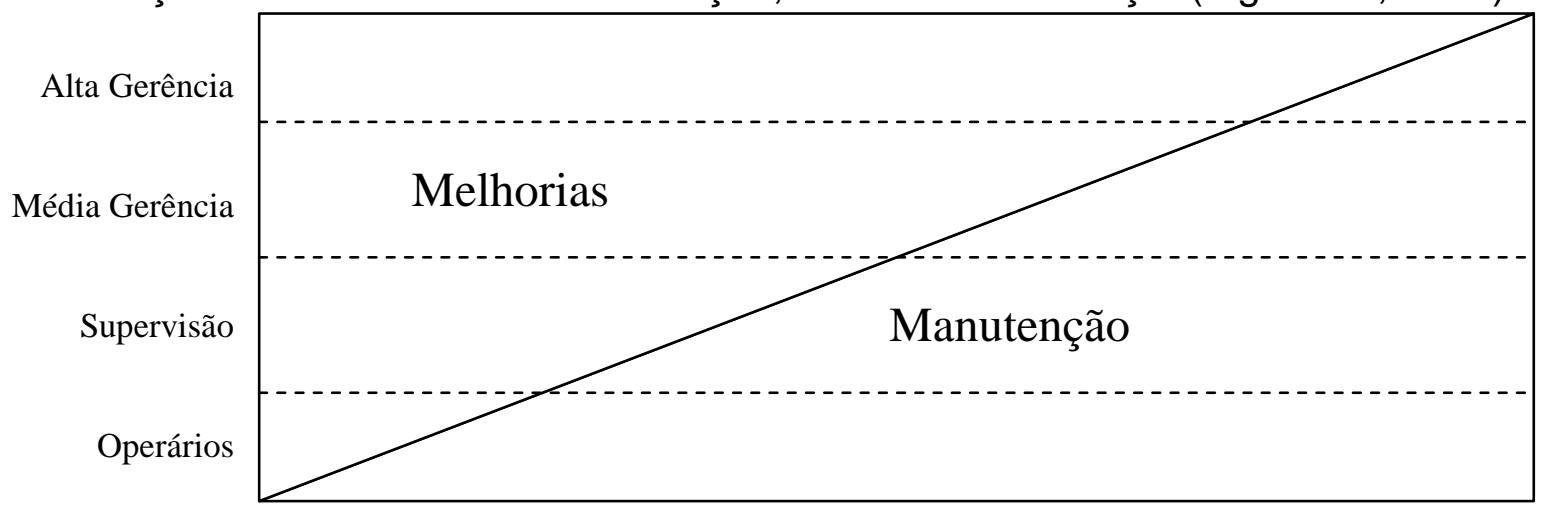

Figura 2 - Hierarquia nas Indústrias de tecnologia

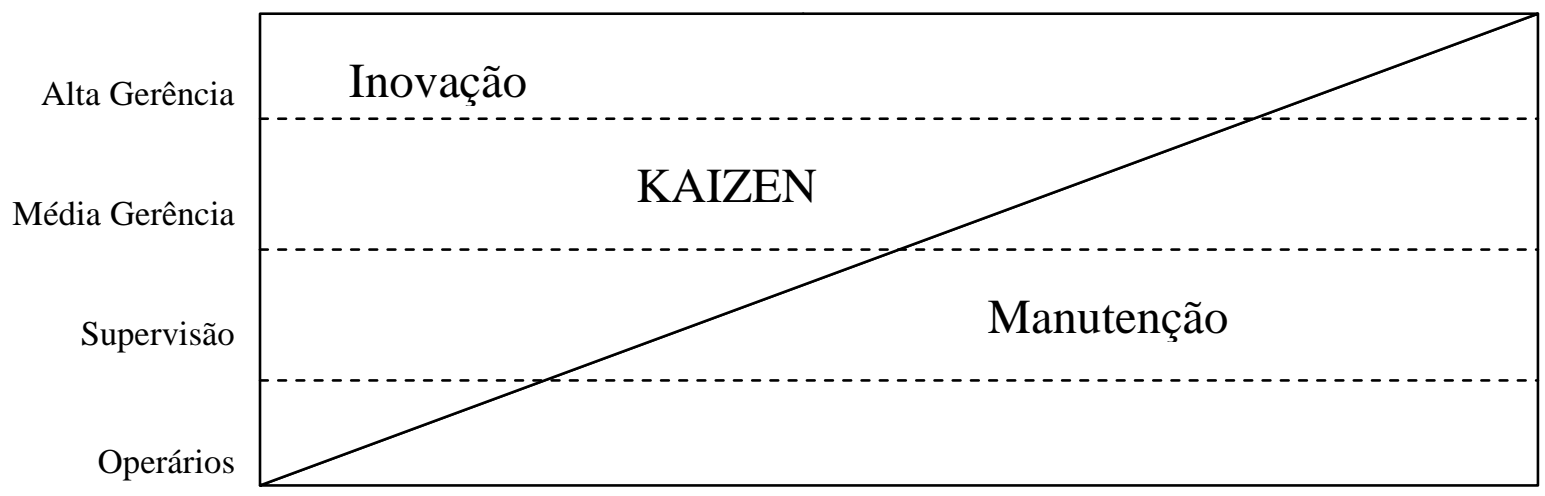

Figura 3 - Hierarquia de participação na inovação e KAIZEN (Conceito Oriental) 


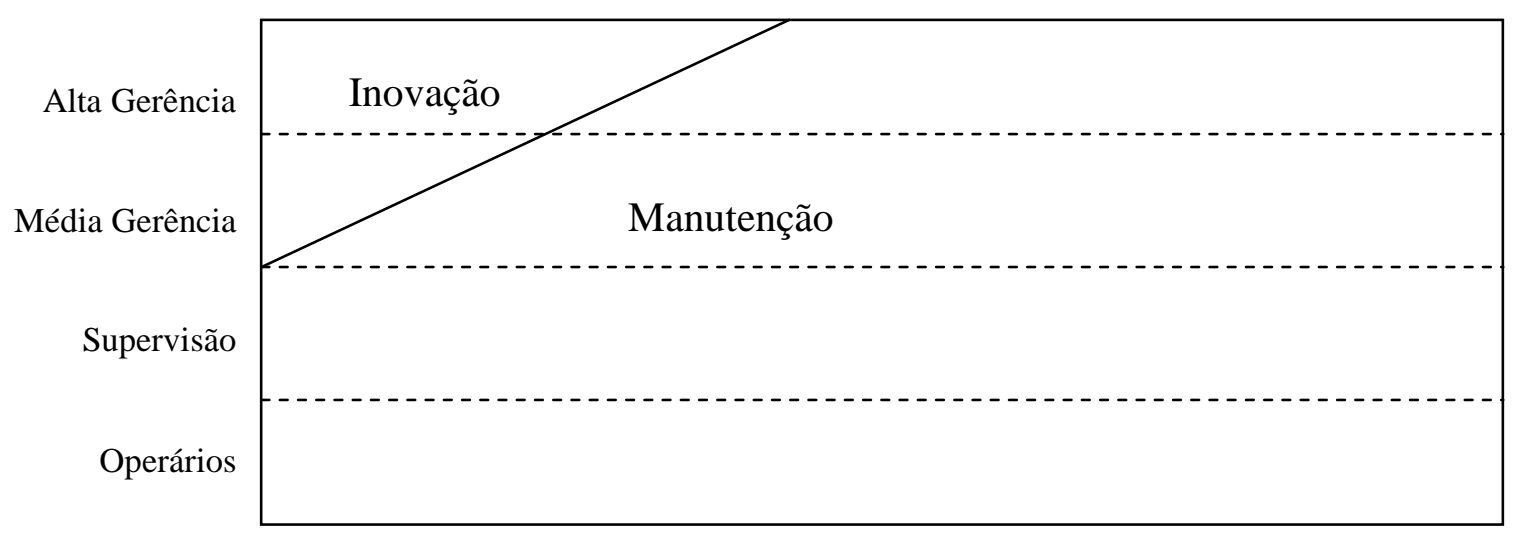

Figura 4 - Hierarquia de participação na inovação (Conceito Ocidental)

Segundo Irriai (1992), pode-se fazer algumas observações sobre a atitude e posicionarnento necessário em relação ao KAIZEN:

- As piores empresas são aquelas que não fazem nada a não ser manutenção do que já existe.

- KAIZEN não necessita de técnicas especializadas

- KAIZEN exige esforço de todos

- KAIZEN se adapta melhor às economias de crescimento lento

- Necessita de um sistema interno para recompensar os esforços de melhoramento e avaliação para resultados.

- No ocidente os engenheiros se orgulham do exercício teórico enquanto que no KAIZEN este posicionamento não é valorizado.

Imai (1992) apresenta o KAIZEN como um programa global no qual estão incluídas outras "ferramentas" como a Manutenção Produtiva Total (TPM), a Qualidade Total(TQM) e JIT (Just-in-Time). Assim, ele desenvolve o tema fazendo considerações nas quais o KAIZEN e a cultura organizacional apropriada não existem individualmente. KAIZEN exige um modo diferente de avaliação, pode ser orientado para a administração, ser direcionado para grupos ou pessoas, assumir forma multifuncional(Tabela 1). 
Tabela 1 - Hierarquia de envolvimento no KAIZEN (Imai, 1992)

\begin{tabular}{|c|c|c|c|}
\hline Alta Gerência & Média Gerência & Supervisores & Operários \\
\hline $\begin{array}{l}\text { Estar } \\
\text { determinada a } \\
\text { introduzir o } \\
\text { KAIZEN como } \\
\text { estratégia da } \\
\text { Corporação }\end{array}$ & $\begin{array}{l}\text { Distribuir e implantar } \\
\text { as metas do KAIZEN } \\
\text { orientadas pela Alta } \\
\text { Gerência. Através de } \\
\text { desdobramento do } \\
\text { plano de ação e de } \\
\text { administração multi- } \\
\text { funcional }\end{array}$ & $\begin{array}{l}\text { Usar o KAIZEN nas } \\
\text { tarefas funcionais }\end{array}$ & $\begin{array}{l}\text { Participar do KAIZEN } \\
\text { através do sistema de } \\
\text { sugestões e das } \\
\text { atividades em } \\
\text { pequenos grupos }\end{array}$ \\
\hline $\begin{array}{l}\text { Oferecer apoio e } \\
\text { direção para o } \\
\text { KAIZEN pela } \\
\text { distribuição de } \\
\text { recursos }\end{array}$ & $\begin{array}{l}\text { Usar o KAIZEN nas } \\
\text { capabilidades } \\
\text { funcionais }\end{array}$ & $\begin{array}{l}\text { Formular planos } \\
\text { para o KAIZEN e } \\
\text { oferecer orientação } \\
\text { aos Operários }\end{array}$ & $\begin{array}{l}\text { Praticar a disciplina } \\
\text { na área de trabalho }\end{array}$ \\
\hline $\begin{array}{l}\text { Estabelecer o } \\
\text { plano de ação } \\
\text { KAIZEN e as } \\
\text { metas multi- } \\
\text { funcionais }\end{array}$ & $\begin{array}{l}\text { Estabelecer, manter e } \\
\text { melhorar os padrões }\end{array}$ & $\begin{array}{l}\text { Melhorar a } \\
\text { comunicação com } \\
\text { os Operários e } \\
\text { manter o moral } \\
\text { elevado }\end{array}$ & $\begin{array}{l}\text { Envolver-se no } \\
\text { contínuo } \\
\text { desenvolvimento } \\
\text { próprio para tornar-se } \\
\text { melhor solucionador } \\
\text { de problemas }\end{array}$ \\
\hline $\begin{array}{l}\text { Realizar as } \\
\text { metas do } \\
\text { KAIZEN através } \\
\text { de } \\
\text { desdobramento } \\
\text { do plano de } \\
\text { ação e } \\
\text { verificações }\end{array}$ & $\begin{array}{l}\text { Conscientizar os } \\
\text { empregados sobre o } \\
\text { KAIZEN através de } \\
\text { programas intensivos } \\
\text { de treinamento }\end{array}$ & $\begin{array}{l}\text { Apoiar as } \\
\text { atividades em } \\
\text { pequenos grupos e } \\
\text { sistemas de } \\
\text { sugestões } \\
\text { individuais }\end{array}$ & $\begin{array}{l}\text { Ressaltar a habilidade } \\
\text { e a experiência no } \\
\text { desempenho do } \\
\text { serviço, aprendendo } \\
\text { várias funções }\end{array}$ \\
\hline $\begin{array}{l}\text { Criar sistemas, } \\
\text { procedimentos e } \\
\text { estruturas úteis } \\
\text { para o KAIZEN }\end{array}$ & $\begin{array}{l}\text { Ajudar os empregados } \\
\text { a desenvolverem } \\
\text { habilidades e } \\
\text { ferramentas para a } \\
\text { solução de problemas }\end{array}$ & $\begin{array}{l}\text { Introduzir a } \\
\text { disciplina na área } \\
\text { de trabalho } \\
\text { Oferecer sugestões } \\
\text { de KAIZEN }\end{array}$ & \\
\hline
\end{tabular}


Imai (1992) ressalta algumas das diferenças entre a avaliação, uma observação distanciada, e a realidade, pontos importantes para o KAIZEN, pois este exige uma participação direta nos assuntos:

- A avaliação da qualidade $\neq$ realidade da qualidade $\rightarrow$ Não se observando esta diferença não se pensa em melhorar os processos.

- A avaliação da produtividade $\neq$ realidade da produtividade

- Palavras chave do KAIZEN, esforço e melhoria.

- No ocidente ${ }^{2}$ apenas se olha para os resultados, sendo que no oriente se olha para os processos, são eles que, uma vez fortalecidos, produzirão os resultados.

- No KAIZEN deve-se acreditar que vai se ter retorno com o tempo.

- Como na Lei de Parkinson (Parkinson, 1955), sempre que uma inovação é realizada, ela deve ser acompanhada por uma série de esforços de KAIZEN para mantê-la e melhorá-la.

Abordando o KAIZEN no enfoque da qualidade através do TQM (Total Quality Management - Gerenciamento Total da Qualidade) temos que existem três bases para se obter esta Qualidade Total: hardware; software e o fator humano (Imai, 1992). Em primeiro plano o fator humano, através do treinamento. Desta forma podemos dizer que o fator referente às pessoas tem importância significativa no tema. KAIZEN, ele produz mudanças pequenas e contínuas enquanto que a inovação surge em grandes movimentos de tempos em tempos. A estratégia da inovação deve ocasionar o progresso em uma progressão do tipo "escada", mas geralmente não o faz (figura 5), se não houver a estratégia do KAIZEN para acompanhá-la (figura 6) a inovação estará sujeita a deterioração constante. Na realidade, não pode haver algo como uma constante estática, todos os sistemas estão destinados a se deteriorarem uma vez que tenham sido formados.

\footnotetext{
${ }^{2}$ Esta afirmação citada por Imai(1992) pode já ter atualmente, em muitas empresas do ocidente, um direcionamento como aquele seguido pelas empresas no oriente.
} 


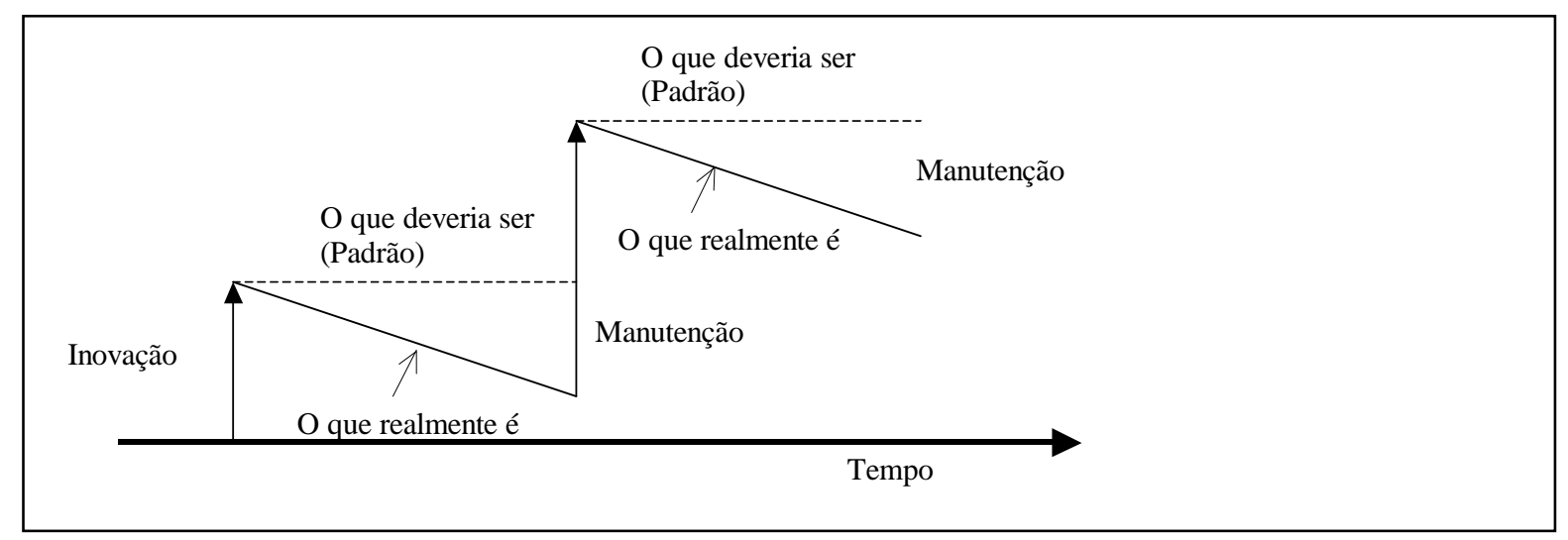

Figura 5 - Inovação Sozinha

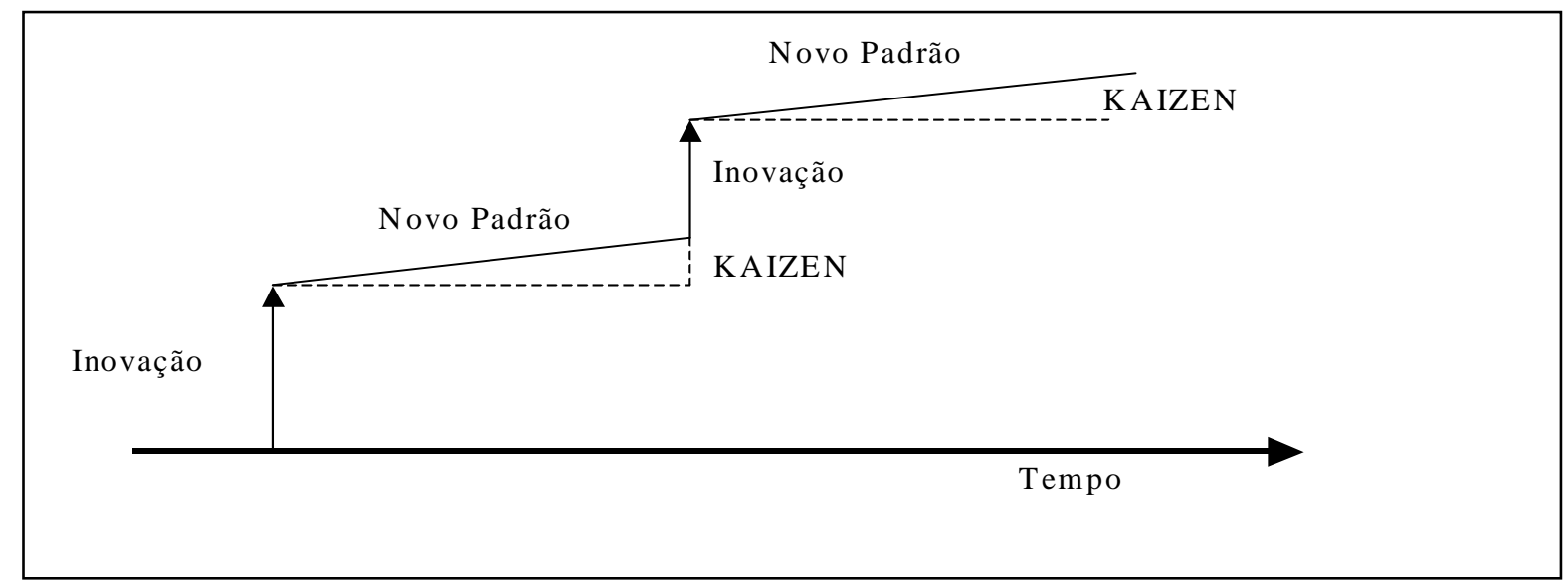

Figura 6 - Inovação mais KAIZEN

\subsection{KAIZEN com enfoque na qualidade}

O ciclo PDCA(Plan; Do; Check; Act)(Deming, 1986), é uma ferramenta essencial para a realização das melhorias e a garantia de que os benefícios delas continuem. Mesmo antes que o ciclo PDCA seja empregado é essencial que os padrões atuais sejam estabilizados. Neste plano, Check(Verificar) significa ver se o que foi planejado resultou na melhoria desejada e Act(Agir) significa evitar a repetição do erro e institucionalizar a melhoria como a nova prática a ser melhorada.

Este processo de estabilização é freqüentemente chamado de PaFVA(Padronizar; Fazer; Verificar; Agir)(Figura 7). Só quando o ciclo PaFVA está 
em atividade é que podemos passar para a melhoria dos padrões atuais através do PDCA. Qualquer processo de trabalho possui desvios no início e são necessários esforços para estabilizá-lo, isto é feito com o PaFVA (Imai, 1992).

Não pode haver melhoria onde não existem padrões, o ponto inicial da melhoria é saber-se onde está. Da mesma forma, deve haver um padrão preciso de medição para os gestores, antes de esforços em TQM e KAIZEN, pois os padrões existem para ser melhorados. Não é possível nem necessário padronizar todas as operações, no entanto os elementos cruciais devem ser mensurados e padronizados.

Imai (1992) considera ainda no enfoque do TQM como ferramenta dentro do âmbito do KAIZEN os Círculos de Qualidade (CCQ). Atividades essencialmente em grupo, para melhorias e resolução de problemas, estas atividades teriam as seguintes fases de trabalho:

- Escolha de um tema Jishu-kanri

- Entender a situação

- Determinar objetivo

- Fatores e medidas

- Resultados

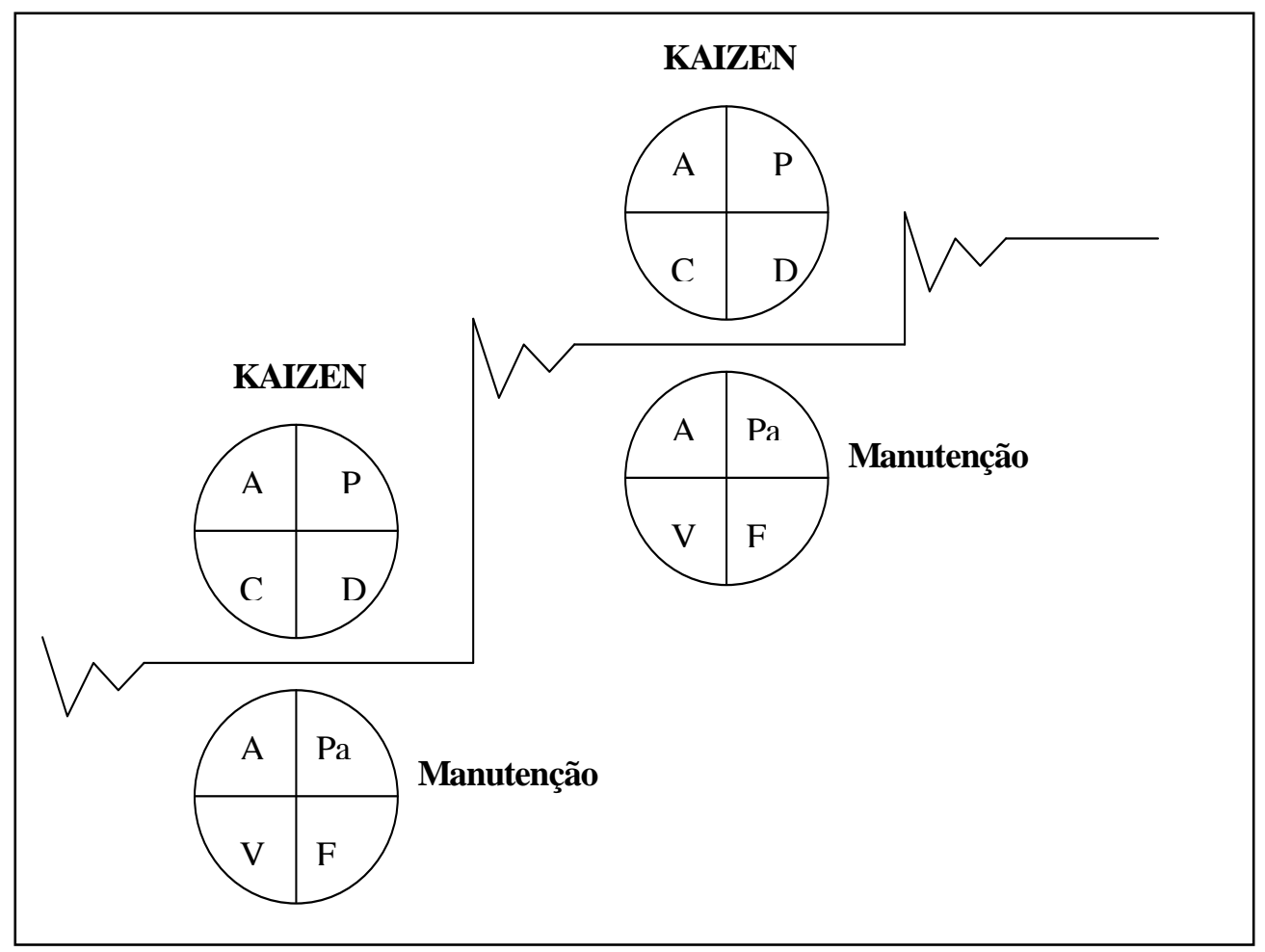

Figura 7 - Interação entre os Ciclos PDCA e PaFVA com o KAIZEN e Manutenção 
Uma vez alcançados os resultados das atividades do CCQ, há necessidade de se padronizar os resultados com a finalidade de se obter a:

- Autorização e responsabilidades individuais

- Transmissão de experiência individual à geração seguinte

- Transmissão de experiência e know-how à organização

- Acúmulo de experiência (Lições aprendidas)

- Distribuição de Know-how.

- Disciplina

\subsection{KAIZEN na administração e relações industriais}

O KAIZEN também pode ser orientado à administração, neste caso teria o enfoque sistêmico para identificar as perdas, aplicação do just-in-time, etc.

Através do KAIZEN orientado a grupos, numa área de trabalho, temos as atividades:

- Exercício da administração voluntária ou auto-gestão.

- Treinamento - com foco principal na resolução de problemas

- Envolvimento - Trabalho de conscientização orientada aos operários.

- Papel da gerência - orientação e apoio aos grupos.

- Atividades em pequenos grupos com trabalhos em temas diferenciados

- Esforço para a qualidade

Um dos enfoques do KAIZEN seria o da melhoria das Relações industriais:

- Confrontação x Cooperação - melhoria nas relações com resultados obtidos através da cooperação.

- Organização formal x informal - informalidade das atividades dos grupos de trabalho criando as melhorias e redução de perdas e desperdícios.

- Objetivo e trabalho para realização, fortalecimento da sensação de trabalho em grupo.

- Membros compartilham e coordenam suas funções

- Melhor comunicação entre os funcionários e departamentos. 
- Moral elevado do pessoal

- Operador com mais habilidades

- Grupo sustenta a si

- Relação de mão de obra e administração são melhoradas

Além do direcionamento geral aos grupos, também há KAIZEN orientado às pessoas, conscientizando-as, comprometendo-as aos objetivos de, pessoalmente:

- Melhorar no próprio trabalho

- Economia de energia, materiais e outros recursos

- Melhorar ambiente de trabalho

- Melhorar máquinas e processos, dispositivos e ferramentas

- Melhorar o trabalho em escritórios

- Melhorar a qualidade do produto

- Melhorar relação com o consumidor

Dentro da administração multifuncional orientada pelas atividades do KAIZEN, temos o exemplo de aplicação na Toyota, onde as etapas de desenvolvimento de produtos são conduzidas por este tipo de gestão, atuando como os papéis tradicionais dos departamentos em cada fase deste desenvolvimento (Moden, 1983):
a) Planejamento do produto
b) Projeto de produto
c) Preparação da produção
d) Compras
e) Produção em escala
f) Inspeção
g) Vendas e serviços
h) Auditoria da qualidade

Nesta administração multifuncional temos a formação de um Comitê multifuncional coordenador com as seguintes tarefas:
a) Fixação de metas
b) Planejamento de medidas
c) Planejamento de novos produtos
d) Outros temas importantes 


\subsection{KAIZEN e suas ferramentas}

Também como atividades dos grupos de trabalho o modelo do KAIZEN referido por Imai (1992) cita as tarefas de desdobramento da qualidade, auditoria de plano de ação para verificar metas e ações desdobradas. Atuando dentro dos conceitos do TQM com o enfoque analítico do método tradicional, procurar causas e na seqüência realizar tentativas de se evitar repetição, com o acréscimo do tratamento aos novos produtos, enfoque de projeto com tradução das necessidades dos clientes.

Outra ferramenta dentro do âmbito do KAIZEN seria o TPM, Total Productive Maintenance ou Manutenção Produtiva Total em português, na qual Nakajima (1989) defende o aumento da efetividade dos equipamentos, eliminando suas seis grandes perdas: quebras, set-up e ajustes, perdas de velocidade, pequenas paradas, refugos e retrabalhos e perdas no início de produção.

Adicionando-se ao conceito de que o KAIZEN atua nas melhorias para a eliminação de perdas e desperdícios, se utiliza a ferramenta do SMED - Single Minute Exchange Die, sendo traduzido para troca de ferramentas em um dígito, que seria um processo de redução de tempo de troca de ferramentas (set-up) ou tipo de produto nas máquinas ou linhas de produção (Shingo, 1996)

Imai (1992) indica que um dos frutos das atividades KAIZEN seria a melhoria do relacionamento da mão de obra com a administração, orientando que o operador não pode se deter somente a seu serviço, desenvolvendo todas as suas potencialidades. Pois a mão de obra e administração são aliados dentro da cultura de cooperação instituída pelo KAIZEN. Menciona, ainda, que algumas atividades, como as seguintes, podem ser implementadas para favorecer este ambiente:

- Visita à fábrica de familiares

- Publicidade dirigida à família

- Brindes aos operários

- Menções de desempenho

- Comprometimento entre departamentos

- Festa de boas vindas para funcionários

- Visita às outras fábricas do grupo 
- Informativo da empresa aos jornais e rádio de notícias.

- Mensagens do presidente nos recibos de pagamentos.

- Eventos ao ar livre

- Livro de recordes na fábrica

- Reuniões com a alta gerência

\subsection{Conceito do KAIZEN utilizado neste trabalho}

Neste trabalho será utilizado o conceito apresentado por Imai (1992), no qual o KAIZEN é apresentado como um programa global no qual estão incluídos outras "ferramentas" como a Manutenção Produtiva Total(TPM), a Qualidade Total(TQM), JIT(Just-in-Time), desenvolvimento de produtos e trabalho em equipe. Com aplicações que vão desde a área de operação até a administração, sendo utilizado nas melhorias operacionais e nas relações dentro do âmbito do trabalho.

Há a característica de foco da metodologia nas ações contínuas e direcionadas de modo que o tempo entre a detecção da oportunidade de melhoria e a sua implementação seja o mais curto possível.

Há a necessidade da participação de todos, da alta gerência até o operador de menor qualificação, desta forma, criando um ambiente cultural propenso ao desenvolvimento do KAIZEN. 


\section{METODOLOGIA}

Quando fala-se em pesquisa, busca-se discutir sobre um processo para perguntar e tentar responder questões sobre o mundo (Dane,1990). A pesquisa tem como objetivo principal e último a formulação de questões e encontrar respostas a estas questões, é usada para ordenar as várias teorias e explicações que já existem, como também para apontar respostas.

A determinação do escopo da pesquisa tem que ser feito para evitar erros de análise. Uma maneira de fazer isto é escolher a metodologia de pesquisa que permita dizer quais perguntas são relacionadas e que tipo de resposta se deve buscar porque as questões e respostas referentes a um determinado assunto podem ser variadas.

\subsection{Porque foi escolhida a metodologia do levantamento amostral}

Meredith et al., (1989); Flynn et al.,(1990); Filippini,(1997); Scudder e Hill, (1998) apud Forza (2002) menciona que dados empíricos têm sido usados, vindos da observação levantados na indústria, para suplementar modelos matemáticos e simulações para desenvolver e testar teorias, desde que o Gerenciamento Operacional se tornou um campo funcional de estudos.

A metodologia do levantamento amostral, cujo termo em inglês é conhecido como survey, é usada, entre outras razões, para contribuir para o conhecimento em um campo particular de interesse. Em geral a metodologia envolve uma coleta de dados de indivíduos (através de um questionário endereçado por correio, telefone, entrevistas ou e-mail, etc.) sobre eles mesmos ou sobre uma determinada unidade social a qual eles pertencem (Rossi et al.,1983). A amostragem para o processo de levantamento amostral determina informações sobre uma população grande com um conhecido nível de acuracidade (Rea e Parker, 1992).

A pesquisa do tipo levantamento amostral, como outros tipos de pesquisa de campo, podem contribuir no avanço do conhecimento científico em diferentes 
maneiras (Babbie, 1990; Kerlinger, 1986). Ela pode ser dividida em três tipos: exploratória, confirmatória (Teste de teoria) e descritiva (Pinsonneault e Kraemer,1993; Filippini,1997; Malhotra e Grover, 1998).

No caso deste trabalho, a pesquisa pode ser considerada do tipo exploratória porque o objeto desta seria o de ganhar uma visão preliminar sobre o tópico e fornecer base para um estudo com mais aprofundamento (Forza, 2002). Neste tipo de pesquisa não há um modelo, conceitos de interesse precisam ser melhor entendidos e medidos. Nos estágios iniciais a pesquisa do levantamento amostral do tipo exploratória pode ajudar a determinar o conceito a ser medido em relação ao fenômeno de interesse, como melhor medi-lo e como descobrir novas facetas dele . Poderá também descobrir ou fornecer evidências preliminares da associação entre conceitos. Em nosso caso será determinado como o conceito do KAIZEN pode ser medido em relação à eliminação de perdas na Manufatura e fornecer bases para estudos exploratórios mais aprofundados no futuro, este tipo de pesquisa é o mais apropriado para tal objetivo.

\subsection{Estudos preliminares anteriores ao projeto da pesquisa}

A determinação do modelo teórico é necessária antes do teste de teoria (Dubin, 1978; Sekaran, 1992; Wacker, 1998).

As definições dos construtos devem ser claramente identificadas. As variáveis relevantes devem ser definidas. Devem-se fazer ligações entre os construtos indicando as direções e natureza dos relacionamentos entre eles, explicar porque se espera as observações de relações, ligações com outras teorias (Amundson, 1998) e definir as condições de contorno nas quais se espera encontrar as relações.

No campo do Gerenciamento Operacional não existem, na maioria das vezes, teorias descobertas para serem testadas. Por muitos anos os pesquisadores da área de Gerenciamento Operacional desenvolveram teoria implícita, mas a falta de explicitá-las evitou que estas teorias fossem testadas. Como conseqüência, antes de entrar em pesquisas de teste de teoria, os pesquisadores de Gerenciamento Operacional são obrigados a desenvolver um quadro teórico (Forza, 2002). Este 
desenvolvimento por si só pode ser publicado (como por exemplo, Anderson et al., 1994; Flynn et al., 1994; Forza, 1995).

Ao abordar o tema Metodologia KAIZEN e sua relação com os resultados das empresas e os diversos cenários onde é aplicada, não há uma teoria explícita. Existem alguns estudos empíricos como, por exemplo, o desenvolvido por Brunet e New (2003) no qual se encontrou, no Japão, informações, entre as empresas do ramo de aço e automotivo, sobre um padrão de aplicação da metodologia, resultados e impactos de ordem pessoal. Este estudo concluiu que há uma grande diversidade das práticas encontradas e isto faz com que se continue à procura de idéias de gerenciamento transferíveis, principalmente para replicação em outros ambientes fora do Japão.

Diante deste quadro, na ausência de uma teoria a qual se pode testar, esta pesquisa se fundamentará na contribuição do desenvolvimento de um quadro teórico.

\subsection{Questão a ser respondida}

As proposições colocadas, explanações e condições de contorno são direcionadas com a finalidade de deixar claro qual a principal questão a ser respondida. (Forza,2002).

A grande pergunta que nos leva a proposição principal deste trabalho é: A metodologia KAIZEN aplicada no contexto brasileiro das empresas de Autopeças "funciona"? Ou seja, produz resultado diretamente relacionado ao faturamento destas empresas? Considerando que a resposta a esta questão é afirmativa, em quais condições se obtém sucesso? Este procedimento é apresentado no fluxograma constante da figura 8.

Os limites deste trabalho seriam as indústrias fabricantes de Autopeças que aplicam a metodologia. Este interesse restrito a este grupo de empresas se deve ao fato de que este ambiente industrial sofre uma pressão muito grande por parte de clientes e fornecedores e desde os primeiros anos da década de 1990 se tem notícia de envolvimento destas com a metodologia. 


\section{Ligação ao nível Teórico}

Construto: A Metodologia KAIZEN reduz as perdas na Manufatura

Proposição: A Metodologia KAIZEN produz resultados diretos no faturamento das Empresas que a usam.

Condições de Contorno: Empresas de Autopeças que aplicam a metodologia.

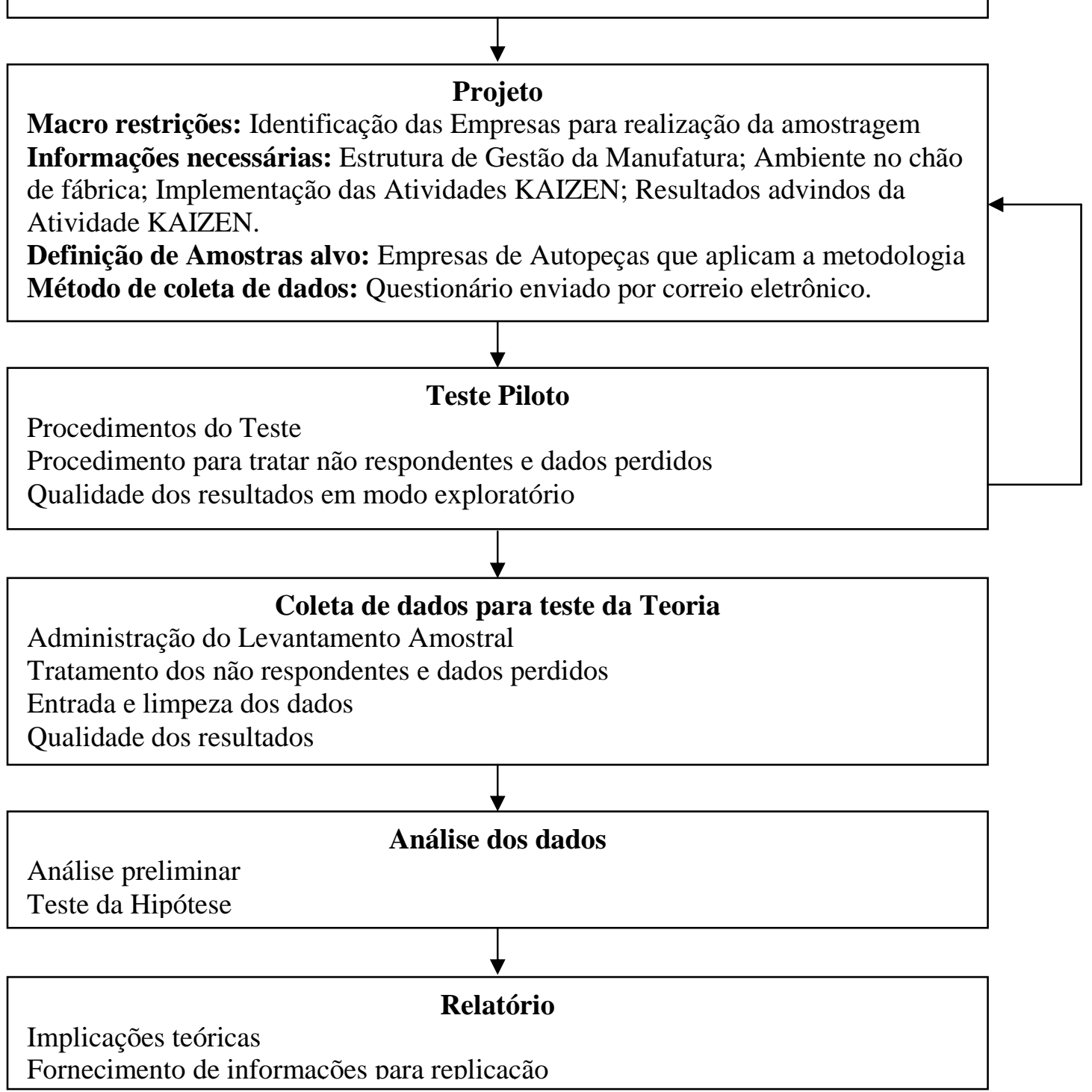

Figura 8 - Teste de Teoria no Processo de Pesquisa tipo levantamento amostra l - Adaptado de Forza (2002) 


\section{PROJETO DO LEVANTAMENTO AMOSTRAL}

\subsection{Preparação do Projeto}

Uma vez que os construtos, suas relações e suas condições de contorno sejam articulados, as proposições que especificam as relações entre os construtos têm que ser traduzidas em hipóteses, relacionando indicadores empíricos.

Antes de se iniciar a coleta de dados é necessário:

- Definir a unidade de análise correspondente ao nível de referência da teoria

- Fornecer e testar as definições operacionais para o construto

- Traduzir a proposição em hipótese

O paralelo empírico do nível de referência da teoria é a unidade de análise. Ela se refere ao nível de dados agregados durante a análise subseqüente. A unidade de análise nos estudos de gerenciamento operacional podem ser indivíduos, grupos, fábricas, divisões, empresas, projetos, sistemas, etc (Flynn et al, 1990).

É necessário determinar a unidade de análise quando são formuladas as questões da pesquisa. Assim, considera-se para este trabalho como unidade de análise as empresas fabricantes de autopeças que aplicam a metodologia KAIZEN.

Os métodos de coleta de dados, tamanho das amostras e mesmo a operacionalização do construto pode algumas vezes ser determinado ou conduzido pelo nível no qual os dados serão agregados no tempo da análise (Sekaran, 1992). Nada sendo feito de modo avançado pode significar que mais tarde as análises apropriadas para o estudo podem não ser feitas. Não é o que acontece na pesquisa relacionada com este trabalho porque os dados e as análises estarão no mesmo nível, não havendo o problema de referência cruzada (Dansereau e Markham, 1997). Se os dados fossem coletados, ou analisados, em um nível de grupo (por exemplo, uma fábrica) e as conclusões fossem levadas ao nível de indivíduo (por exemplo, empregados) se enfrentaria o problema da falácia ecológica (Robinson, 
1950; Babbie, 1990). O nível de referência cruzada torna-se mais importante quando mais que uma unidade de análise é envolvida no estudo (Babbie, 1990).

Mas como transformar os conceitos teóricos em elementos observáveis e mensuráveis? Para a análise dos resultados da aplicação da Metodologia KAIZEN foi considerado que o conceito teórico é multidimensional, assim, para todas as dimensões tem que haver o elemento correspondente na definição operacional. A lista de elementos observáveis que constituem a definição operacional é especificada e observada através dos blocos de questões identificadas no questionário utilizado como instrumento da pesquisa, tornando claro como o construto vai ser observado (Emory e Cooper, 1991).

A ação de redução dos construtos de modo que eles possam ser medidos apresenta vários problemas: alinhamento entre os conceitos teóricos e as medições empíricas, a escolha entre questões objetivas e percentuais, ou a seleção de uma ou mais questões para o mesmo construto. Estes problemas são superados usando definições operacionais que tenham sido desenvolvidas, usadas e testadas. A disponibilidade de tais definições operacionais é bem limitada na área do gerenciamento operacional, com algumas exceções na área de gerenciamento da qualidade (Handfield e Melnyk, 1998). Então se é forçado freqüentemente a desenvolver novas medições: neste caso relatórios de experiências anteriores e sugestões fornecidas no desenvolvimento de medições podem ser aproveitadas (Converse e Presser, 1988; Hinkin, 1995; Hensley, 1999).

Uma das tarefas mais difíceis foi a de traduzir os conceitos teóricos para as definições operacionais, porque elas podem ser diferentes de construto para construto. Alguns construtos conduzem por si só a medições imprecisas, especialmente quando sentimentos das pessoas, atitudes e percepções são envolvidos. Quando construtos como os de satisfação do cliente, têm múltiplas facetas, envolvem percepção ou são planejados para medir através da percepção das pessoas é altamente recomendável usar definições operacionais que incluem elementos múltiplos (Lazarsfeld, 1935; Malhotra e Grover, 1998; Hensley, 1999). Para o construto melhoria no resultado das empresas através da aplicação da metodologia KAIZEN foi planejado haver a avaliação através da percepção das pessoas, desta maneira os elementos múltiplos foram considerados.

O processo de identificar os elementos para inserir na definição operacional (assim como os itens na medição) foi feito através de contatos com elementos da 
população de interesse. Esta ação aconteceu para se ganhar conhecimento prático de como o construto é visto nas organizações reais e identificar a importância específica dentro do tipo de empresas a serem estudadas. Também foi feito o desenvolvimento de itens usando as perspectivas acadêmicas a fim de se ter boas escalas preliminares e manter as revisões de questionário no mínimo.

Depois das definições operacionais terem sido desenvolvidas, elas foram testadas e validadas pelo pessoal de liderança de programas KAIZEN em duas das empresas sob análise. Esta validação da medição do construto pode ser definida como o grau no qual a medição engloba o domínio da definição teórica do construto (Rungtusanatham, 1998). É a extensão na qual a medição captura as diferentes facetas do construto.

Como afirmado por Forza (2002), a hipótese é a conjectura lógica, relacionando duas ou mais variável (medidas), expressadas em forma de afirmações com possibilidade de serem testadas. A hipótese também poderia testar se existem diferenças entre dois grupos (ou entre uma série de grupos) com respeito a qualquer variável ou variáveis. Estas relações são conjeturadas com base na rede de associações estabelecidas no quadro teórico formulado pela pesquisa. A hipótese desta pesquisa é que a Metodologia KAIZEN tem influência na gestão da manufatura, no ambiente do "chão de fábrica" e melhora o resultado operacional da empresa onde é aplicada.

No projeto do levantamento amostral foram feitas todas as atividades que precedem a coleta de dados. Neste estágio foram considerados todos os problemas e dificuldades, procurando encontrar o equilibro entre rigor e possibilidade de realização. Foram planejadas todas as atividades futuras em detalhes, definindo os documentos para manter o rumo das decisões feitas e quais atividades seriam necessárias para prevenir problemas subseqüentes. Foi considerado o quanto ele se ajusta e é possível de ser executado. Não possuindo um modelo bem desenvolvido, consideramos quanto tempo e esforço seriam necessários para desenvolver este modelo, porque poderiam ser restrições ao projeto (Forza,2002).

Como neste tipo de método o tempo e custos devem ser equilibrados, também houve a preocupação de se minimizar os quatro tipos de erros:

- Erro de amostragem - Uma amostra com nenhuma (ou desconhecida) representabilidade sobre a população exclui a possibilidade de generalização. 
- Erro de medição - Dados vindos do uso de medições que não vão de encontro às dimensões teóricas, ou não são confiáveis, fazem qualquer teste sem sentido.

- Erro de conclusão estatística - Quando se está realizando teste estatístico há uma probabilidade de se aceitar uma conclusão que a relação investigada não existe mesmo quando de fato ela existe.

- Erro de validação interna - Quando a explicação dada do que foi observado é menos plausível do que outra qualquer, assim a conclusão pode ser considerada errada.

Para avaliar adequadamente o tamanho das restrições foram identificadas as principais informações necessárias, as quais vêm da hipótese e dos vários propósitos do estudo. Como o estudo requisitou algumas informações consideradas confidenciais pelos respondentes, foi levado em conta que o custo e o tempo para conseguí-las poderia ser provavelmente alto e um número de alternativas do projeto do levantamento amostral poderiam não ser viáveis. O problema também foi o de satisfazer as restrições de tamanho de questionário, foram classificadas as informações por prioridade para ajudar na decisão de uma eventual necessidade de se ajustar a quantidade de perguntas do questionário (Alreck e Settle, 1985; Babbie, 1990).

\subsection{Definição da amostragem}

Antes de ser decidido a respeito da amostra, foi definida a população, elemento da população, quadro da população, amostra, sujeito e amostragem. A População se refere ao inteiro grupo de pessoas, empresas, fábricas ou o que se deseja investigar, no caso seriam as empresas fabricantes de autopeças. Uma única Empresa seria o elemento da população, porque este seria um membro simples da população. $O$ quadro da população seria $O$ das empresas fabricantes de autopeças que aplicam a metodologia KAIZEN, é uma listagem de todos os elementos na população dos quais a amostra foi tirada. Uma amostra é um subconjunto da população, foram considerados como amostra todos os respondentes aos questionários enviados e um sujeito é um membro simples da amostra, uma das 
empresas respondentes. Para a amostragem foi selecionado um número suficiente de elementos de uma população, através do estudo da amostra, e entendimento das propriedades ou características dos sujeitos da amostra, para ser possível generalizar as propriedades ou características dos elementos da população.

O projeto da amostra é muitas vezes deixado em segundo plano nos levantamentos amostrais de Gerenciamento Operacional (Forza e Di Nuzzo, 1998; Rungtusanatham et al., 2001). Muitos artigos não relatam adequadamente como suas amostras foram construídas e não fornecem informações suficientes sobre a amostra resultante. A maioria dos artigos baseados em levantamento amostrais em Gerenciamento Operacional (aproximadamente 88\%) não indica um encaminhamento probabilístico para amostragem (Rungtusanatham et al., 2001). Uma das dificuldades deste Projeto foi 0 de se conseguir uma amostragem adequada, pois projetos pobres de amostragem podem restringir a aplicação de técnicas estatísticas mais apropriadas e generalizar os resultados. Dois itens foram reforçados: aleatoriedade e tamanho da amostra. Aleatoriedade é associada com a habilidade de uma amostra representar a população de interesse. Tamanho da amostra é associado com os requerimentos dos procedimentos estatísticos usados para medir a qualidade da pesquisa e do teste de hipótese.

Como quadro da população deve ser tirado dos recursos disponíveis mais amplos para facilitar a replicação do estudo. Foi utilizada a classificação do tipo de indústria, fabricantes de autopeças que aplicam a metodologia KAIZEN, porque é um importante aspecto de enquadramento da população. "Controlar os efeitos do tipo de indústria pode compensar a variabilidade entre tipos de indústrias, em termos de tipo de processo, gerenciamento da força de trabalho, forças competitivas, grau de sindicalização, etc"(Flynn et al., 1990)

Há outros meios justificáveis de escolha de amostra, baseada em aspectos específicos ( por exemplo processo tecnológico comum, posição na cadeia de fornecimento, etc.) a qual deve ser controlada para investigação do fenômeno sob estudo. Outra variável importante que foi controlada foi o tamanho da empresa, definido através do número de funcionários porque é uma informação facilmente disponível que pode ser incorporada no processo de seleção da amostra.

Para o projeto da amostra, foi levado em consideração que estas podem ser agrupadas em duas famílias: probabilística e não probabilística. Na amostragem probabilística os elementos da população têm alguma probabilidade de serem 
selecionados, diferentemente da amostragem não probabilística. A amostragem probabilística é usada para assegurar a representatividade da amostra, quando se está interessado em generalização dos resultados. Mas, como o tempo e outros fatores, como a dependência de recebimento das respostas aos questionários enviados ser um fator fora de controle, prevaleceram sobre as considerações de generalização, a amostragem não probabilística foi a definida.

Tendo a população relacionada a esta pesquisa já definida como fabricantes de autopeças e o quadro da população definido como sendo empresas que aplicam a metodologia KAIZEN, não foi considerado a realização da amostragem aleatória estratificada.

O tamanho da amostra foi outra preocupação. Para a perfeita avaliação e especificação da qualidade da amostra foram utilizados os dados tirados da apresentação do Sindipeças (2006) e listas de empresas que aplicam a metodologia KAIZEN fornecidas por consultores especializados. É um item complexo o qual é ligado ao nível de significância, ao poder estatístico do teste e também ao tamanho da relação pesquisada.

Os dados poderiam ser coletados em vários modos, em diferentes conjuntos, e de diferentes fontes. Como a pesquisa deste trabalho é do tipo levantamento amostral, os métodos que poderiam ser usados seriam as entrevistas e questionários. Para as entrevistas estas poderiam ser estruturadas e não estruturadas. Poderiam ser conduzidas tanto frente a frente quanto por telefone. Os questionários poderiam ser administrados pessoalmente, por telefone, por correio ou correio eletrônico (e-mail), podendo usar o telefone para melhorar a taxa de respostas aos questionários enviados.

Cada método de coleta de dados tem méritos assim como também problemas. A decisão sobre a seleção do método foi feita baseada na necessidade da pesquisa por causa das restrições de tempo e recursos. Foi então decidido que o método a ser utilizado seria o de envio de questionário anexado a uma mensagem de correio eletrônico (e-mail), utilizando-se do contato telefônico anterior ao envio, a fim de se conseguir um índice de respostas maior.

A seleção foi feita baseada nos seguintes conceitos dos métodos de envio:

- Levantamento amostral pelo correio - Os questionários são impressos e enviados pelo correio. Pede-se aos respondentes para completar os questionários por si próprios e enviá-los de volta. Os 
questionários enviados por correio têm as seguintes vantagens: redução de custos; podem ser completados na conveniência do respondente; não há restrição de tempo; eles podem ser preparados para dar uma impressão de autoridade; o anonimato pode ser assegurado; podem reduzir a influência do entrevistador. Por outro lado, os questionários enviados por correio têm baixo índice de resposta, quando se compara a outros métodos, demoram e são mais afetados pela auto seleção, falta de envolvimento do entrevistador e falta de questões abertas.

- Levantamento amostral face a face - $O$ entrevistador solicita informações diretamente do respondente em uma entrevista pessoal. As vantagens são: flexibilidade em seqüenciar a entrevista, detalhes e explicações; uma oportunidade para administrar questionários complexos; melhorar a habilidade de encontrar pessoas difíceis de serem achadas. Algumas desvantagens seriam: alto custo; desvios causados pelo entrevistador; relutância do entrevistado a cooperar; maior tensão entre entrevistador e entrevistado, menor anonimato.

- Levantamento amostral por telefone - As informações são colhidas por uma entrevista através em uma chamada telefônica. A vantagem seria a rápida coleta de dados, menor custo, anonimato, facilidade de acesso e segurança de que as instruções estão sendo seguidas. As desvantagens são o menor controle sobre a situação de entrevista, menor credibilidade e falta de materiais visuais.

- Levantamento amostral por correio eletrônico - Os questionários são enviados anexados a uma mensagem de correio eletrônico ou se convida o respondente a visitar um determinado web site na Internet para responder o questionário. A vantagem seria um mínimo custo comparado com outros meio de distribuição, mas problemas podem ocorrer relacionados à amostragem e controle do ambiente de pesquisa (Birnbaum, 1999). 


\subsection{Desenvolvimento do Questionário}

A principal característica do levantamento amostral é que precisa de um instrumento estruturado de coleta de informações. Quando foi definido o conteúdo daquilo que seria medido ou observado com a pesquisa, algumas tarefas foram desenvolvidas para confecção do questionário:

- Organização da maneira que as perguntas seriam feitas para se obter as informações conceituais específicas.

- Definição da escala a ser utilizada

- Definição dos respondentes apropriados

- Posicionamento das questões no questionário de forma que se facilitassem e motivassem as respostas.

Malhotra (2001) apud Caminada (2006) observa que não há princípios científicos para desenvolvimento de um bom questionário, seria algo que se adquire com a experiência. Mas existem alguns pontos que devem se seguidos, por exemplo, o máximo de 50 perguntas, procurando ser mais curto possível se evita que haja uma perda de interesse em responder ao questionário por ficar cansativo, mesmo que, a princípio, haja o interesse do respondente (Albrecht e Bradford,1992).

Importante responder a algumas questões iniciais antes do desenvolvimento do questionário, a fim de se visualizar de forma geral o questionário que se pretende fazer, ou que precisa ser feito para se atingir as necessidades da pesquisa, assim, delineá-lo de forma bem estruturada, as questões seriam:

1. Quem deseja a informação?

Administradores interessados em referências de atuação em busca de maior eficiência em suas atividades e também a pesquisadores do tema KAIZEN.

2. O que se está tentando conseguir?

Referências da atividade KAIZEN no Brasil

3. Quem tem a informação que se procura?

Gerentes de Produção, Gerentes de Manutenção, Responsáveis por "Melhoria Contínua", Gerentes Industriais, etc, de empresas que utilizam KAIZEN.

4. Como a pesquisa pode contribuir para o propósito? 
A Análise Amostral (Survey) apresentará exemplos e conjuntos de dados das atividades e resultados da implementação da Metodologia KAIZEN em Indústrias de autopeças de médio porte no Brasil.

Levando-se em consideração que o questionário seria enviado por correio eletrônico, ele foi projetado baseado nos conceitos colocados por Forza (2002):

- Linguagem - Se a questão não é entendida ou é mal interpretada, a resposta obtida não seria confiável. Outra escolha a ser feita seria sobre se as questões seriam abertas ou fechadas. As questões fechadas facilitam a tabulação das respostas, mas se deve ter o cuidado de que as questões sejam mutuamente exclusivas e que coletivamente abordem o tema todo. Outra preocupação seria a de balancear palavras negativas e positivas nas questões para evitar que o respondente mecanicamente as responda. Outras coisas a serem evitadas seriam os direcionamentos propositais às respostas desejadas, questões dúbias, questões muito grande e emocionalmente carregadas.

- Escala - A escolha da escala depende de se facilitar a resposta e análise.

Aguiar (1998) cita que escala Likert é a mais usada, consiste em pedir maior ou menor concordância dentro de cinco respostas possíveis. $O$ respondente concorda ou discorda numa escala de 1 a 5 . Nesta pesquisa, a fim de prevenir a possibilidade de uma concentração na posição central optou-se pelo número par de alternativas. Conforme Hill e Hill (1998), muitos respondentes diante de um número ímpar de alternativas buscam a posição central da escala, adotando uma posição conservadora quando na maioria das vezes têm uma têm uma posição mais forte a respeito. Por outro lado, alternativas em número par obrigam os respondentes a dar uma opinião definitiva, positiva ou negativa.

No questionário elaborado para se buscar as respostas a esta pesquisa, também, as alternativas são em maioria opções de medida de dispersão sobre a ocorrência do assunto questionado.

- Identificação do Respondente - As unidades de análises seriam as empresas, mas estas não respondem às questões, são necessárias as pessoas. Para o tipo de respostas necessárias à pesquisa foram identificadas as pessoas que ocupam os cargos de Diretores/Gerentes Industriais ou responsáveis por programa de melhoria contínua. 
- Regras de projeto do Questionário - Foram seguidas algumas regras para a confecção do questionário, tais como uma introdução adequada, instruções para respostas, e preocupação de não deixá-lo muito longo.

\subsection{Encaminhamento junto às Empresas e Respondentes}

Para aumentar a possibilidade de se obter uma boa resposta ao questionário, foi tomado o cuidado de planejar a execução do levantamento amostral e fornecer instruções detalhadas sobre como as unidades amostradas vão ser contatadas e como o questionário vai ser administrado. Foi procurado encontrar maneiras de se obter a colaboração das empresas e respondentes. Conforme Dillman (1978), a resposta ao questionário deve ser vista como uma troca social e sugere que:

- Recompensar o respondente de alguma forma positiva, uma maneira encontrada foi o de garantir o anonimato e de seria enviada uma cópia da dissertação quando esta fosse terminada.

- Preocupação em reduzir os custos para o respondente fazendo com a tarefa de responder ao questionário seja breve, eliminando situações embaraçosas.

- Estabelecimento de um ambiente de confiança antecipadamente através de conhecimento prévio da empresa em questão e de um contato telefônico anterior ao envio do questionário.

Uma dificuldade que existe neste tipo de pesquisa é o de identificar a pessoa certa para receber e responder o questionário, para isto foi buscado, junto a diversas consultorias que trabalham com a implementação do KAIZEN, por contatos específicos dentro das empresas, fazendo com que houvesse uma diminuição do risco de não se atingir o respondente adequado para a pesquisa.

\subsection{Teste Piloto}

Assim que o questionário ficou pronto e da mesma forma a identificação das unidades de análise, houve a necessidade de verificar se as propriedades do 
questionário e a viabilidade da administração do levantamento amostral. Para testar o que foi projetado foi passado o questionário para um colega de atividade, um consultor da área e um dirigente industrial. $O$ papel do colega seria verificar se 0 questionário estava de acordo com os objetivos do estudo. O papel do consultor foi o de prevenir alguma questão óbvia demais e o papel do dirigente foi o de fornecer retorno daquilo que poderia afetar as respostas do questionário. Foi solicitado às pessoas que tiveram os primeiros contatos com o questionário que verificassem se:

- As instruções estavam claras

- As questões estavam claras.

- Houve algum problema no entendimento das perguntas.

- O tema em estudo foi bem coberto pelas questões.

Com o retorno dos questionários foi avaliado:

- Se as respostas foram muito concentradas, se foram muito diferentes das esperadas ou se as questões estão adequadas ao tipo de empresas direcionadas.

O retorno foi bastante positivo, comentários confirmaram o adequado entendimento e adequação da abrangência das questões em relação à finalidade da pesquisa. Foram feitas pequenas modificações no texto e acréscimo de mais informações nas instruções do questionário de acordo com o retorno. Em algumas questões não estava claro se havia a possibilidade de se assinalar mais de uma alternativa e isto foi identificado a tempo de ser corrigido.

Com relação às respostas recebidas não houve nenhum problema que necessitasse alteração do questionário.

\subsection{Análise da amostragem}

Com a finalidade de se obter contatos diretos para o envio do questionário, primeiramente foi buscada a aproximação com diversas consultorias especializadas na aplicação da metodologia KAIZEN. Além disto, foi utilizada a lista de associados do Sindipeças divulgada no local desta entidade na Internet como fonte confiável de onde se pudesse extrair o nome das empresas do ramo alvo desta pesquisa. 
Através do cruzamento das informações foram selecionadas as empresas que seriam enviadas os questionários.

O objetivo foi o de enviar os questionários exclusivamente para as empresas que aplicam a metodologia KAIZEN dentro das indústrias de autopeças. Com as informações das principais consultorias que atuam no desenvolvimento de projetos KAIZEN nas empresas e as informações do Sindipeças, foram obtidos os contatos de 58 empresas, que seriam o alvo para o envio dos questionários. Foram enviados, também, 30 questionários para empresas fora do mercado de autopeças, para se verificar e discutir, caso houvesse necessidade, se as respostas recebidas teriam um perfil diferente.

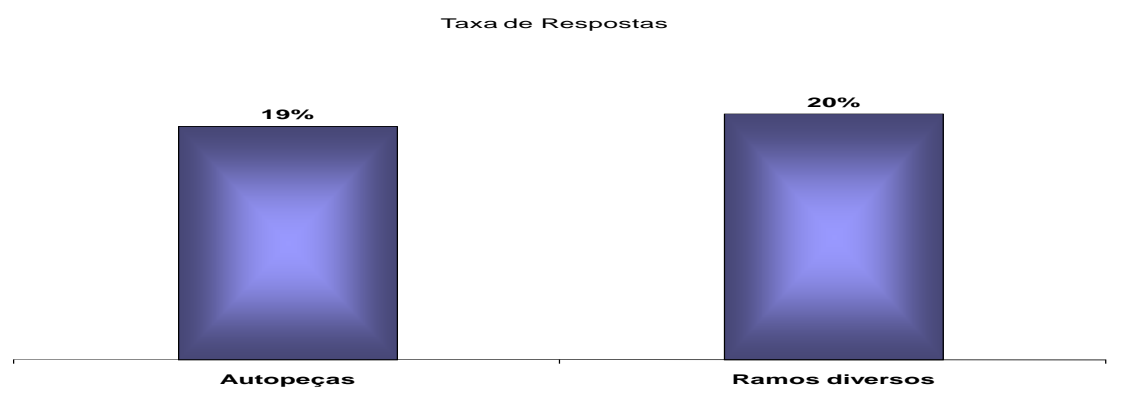

Figura 9 - Índice de retorno de respostas

Foram feitos contatos telefônicos antes do envio do questionário, via e-mail, diretamente ao profissional da empresa selecionada. Os contatos, envios, controle e acompanhamento do questionário foram realizados pessoalmente. A figura 9 resume o perfil da amostra e da porcentagem de retorno dos questionários.

Foram recebidos 11 questionários respondidos provenientes das empresas de autopeças, $19 \%$ dos questionários enviados e 6 de outros ramos industriais, 20\% dos questionários enviados. A amostra é composta então de 11 empresas fabricantes de autopeças. Analisar a representatividade da amostra se refere à inferência do tamanho da população. Não se sabe exatamente quantas empresas ativas compõem o ramo dos fabricantes de autopeças e, dentro destes ramos, quantas aplicam a metodologia KAIZEN. Contudo, os dados divulgados pelo Sindipeças (2006) e as informações das Consultorias permitem boa aproximação e, por isso, são usados nesta pesquisa como referência para os fins de estimar a população dos fornecedores da cadeia e comparar com os resultados obtidos. Assim, o número de respondentes da amostra de $19 \%$ da população estimada é um número que está praticamente no limite mínimo de $20 \%$ de taxa de respostas, segundo Malhotra e Grover(1998) para uma boa representatividade. 
Pesquisas em geral na área de Gerenciamento Operacional tendem a depender de amostras pequenas (Forza, 2002), e o mesmo acontece com esta pesquisa, assim é importante verificar a credibilidade da amostra disponível. Sudman (1983) nos fornece uma escala (Tabela 2) para avaliar a credibilidade de uma amostra pequena . Na faixa [-8...5] a credibilidade do levantamento amostral é muito pobre, [6...15] credibilidade limitada, [16...25] boa credibilidade e [26...35] muito boa credibilidade . Esta pontuação é originada de um julgamento qualitativo, não se tratando de uma avaliação quantitativa, há certa arbitrariedade, mas é uma forma consistente de discriminar entre diferentes níveis de credibilidade de amostras.

Atrás desta pontuação estão algumas características. Normalmente uma amostra tomada em uma área geográfica limitada representa menos uma população do que amostra tirada de múltiplas locações. Pesquisas que discutem problemas de viés têm mais credibilidade do que aquelas que não fazem isto. $O$ uso de populações especiais em alguns casos é uma ferramenta poderosa para testar a teoria, mas se usada por conveniência pode levar a erros.

Tabela 2 - Escala de credibilidade para amostras pequenas. Adaptado de Sudman (1993)

\begin{tabular}{ll}
\hline Característica & Pontuação \\
\hline Abrangência & Locação única(0), Locações limitadas geograficamente (4), \\
Geográfica & Grande abrangência (6), Totalidade universal (10) \\
\hline $\begin{array}{l}\text { Discussão das } \\
\text { limitações }\end{array}$ & Nenhuma discussão (0), discussão breve (3), discussão \\
\hline Uso de & Detalhada (5) \\
populações & (-5), uso por conveniência sem vieses óbvios (0), necessário \\
especiais & para testar teoria (5), população geral (5). \\
\hline Tamanho da & Muito pequena para análise significativa (0), adequada para \\
amostra & alguns trabalhos mas não para maiores análises (3), \\
\hline Execução da & adequada para o propósito do estudo (5) \\
amostragem & $\begin{array}{l}\text { evidência de descuido no trabalho de campo (3), taxa } \\
\text { razoável de respostas e operações de campo controladas (5). }\end{array}$ \\
\hline Uso de recursos & $\begin{array}{l}\text { Recursos escassos (0), bom uso dos recursos (3), uso ótimo } \\
\text { dos recursos (5) }\end{array}$ \\
\hline Faixa de pontos & [-5\} a [35] \\
\hline
\end{tabular}


É possível que tamanhos de amostras sejam satisfatórios quando consideradas na totalidade, mas não o são quando quebradas em sub-amostras para análises mais detalhadas. Quando a taxa de respostas é pequena é comum a introdução de vieses pela auto-seleção de respondentes. Algumas vezes o pesquisador é pressionado pelo cronograma, pelos custos ou recursos. Mesmo nestes casos alguns projetos de amostragem são mais efetivos no uso de recursos disponíveis que outros.

Utilizando a escala de credibilidade para análise da amostra desta pesquisa temos:

- Abrangência geográfica - Não houve restrição geográfica quando do envio dos questionários. Claro que as empresas respondentes estão no eixo sul-sudeste do país, mas isto é uma questão de concentração da atividade industrial por aqui. Desta forma consideramos que a abrangência foi grande e conseqüentemente foi atribuída a pontuação 6.

- Discussão das limitações - Não houve discussão sobre as limitações da amostra, pontuação 0 .

- Uso de populações especiais - No caso desta pesquisa a população é especial porque houve o critério de que as empresas desta população tivessem a prática do KAIZEN em sua manufatura. Mas este fato foi uma necessidade para se testar a teoria. Portanto a pontuação atribuída foi de 5 .

- Tamanho da amostra - Considerada adequada para o estudo conforme já discutido, está praticamente no limite mínimo de $20 \%$ de taxa de respostas segundo Malhotra e Grover(1998) para uma boa representatividade, portanto pontuação atribuída 5.

- Execução da amostragem - Foi considerado que poderia ter havido um trabalho de campo mais cuidadoso, no sentido de se obter uma taxa de respostas maior, fazendo um acompanhamento mais rigoroso junto às pessoas as quais foram enviados os questionários. Pontuação atribuída 3.

- Uso dos recursos - Foi considerado um recurso o meio pelo qual se obteriam dados para esta pesquisa. Desta forma os recursos tiveram 
bom uso, porque foram utilizados os recursos de correio eletrônico, contatos telefônicos e correio. Assim, a pontuação atribuída é de 3 .

Concluindo, a pontuação total foi de $22 \mathrm{e}$, de acordo com a classificação para credibilidade para amostras pequenas de Sudman (1983), quando a pontuação total fica entre 16 e 25 é considerado que a amostra tem boa credibilidade.

As figuras 10 e 11 ilustram a distribuição das empresas respondentes no que se refere ao porte destas empresas de acordo com o padrão adotado pelo SEBRAE e as figuras 12 e 13 a distribuição do número de funcionários conforme critério do Sindipeças.

Autopeças - Distribuição por Porte da Empresa*

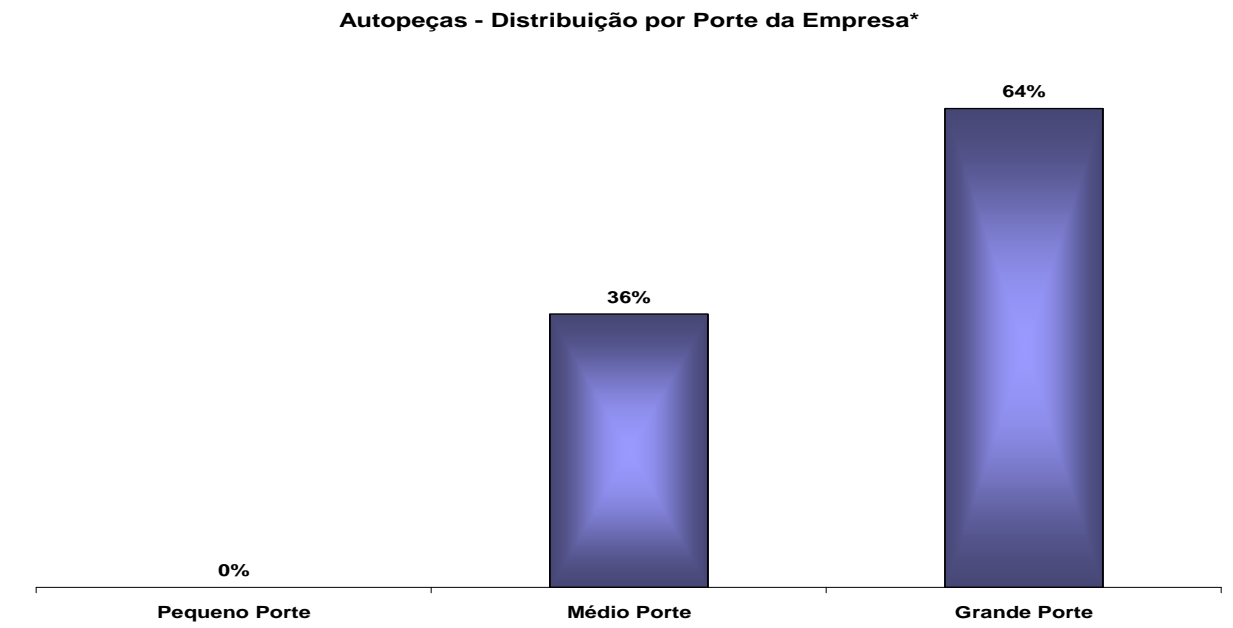

Figura 10 - Distribuição dos respondentes do ramo de Autopeças por porte da empresa conforme SEBRAE

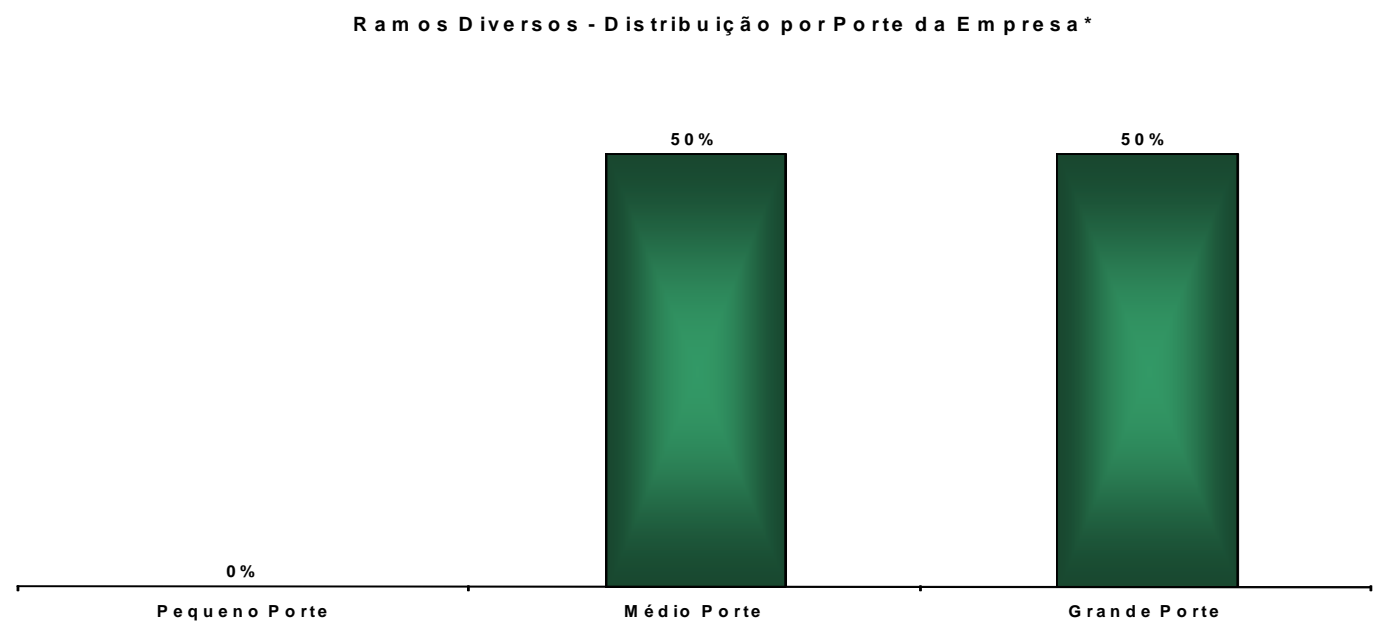

Figura 11 - Distribuição dos respondentes de ramos industriais diversos por porte da empresa conforme SEBRAE 
Autopeças - Distribuição por Número de Funcionários

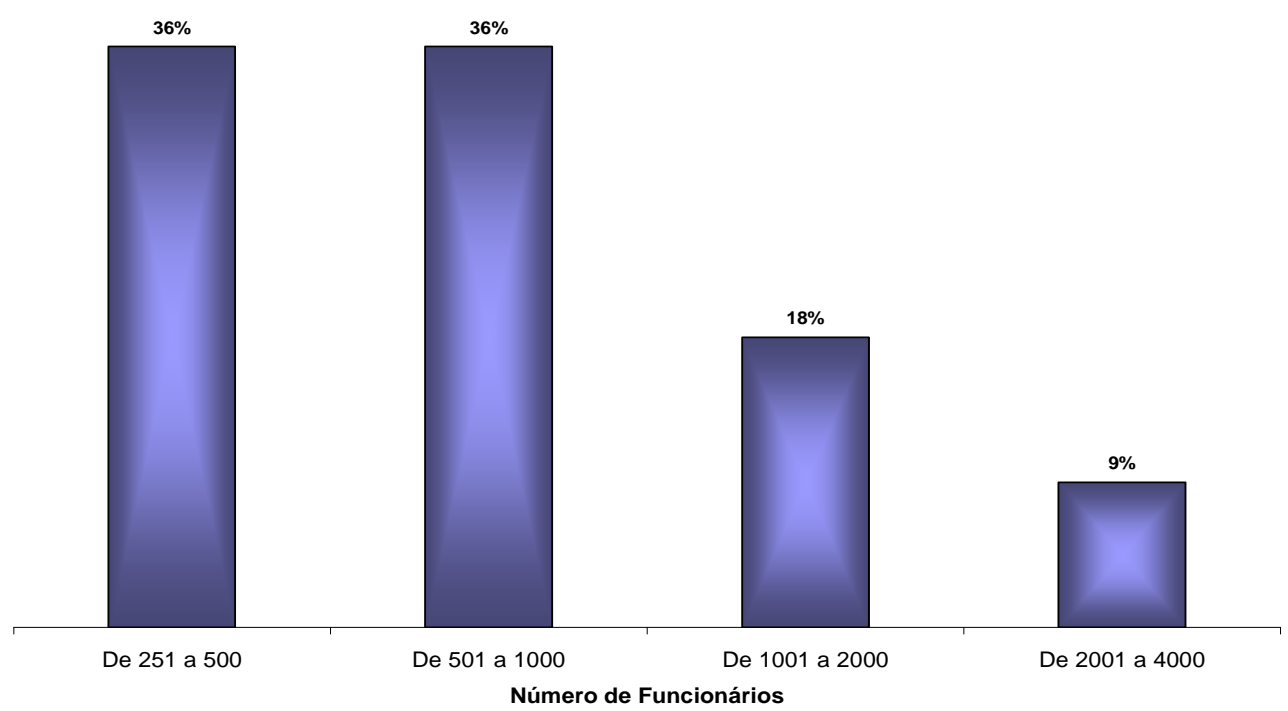

Figura 12 - Distribuição dos respondentes do ramo de autopeças por número de funcionários conforme Sindipeças

Ramos Diversos - Distribuição por Número de Funcionários

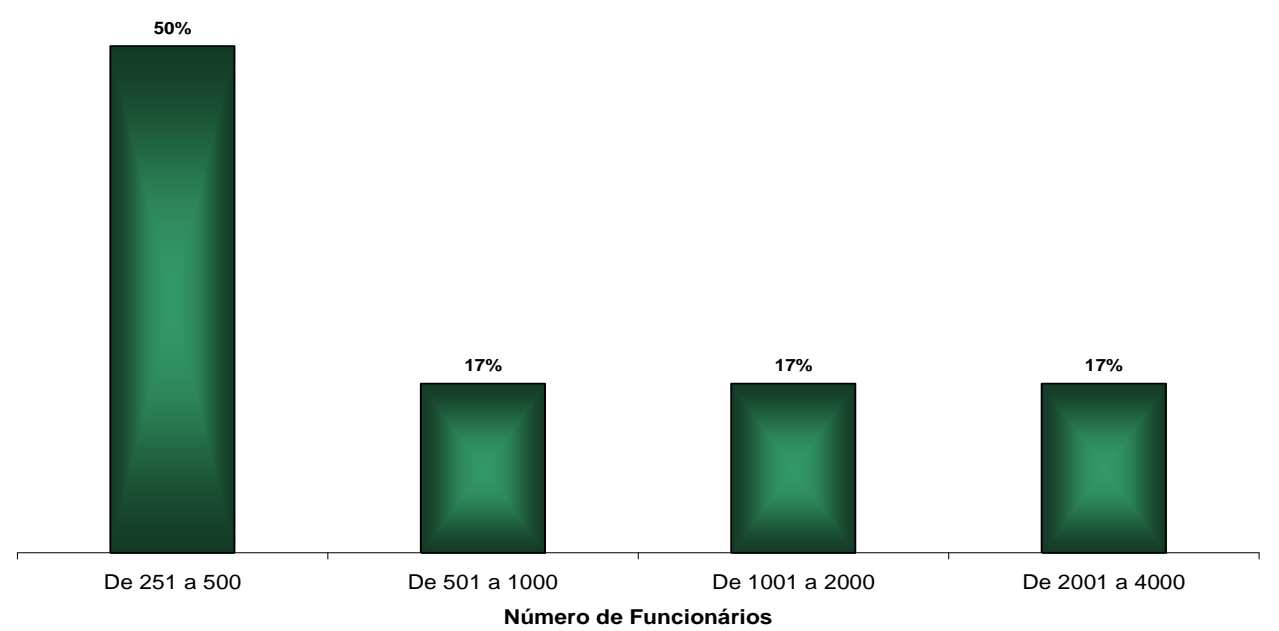

Figura 13 - Distribuição dos respondentes do ramos industriais diversos por número de funcionários conforme Sindipeças

Esta proporção aponta para uma concentração maior de respondentes de empresas fabricantes de autopeças com até 1000 funcionários (72\%) e, de acordo com o critério do SEBRAE, a maior parte é considerada de grande porte (64\%). Entre as empresas respondentes de ramos industriais diversos, a maior 
concentração de respondentes está nas empresas de até 500 funcionários e igualmente divididas na classificação relacionada ao porte.

Com relação à origem de capital, a maior parte tanto nas empresas fabricantes de autopeças (82\%) como nas empresas de ramos industriais diversos (83\%), é estrangeira (figura 14).
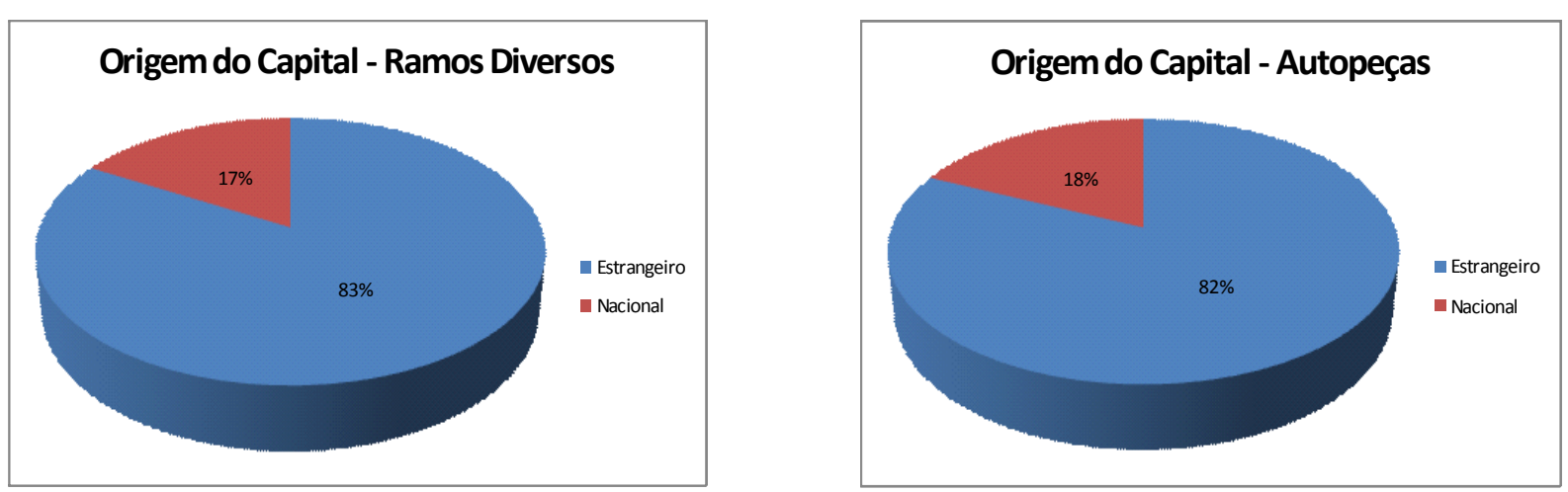

Figura 14 - Distribuição dos respondentes conforme origem do capital das empresas.

É importante mencionar a diversidade de tipos de produtos representada pelas empresas respondentes. Mesmo para aqueles classificados como autopeças, na tabela 3 pode se verificar que há uma abrangência grande de processos em virtude da diferença entre os produtos, também nesta tabela deve-se observar a totalidade do número de unidades no Brasil referentes às empresas respondentes.

$\mathrm{Na}$ seqüência do trabalho é apresentado o questionário que foi distribuído, comentado de acordo com as subdivisões feitas em blocos conforme as informações necessárias à pesquisa. 
Tabela 3 - Principais produtos das empresas respondentes.

\begin{tabular}{|c|c|c|c|c|c|c|}
\hline & Empresa & $\begin{array}{l}\text { Número de } \\
\text { Funcionários }\end{array}$ & $\begin{array}{c}\text { Origem do } \\
\text { Capital }\end{array}$ & Ramo & $\begin{array}{l}\text { Principal } \\
\text { Produto }\end{array}$ & $\begin{array}{l}\text { Unidades } \\
\text { no Brasil }\end{array}$ \\
\hline \multirow{12}{*}{ Autopeças } & A & 350 & Estrangeiro & Auto peças & $\begin{array}{l}\text { Sistemas de } \\
\text { injeção de } \\
\text { Combustível }\end{array}$ & 11 \\
\hline & B & 450 & Estrangeiro & Auto peças & Compressores & 1 \\
\hline & C & 330 & Estrangeiro & Auto peças & Parafusos & 1 \\
\hline & $\mathrm{D}$ & 1200 & Estrangeiro & Auto peças & Baterias & 6 \\
\hline & $E$ & 900 & Estrangeiro & Auto peças & $\begin{array}{l}\text { Produtos de } \\
\text { borracha }\end{array}$ & 3 \\
\hline & $\mathrm{F}$ & 900 & Estrangeiro & Auto peças & Vidros & 5 \\
\hline & G & 1000 & Nacional & Auto peças & $\begin{array}{l}\text { Usinagem de } \\
\text { metais }\end{array}$ & 2 \\
\hline & $\mathrm{H}$ & 3000 & Estrangeiro & Auto peças & Transmissões & 3 \\
\hline & 1 & 340 & Nacional & Auto peças & $\begin{array}{l}\text { Bombas de } \\
\text { óleo e água }\end{array}$ & 1 \\
\hline & $\mathrm{J}$ & 1000 & Estrangeiro & Auto peças & Filtros & 1 \\
\hline & L & 2000 & Estrangeiro & Auto peças & Pneus & 2 \\
\hline & & & & & Total & 36 \\
\hline \multirow{6}{*}{$\begin{array}{l}\text { Outros } \\
\text { Segmentos } \\
\text { Industriais }\end{array}$} & M & 260 & Estrangeiro & Farmaceutico & Arcóxia & 1 \\
\hline & $\mathrm{N}$ & 1200 & Estrangeiro & Alimentos & Alimentos & 27 \\
\hline & 0 & 2200 & Nacional & Alimentos & Óleo de soja & 8 \\
\hline & $P$ & 650 & Estrangeiro & Embalagem & $\begin{array}{l}\text { Embalagens } \\
\text { Plásticas }\end{array}$ & 1 \\
\hline & Q & 270 & Estrangeiro & Químico & Detergente & 4 \\
\hline & $\mathrm{R}$ & 440 & Estrangeiro & Metalúrgico & Medidores & 1 \\
\hline
\end{tabular}




\section{QUESTIONÁRIO COMENTADO}

O questionário foi dividido em 6 blocos com a finalidade de melhor distribuir os pontos de interesse da pesquisa. Os quais são:

A- Identificação da Empresa: Neste bloco o respondente foi solicitado a colocar informações sobre o principal produto da empresa, qual país de origem da empresa, número de funcionários e número de unidades no Brasil.

B- Estrutura de Gestão da Manufatura: Neste bloco, o conjunto de perguntas tem como finalidade identificar em qual estágio de desenvolvimento, em relação ao conceito de melhoria contínua no chão de fábrica, está a empresa pesquisada.

São oito questões direcionadas para avaliar se os conceitos ligados ao KAIZEN estão em uso e o quanto eles estão absorvidos no dia a dia da empresa.

- A primeira pergunta deste bloco é o quanto o conceito de valor agregado e valor não agregado estão estabelecidos na Empresa. Quanto mais estes conceitos existirem de forma consistente mais fácil para empresa se concentrar na eliminação ou redução daquilo que não agrega valor e focar na melhoria das atividades que realmente agregam valor ao produto ou serviço prestado pela empresa.

- Sua Organização tem realizado iniciativas estruturadas para melhoria de produtividade? Questão que verifica quais ações estruturadas se está tomando em direção à melhoria de produtividade na empresa, também uma forma indireta de verificar se o conceito de produtividade está em uso nesta empresa.

- Qual o nível de barreiras que você identifica para as iniciativas de melhoria na Manufatura? Nesta questão se procura saber o quanto a "cultura" da empresa facilita ou não o conceito e atividades de melhoria contínua.

- Quantas áreas de manufatura foram mapeadas em relação ao fluxo de valor (Value Stream Map)? O mapeamento do fluxo do valor é uma ferramenta usada para, como o nome menciona, mapear o fluxo de valor na empresa e identificar as oportunidades de ganhos. Quanto 
mais a empresa for mapeada maior será o conhecimento a respeito de suas dificuldades e perdas, tornando a atividade de melhoria mais eficaz.

- O ambiente da Manufatura é aberto para mudanças? Através desta pergunta se procura medir o quanto aberta às mudanças é a área de manufatura, porque o KAIZEN se pressupõe mais eficaz em ambientes abertos às mudanças.

- Existe alguma política para alinhamento da cadeia de fornecimento em relação às propostas de gestão da manufatura? Nesta pergunta a intenção é a de saber se existe uma extensão, aos fornecedores, dos programas internos de gestão. Questão relevante para avaliar a profundidade dos programas de melhoria da empresa.

- A introdução de novas tecnologias leva em consideração a redução das perdas de Manufatura? Em muitas oportunidades as políticas de inovação são descasadas das atividades da gestão da manufatura, nesta questão se verifica se há este tipo de ocorrência na empresa pesquisada ou se há uma integração entre a inovação tecnológica e a manufatura.

- Há uma consideração em relação à redução dos estoques? Segundo Ohno (1988) uma das perdas na manufatura é o excesso de estoques. Nesta questão se procura saber o quanto este tipo de perda é considerado na empresa em questão.

- Na última questão deste bloco busca-se informações sobre a política de desenvolvimento de pessoal na empresa, porque um dos principais pontos questionados pelos críticos aos sistemas de gestão que buscam a eliminação das perdas da manufatura é a desconsideração do fator humano (Forrester, 1995).

C- Ambiente no chão de fábrica: Neste bloco do questionário houve a preocupação de se dar ênfase ao "chão de fábrica" no que se refere a como é a cultura deste ambiente em relação ao trabalho em equipe e participação da liderança nas iniciativas.

- A primeira pergunta deste bloco é se a liderança do chão de fábrica conduz atividades ou iniciativas de melhorias. Esta pergunta tem a 
finalidade de saber qual o grau de participação da liderança nas iniciativas de melhoria do chão de fábrica.

- Nesta pergunta o interesse é o de saber se houve algum envolvimento de consultoria para algum tipo de atividade de melhoria no chão de fábrica. Esta questão é importante porque nos mostra a forma como a metodologia foi introduzida na empresa, com isto poderemos traçar um paralelo entre o tipo de inserção da metodologia e o grau de sucesso do empreendimento.

- Um importante fator para que haja verdadeiras mudanças através da metodologia KAIZEN é a participação efetiva dos operadores nos trabalhos, e é esta posição na empresa pesquisada que trata este questionamento, se nas atividades de melhoria do chão de fábrica há a participação efetiva dos Operadores.

- Observa-se em muitos empreendimentos voltados para a melhoria contínua que não há continuidade e isto é o que se procura saber com a questão sobre se as atividades de melhorias no chão de fábrica têm continuidade na empresa pesquisada.

- Os operadores sabem a diferença entre atividades que agregam valor e aquelas que não agregam valor? Sabem quais as decisões para se evitar as perdas? $\mathrm{Na}$ questão "O conhecimento básico nos conceitos da eliminação das perdas, por parte dos Operadores é..." a intenção é saber se o conhecimento nestes pontos existe no chão de fábrica entre os operadores.

- Uma das bases para o desenvolvimento do KAIZEN é a existência de trabalhos em times de melhoria, para resolução de problemas ou avaliação de resultados e direcionamento de estratégias, este o alvo da pergunta se "Há grupos multifuncionais com capacidade para desdobramentos e tomadas de decisão?"

- Na pergunta "A capacidade da Liderança para lidar com as variações de demanda é..." o alvo é o pessoal de liderança do chão de fábrica e as variações inerentes a um sistema de produção flexível. Eles estariam preparados para apoiar os operadores no que for preciso 
para atender a demanda aos seus produtos?Eles têm padronização e treinam os operadores com base nestes padrões?

- Com o advento do KAIZEN há um processo gradual mais contínuo de mudanças e para isto o sistema de gestão deve estar preparado para os diversos cenários que vão surgindo a medida que o processo avança, esta é a razão de ser da pergunta: A gestão da Manufatura contempla os diversos ambientes resultantes dos processos de mudança?

- Novamente o fator humano é questionado através da pergunta sobre se os critérios de competência, conhecimento e habilidades estão definidos para os cargos de chão de fábrica. É importante que critérios mencionados sejam implantados para que não se perca o quesito humano nos trabalhos de redução de perdas (Forrester, 1995).

D- Implementação de Atividades KAIZEN, as questões deste bloco foram direcionadas para o entendimento dos trabalhos de implementação do KAIZEN na empresa pesquisada. Houve o pressuposto de que havia a metodologia na empresa em questão, pois este foi um dos critérios de seleção das empresas para envio do questionário.

- Para conhecer qual o grau de organização do KAIZEN nas atividades da empresa a primeira questão deste bloco questiona se as atividades KAIZEN são organizadas estruturadamente.

- Para iniciar um trabalho da magnitude de um programa KAIZEN deve haver pelo menos um fator preponderante para início desta jornada, qual foi a motivação para se iniciar trabalhos de KAIZEN? Este é o tema da questão sobre o que motivou a Empresa a iniciar as atividades KAIZEN?

- Nos ambientes em que se iniciam as atividades do KAIZEN há sempre um setor da empresa ou um mentor para início das atividades. Para se conhecer quem iniciou ou patrocinou este início foi colocada a pergunta: As atividades KAIZEN foram iniciadas por:

- Em que amplitude o KAZEN foi introduzido na empresa, assim através da pergunta os conceitos do KAIZEN foram divulgados para:.... se procurou obter esta informação. 
- Uma das atividades ligadas ao KAIZEN é o programa de sugestões ou programa de sugestões de melhorias (Imai, 1992). Através da questão se o sistema de sugestões de melhoria tem alcançado a participação do pessoal, procura-se saber qual é o grau de participação das pessoas neste programa ou qual o nível de sucesso deste programa.

- Ainda baseado no conceito de que o KAIZEN é uma metodologia onde se tem várias ferramentas para implementação das atividades de melhoria continuamente na questão (Imai, 1992) "A Ferramenta aplicada mais frequentemente é:" se deseja saber qual destas ferramentas é a mais utilizada.

- Mais uma vez, agora neste bloco relacionado à implementação do KAIZEN, é questionado como o a área de recursos humanos da empresa está envolvida nestas atividades ou no programa como um todo, porque é fundamental esta participação (Forrester, 1995), este é o teor da informação que se deseja através da pergunta: A participação da Área de Recursos Humanos é:

- Com a pergunta sobre qual a forma de condução das atividades KAIZEN, se procura saber se existe uma forma específica de administração para o planejamento e acompanhamento dos trabalhos relacionados com o KAIZEN.

- A participação dos Operadores nas atividades KAIZEN é. A última pergunta do bloco questiona o quanto os operadores estão engajados no programa KAIZEN.

E- Resultados advindos das atividades KAIZEN, neste bloco do questionário as perguntas foram direcionadas para o entendimento dos resultados criados pela prática das atividades do KAIZEN. Esta é a parte fundamental do questionário porque seria de onde se obteria as informações para validação ou não da proposição desta pesquisa .

- Houve mudança cultural na Manufatura devido às atividades KAIZEN? Nesta primeira pergunta deste bloco foi buscada diretamente a informação de um dos principais aspectos da metodologia KAIZEN, a 
mudança cultural. Considerado o evento que realmente gera o efeito transformador dentro da manufatura.

- Muitas vezes com o programa KAIZEN e a busca pela eliminação de perdas aparecem o sentimento de redução das oportunidades, número de vagas disponíveis e conseqüente redução do número de empregos, com a pergunta, houve o sentimento de ameaça no ambiente da Empresa por causa do KAIZEN? Buscam-se informações se houve a percepção deste temor dentro da empresa causado pelas atividades KAIZEN.

- Com a questão: "As melhorias, com relação ao resultado financeiro, contribuíram com o ganho de:", se pretende obter as informações sobre o resultado financeiro advindo das atividades e melhorias já implementadas com o programa KAIZEN. Foi procurado tido o cuidado de se facilitar o respondente ao solicitar informações relativas e não valores absolutos, pois os últimos muitas vezes são confidenciais.

- Como é feita a contabilização das atividades KAIZEN? Esta questão solicita informações de qual é o método utilizado para se contabilizar aquilo que foi despendido e aquilo que se ganha com a aplicação da metodologia KAIZEN. Foi considerados que se sem um formato definido de contabilização muitos dos ganhos e gastos ficam obscuros e difíceis de serem obtidos (Hiromoto, 1988)

- Um dos fatores comentados por Imai(1992) é que o KAIZEN modifica positivamente a motivação do pessoal participante e esta é a informação solicitada na pergunta se a motivação do pessoal foi melhorada com as atividades KAIZEN.

- Uma vez que os ganhos começam a aparecer é difícil mantê-los? Na questão sobre se há dificuldade para manutenção dos ganhos, seria esta a informação desejada.

- Fatores para o sucesso das atividades, nesta questão a informação solicitada é de interesse relevante pois orientaria os iniciantes nas atividades KAIZEN como direcionar os trabalhos aplicando as práticas 
sugeridas pelos fatores de sucesso em outras empresas. Na pesquisa esta questão é fundamental para análise dos resultados obtidos.

- Qual o principal cuidado para sustentar o Programa KAIZEN? Assim como na questão anterior, esta questão nos traz informações importantes para análise dos resultados, pois com ela poderemos fazer cruzamentos de referências com as questões correspondentes aos resultados diretos obtidos pelo programa KAIZEN.

F- Outros aspectos. Neste último bloco foi solicitado ao respondente que comentasse e opinasse sobre a Metodologia KAIZEN e o impacto que ela pode oferecer na Indústria de Autopeças. O objetivo deste bloco foi o de dar uma oportunidade ao respondente de descrever ou dar informações que não foram solicitadas nos demais blocos de perguntas. Também foi a oportunidade de que o respondente desse sua opinião pessoal sobre a metodologia KAIZEN. 


\section{RESULTADOS}

Como o objetivo da pesquisa tem como alvo a população das empresas fabricantes de autopeças que aplicam a metodologia KAIZEN, apenas os resultados referentes às empresas respondentes deste grupo serão avaliados. Inicialmente, a partir do recebimento dos questionários respondidos, foi feita uma tabulação para se verificar a freqüência das respostas em cada pergunta, permitindo, assim, uma avaliação dos resultados, individualmente, questão a questão. A tabela com a distribuição das respostas encontra-se no apêndice. É importante afirmar que, como mencionado por Caminada (2006), "a análise não constitui um fim em si mesma", sendo, aqui, uma contribuição para entendimento das diversas faces do problema, possibilitando uma discussão sobre a proposição desta pesquisa.

Os resultados são apresentados em gráficos de barras contendo a freqüência das respostas para cada questão. Em cada gráfico foi colocado um breve comentário sobre a distribuição dos resultados.

Após esta avaliação inicial, no capítulo 8, foi feita uma análise com cruzamento das respostas de diferentes questões, mas correlatas no sentido de se testar a proposição.

Na questão 1 do bloco $B$ do questionário, se percebe uma concentração maior, figura 15, 6 respondentes, afirmando que o conceito de valor agregado e valor não agregado está de forma razoável estabelecido na empresa, a interpretação para esta resposta é que no mínimo $60 \%$ do pessoal destas empresas tem este conceito. O espectro de respostas aponta também que o restante dos respondentes considera que este conceito esta estabelecido de forma grande, 4 respostas, e muito grande, 1 resposta. $\mathrm{Na}$ totalidade, as respostas nos mostram que nas empresas pesquisadas, todas com programas KAIZEN, o conceito de valor agregado e não agregado é bem firmado e isto é base para o entendimento e participação do pessoal nas diversas atividades, pois não havendo este conhecimento ficaria muito difícil haver um bom aproveitamento do pessoal nestas atividades, a priorização e foco dos trabalhos não seriam eficazes, ou seja, há a possibilidade de atuação e de direcionamento de ações em questões que não estariam necessariamente focadas na eliminação ou redução das atividades que não agregam valor, acontecendo, nestes casos, um grande desperdício de energia e tempo, itens bastante escassos no mundo 
empresarial atual. Por esta razão, estes conceitos devem ser bem colocados a todos na empresa, fazendo com que as contribuições de cada um para as melhorias sejam mais eficazes.

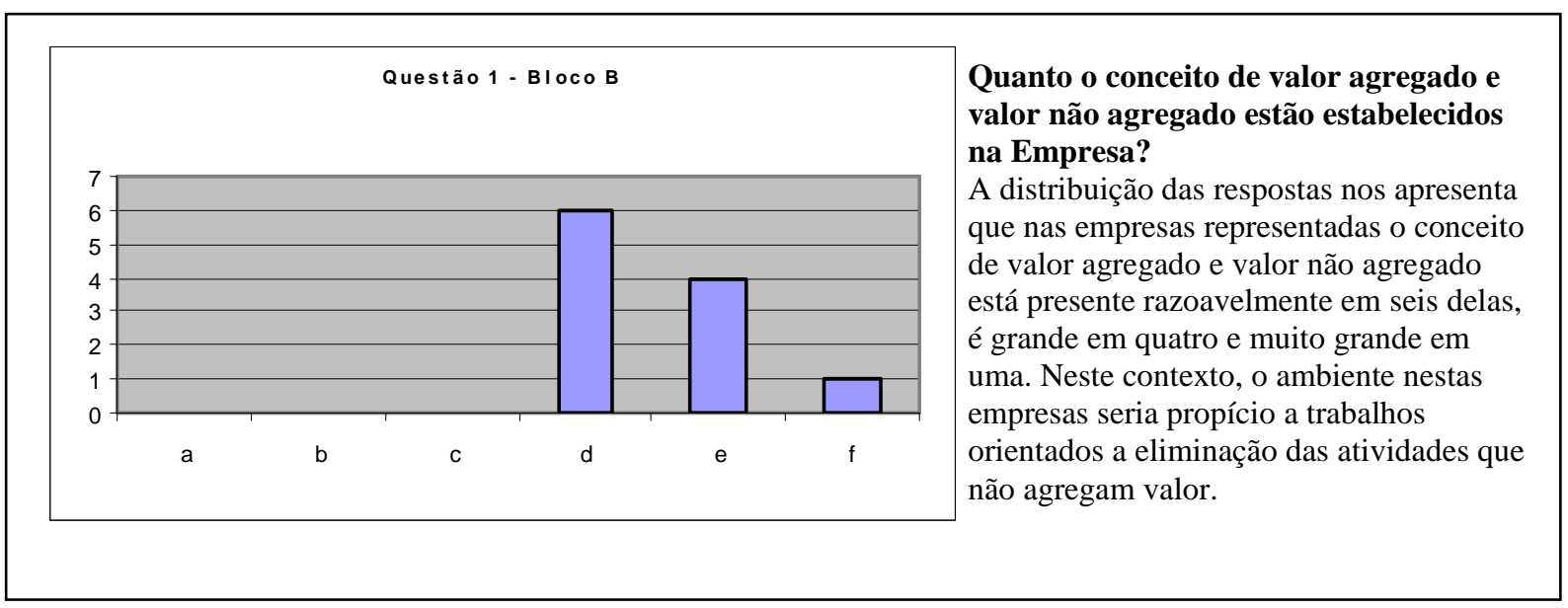

Figura 15 - Distribuição das respostas à questão 1 do Bloco $B$.

As iniciativas estruturadas para melhoria da produtividade, seriam aquelas que, uma vez conhecida a situação real da área onde se quer melhorar, busca-se as causas das perdas de produtividade e, através das causas identificadas, há uma ou mais ações para reduzir ou eliminar esta perda, exemplificado por Kumar e Harms (2004). As respostas à questão 2 do bloco B, Figura 16, mostram que em sete das empresas pesquisadas é grande o número de iniciativas estruturadas para melhoria de produtividade e em três delas é muito grande o número destas iniciativas. Em apenas uma das empresas o número de iniciativas foi considerado razoável. O programa KAIZEN, nestas empresas, deve ter tido um papel fundamental para que haja este resultado em relação às iniciativas de melhoria de produtividade, pois um dos alvos comuns dos trabalhos de KAIZEN é o ganho de produtividade (Brunet e New,2003), dando-se de forma estruturada consegue-se obter os melhores resultados pela otimização dos recursos aplicados (Sommerville, 1996). A metodologia KAIZEN é considerada uma forma de atuação que, com recursos limitados, se obtém resultados de melhoria de desempenho, mas não pode ser considerada uma forma de trabalho em que se atua a esmo, sem direcionamento, esta é a razão da necessidade de estruturar os trabalhos voltados para o KAIZEN. Como todas as empresas pesquisadas têm um programa de KAIZEN, esta questão tem espectro de respostas bem coerente porque seria esperado como parte destes programas tais ações. 


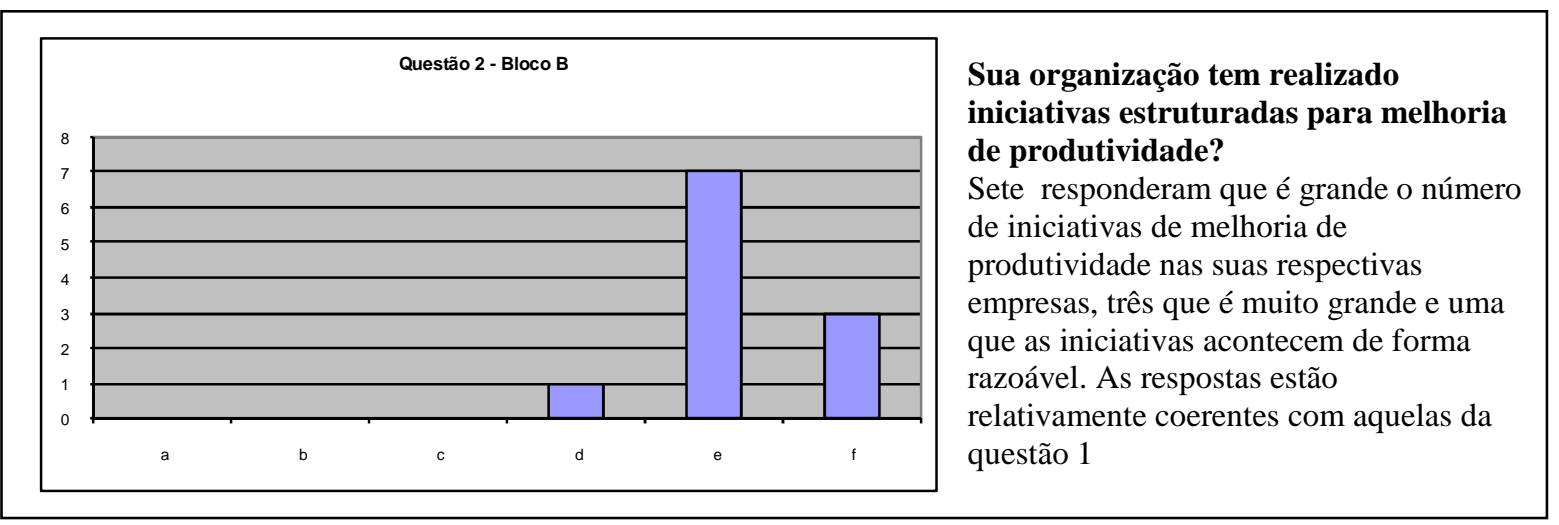

Figura 16 - Distribuição das respostas à questão 2 do Bloco B.

As iniciativas de melhoria geram mudanças e mudanças, muitas vezes, geram oposição e barreiras como mencionado por Patel, Dale e Shaw (2001) na descrição de trabalhos para redução de tempo de troca de ferramentas em quatro empresas no Reino Unido. Na questão número 3 do bloco B (Figura 17), esta questão foi colocada e os resultados apresentados indicam que as barreiras são pequenas em muitas das empresas, 5 respostas, uma delas tem barreiras muito pequenas e em 4 empresas têm resistência razoável. Pode-se considerar que os programas KAIZEN implementados na maioria das empresas estão postos de forma consistente, pois o nível de oposição às iniciativas de melhoria, de acordo com as respostas à questão, somente é grande em um dos casos. Esta distribuição de respostas é, a princípio, coerente em relação às questões anteriores do mesmo bloco, em ambientes onde existem iniciativas estruturadas de melhoria e conhecimento do conceito de valor agregado e não agregado, as barreiras a estas iniciativas não é grande.

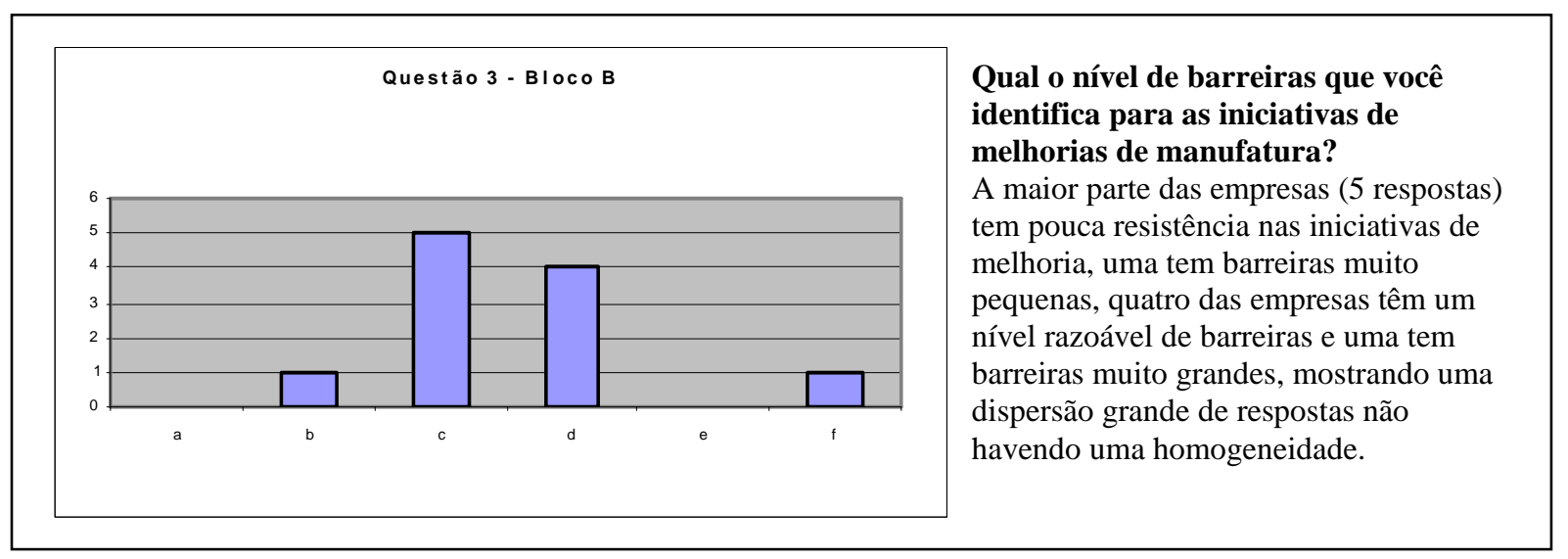

Figura 17 - Distribuição das respostas à questão 3 do Bloco B. 
O fluxo de valor é o conjunto de todas as atividades que ocorrem desde a obtenção de matéria prima até a entrega ao consumidor do produto final (Rother e Shook, 1996). Através do mapeamento do fluxo de valor em uma empresa se consegue ver os pontos onde existem as maiores oportunidades de melhoria. Quanto mais áreas de uma empresa forem mapeadas, maior a possibilidade de se ter eficácia para encaminhamento dos programas de melhoria e colocar a empresa em uma situação de melhor rentabilidade. Quando foi feita a pergunta quatro do bloco B (Figura 18) do questionário a respeito do quanto este mapeamento fora realizado, se estava pedindo a informação de quanto se conhece dos problemas e oportunidades nas empresas dos respondentes. Pelo resultado das respostas recebidas vê-se que duas das empresas foram totalmente mapeadas e mais duas tiveram grande parte de suas áreas mapeadas. Nestas empresas seus respectivos programas de melhoria contínua devem estar bastante avançados porque o material para subsidiar o trabalho deve ser bem farto. Enquanto isso três empresas foram mapeadas em metade de suas áreas e outra empresa teve pouco mapeamento, sendo que apenas uma das empresas teve muito poucas áreas mapeadas. 0 resultado geral desta questão evidencia que as empresas respondentes a esta pesquisa estão, conforme análise à resposta anterior deste bloco, avançadas em seus programas KAIZEN.

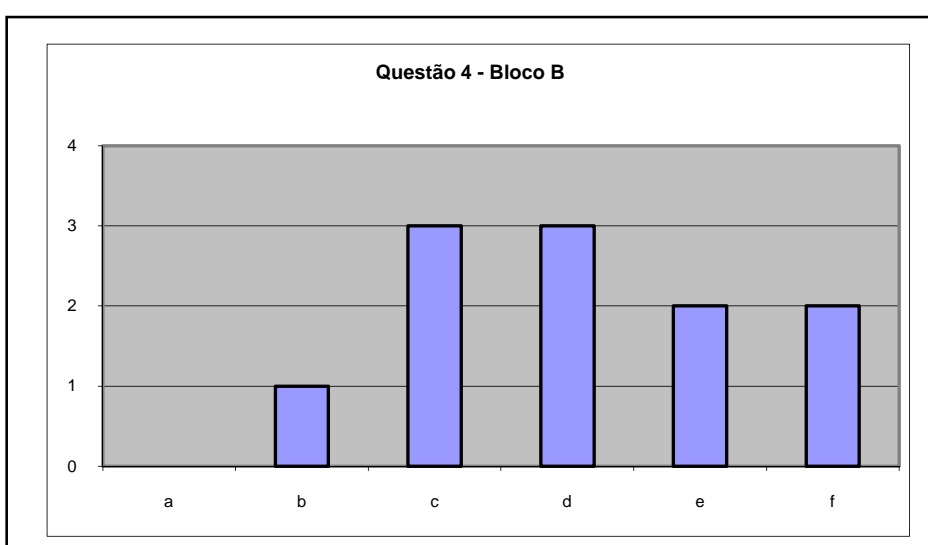

Quantas áreas de manufatura foram
mapeadas em relação ao fluxo de
valor(Value Stream Map?
Todas as empresas pesquisadas tiveram
mapeamento de fluxo de valor. Apenas duas
foram mapeadas totalmente, mais duas
foram mapeadas em grande parte, três
tiveram metade de suas áreas mapeadas e
três tiveram pouco mapeamento. Apenas
uma teve muito poucas áreas mapeadas. Este
mapeamento é importante porque
identificam as perdas e consequentemente as
oportunidades de melhoria

Figura 18 - Distribuição das respostas à questão 4 do Bloco B.

O quanto é aberto o ambiente dentro da manufatura é a questão cinco do bloco $B$ (Figura 19). O significado dela nos leva a ter que considerar uma comparação desta com a questão sobre a existência de barreiras às iniciativas de melhoria, questão três do bloco B, porque as perguntas são praticamente complementares, pois em um ambiente na manufatura aberto para mudanças não haveria barreiras para as 
iniciativas de melhoria. As empresas com mais alto desempenho são aquelas com cultura para uma sustentável e pró-ativa melhoria (Achanga; Shehab; Roy e Nelder, 2005). As respostas para a questão cinco do bloco $B$ apresentaram uma distribuição indicando que as empresas têm o ambiente da manufatura aberto às mudanças, apenas uma das empresas respondeu que tem o ambiente pouco aberto. As demais empresas respondentes têm: ambientes razoavelmente aberto, com quatro respostas, ambientes com grande abertura, com quatro respostas e duas respostas afirmando que têm ambientes com abertura às mudanças muito grande. A comparação com a questão sobre as barreiras às mudanças indica que os resultados das duas questões são muito semelhantes. O trabalho já realizado na direção do KAIZEN demonstra que já teria produzido efeitos, inclusive, na maneira como o ambiente da manufatura é propício para as mudanças. Mas o resultado desta questão também nos leva a outra dúvida, será que ambiente é aberto às mudanças por causa do KAIZEN ou o programa foi iniciado e levado a diante exatamente porque o ambiente na manufatura já era aberto aos conceitos colocados por um programa como é o KAIZEN? Infelizmente não foi possível obter esta resposta, mas não pode-se deixar de ter uma consideração a respeito disto quando das conclusões sobre o tema.

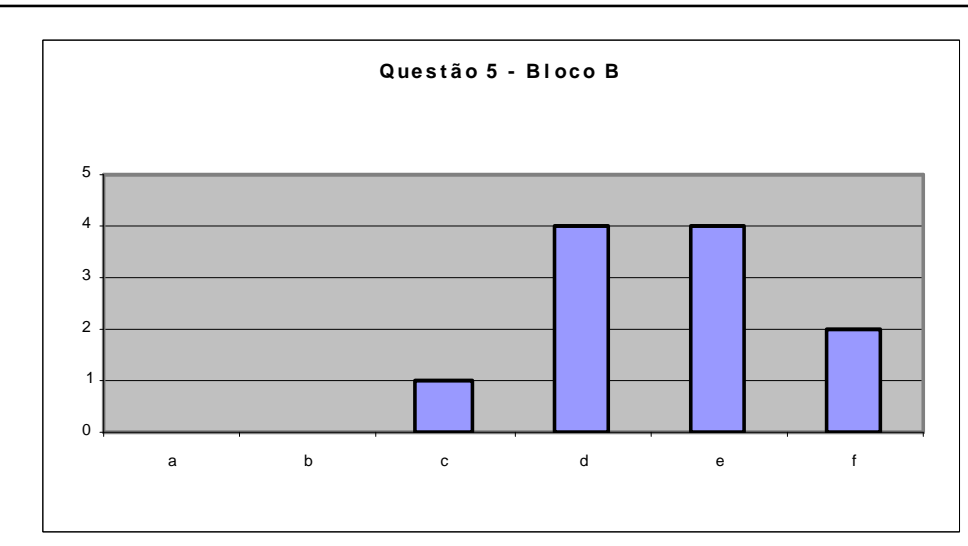
O ambiente da manufatura é aberto para mudanças?
Pelo resultado apresentado as empresas têm ambientes abertos às mudanças, o que favorece a implementação do KAIZEN. Apenas uma empresa tem o ambiente fabril pouco aberto às mudanças, quatro têm ambientes razoavelmente abertos, outras quatro têm grande abertura às mudanças e duas têm a área de manufatura com uma abertura muito grande às mudanças.

Figura 19 - Distribuição das respostas à questão 5 do Bloco $B$.

Quando se discute sobre KAIZEN em uma empresa não se pode esquecer que esta empresa não existe solitária e única dentro de uma cadeia de fornecimento, ela coexiste com seus fornecedores e clientes, havendo a necessidade de se estender os benefícios a todos (Bhasin e Burcher, 2004). Assim, é importante que haja um alinhamento entre o que acontece nesta empresa, em termos de políticas, e os outros elos desta cadeia. Com isto há um crescimento de toda a cadeia, como no 
exemplo daquilo que ocorreu quando a Fábrica da Toyota passou a difundir seu sistema de produção, no início dos anos 1970, com seus fornecedores. Neste sentido, foi perguntado através da questão seis do bloco B (Figura 20) sobre a existência deste alinhamento. O resultado apresentou um quadro disperso entre as empresas pesquisadas, em cinco delas o alinhamento é pequeno, em cinco o alinhamento é grande e uma das empresas respondeu que tem o alinhamento razoável. Pode-se considerar a possibilidade que, entre as empresas com pouco ou razoável alinhamento, ainda não houve ações para promover este alinhamento. Talvez as empresas com pouco ou razoável alinhamento ainda estejam amadurecendo seus próprios programas internos para depois haver o pensamento direcionado à cadeia de fornecimento. Se for este o caso, este seria um encaminhamento correto, pois para compartilhar um programa desta magnitude deve haver certa experiência própria para a empreitada. Outra possibilidade para a ocorrência de empresas com pouco alinhamento com a cadeia de fornecimento seria que os fornecedores ainda não estivessem prontos para assimilarem ou iniciarem um trabalho voltado para a metodologia KAIZEN. Estas empresas, então, deverão fazer, por exemplo, um programa de treinamento para seus fornecedores, afim de que estes venham a conhecer e se interessarem pelos possíveis benefícios que 0 KAIZEN daria à parceria.

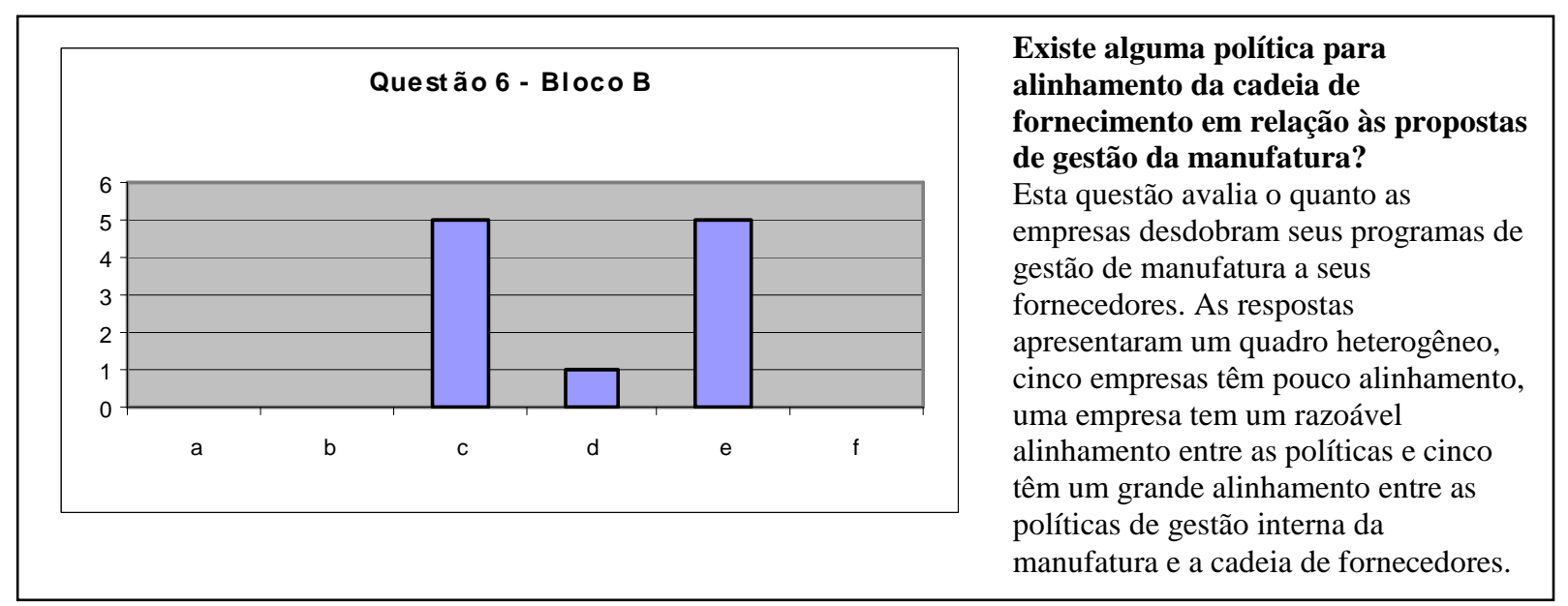

Figura 20 - Distribuição das respostas à questão 6 do Bloco B.

Quando há a introdução de novas tecnologias na manufatura podem haver distorções que afetam diretamente o desempenho deste setor (Coffey e Thornley, 2006). Estas distorções seriam causadas por uma falta de sintonia entre o sistema de gestão praticado pela manufatura, a partir da manufatura enxuta e apoiada pela 
metodologia KAIZEN, e os desenvolvedores destas novas tecnologias dentro da própria empresa. Esta falta de sintonia pode aumentar as perdas na manufatura. A Questão sete do bloco B (Figura 21) questionou às empresas participantes da pesquisa o quanto este desenvolvimento destas novas tecnologias, em forma de produtos e processos, leva em consideração as perdas da manufatura. As respostas apresentadas indicam que sim, as empresas levam em consideração as perdas da manufatura quando do desenvolvimento de novas tecnologias. Apenas uma das empresas respondeu que não há esta consideração na introdução de suas novas tecnologias. Nas demais empresas a consideração é razoável, uma resposta, grande consideração, cinco respostas e muito grande consideração, quatro respostas. A razão para haver esta empresa com um comportamento tão distinto em relação às demais, pode ser que esta empresa não tenha sofrido, em nenhum momento de sua história, problemas com estas introduções de novas tecnologias não dando prioridade a este tipo de consideração. O momento do início do projeto de novos processos ou produtos na manufatura é um momento de grande importância, pois é neste momento que se deve levar em conta as práticas já consolidadas na manufatura, fruto de atividades do KAIZEN, lições aprendidas com as dificuldades que já foram enfrentadas e outras experiências.

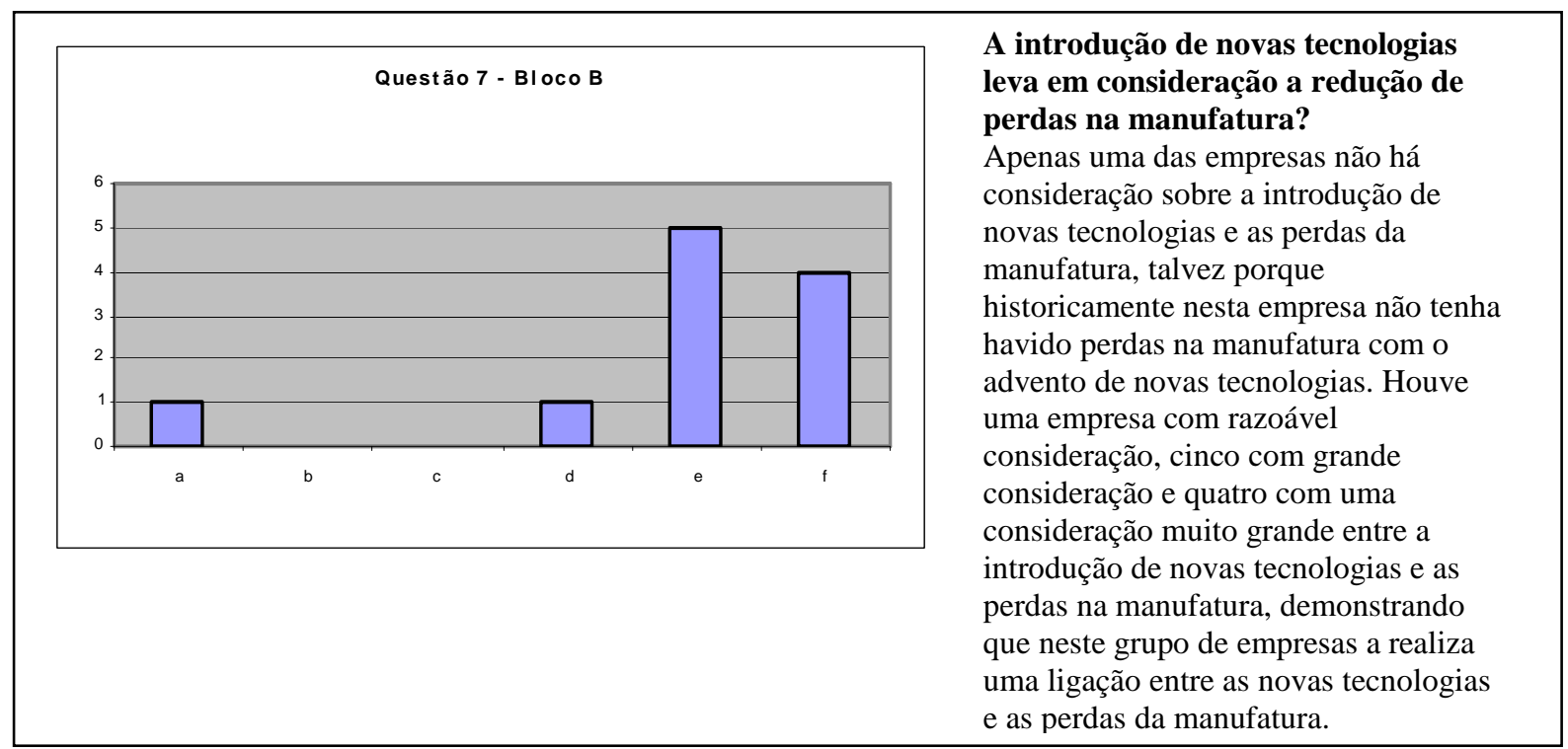

Figura 21 - Distribuição das respostas à questão 7 do Bloco B.

Conforme Ohno (1988), uma das perdas na manufatura é o excesso de estoque, por isto é importante que haja algum trabalho no sentido de eliminar ou reduzir esta perda. A questão oito do bloco B (Figura 22) solicita aos respondentes a informação de quanto é colocada esta questão no programa KAIZEN, ou seja, qual seria a 
prioridade deste assunto dentro do programa dentre as outras perdas considerada por Ohno(1988). As respostas recebidas apresentaram um espectro que nos permite afirmar que todas têm consideração na redução desta perda. Uma das empresas responde que a consideração é razoável, cinco afirmam ter grande consideração e as outras cinco a consideração é muito grande. O resultado recebido mostra que a redução de estoques é uma das prioridades dentre as perdas da manufatura e que existem ações, dentro do KAIZEN, voltadas para esta redução.

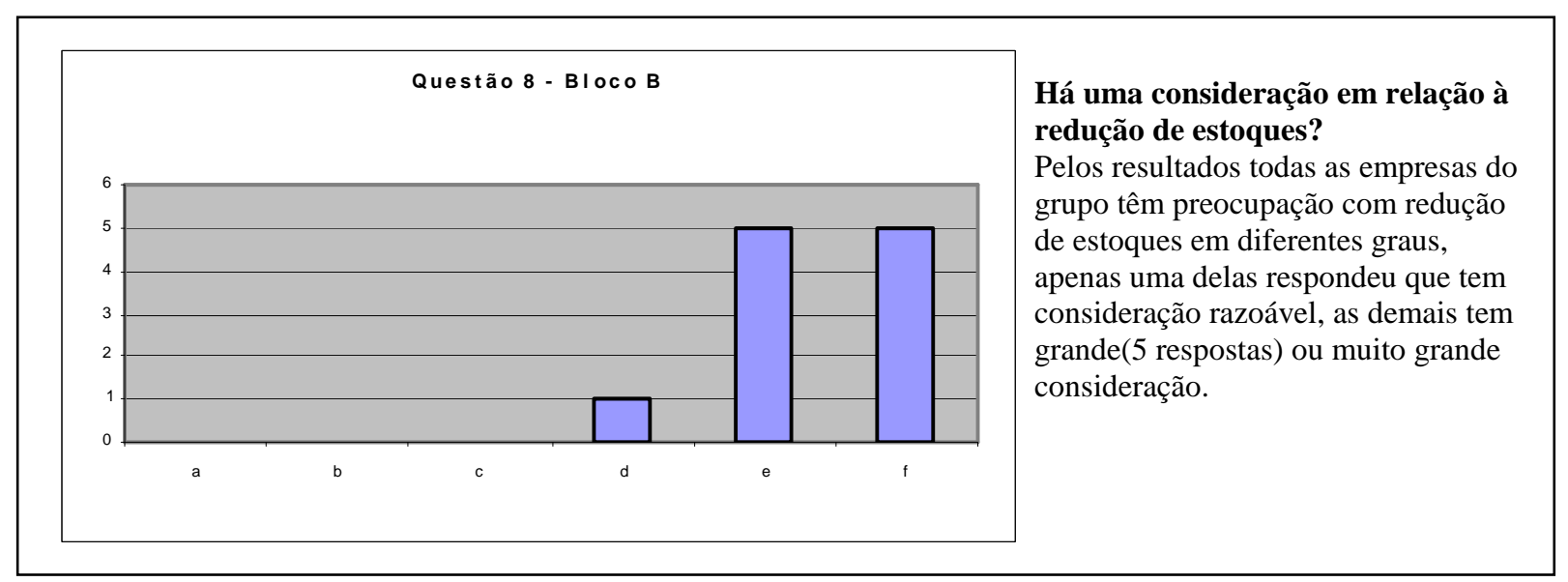

Figura 22 - Distribuição das respostas à questão 8 do Bloco B.

Uma das, muitas vezes mencionada, fraquezas da manufatura enxuta é que o fator humano é relegado (Forrester, 1995; Siekman, 2000 apud Bhasin, Burcher, 2006). No programa KAIZEN este fator humano é preponderante, pois esta presença é importante em todas as ferramentas do programa ( Imai, 1992), sem as pessoas não há KAIZEN. Na pergunta nove do bloco B (Figura 23) foi questionado se existe uma política de desenvolvimento de pessoal nas empresas pesquisadas exatamente para se saber como este fator humano está sendo levado em conta nestas empresas. Cinco empresas responderam que esta política de desenvolvimento é grande, indicando que neste grupo de empresas há uma grande preocupação com o aumento de capacitação de pessoal para obter melhores resultados com seus programas KAIZEN. Quatro empresas têm política razoável, não há uma priorização forte, mas, o fator humano não foi colocado de lado. Nos dois extremos do espectro de respostas temos uma empresa onde a política de desenvolvimento de pessoal é muito pequena, esta empresa não deve ter uma política estruturada de desenvolvimento de pessoal, apenas ações pontuais sem haver um padrão de atuação. Por outro lado obtêm-se uma empresa com uma política de 
desenvolvimento muito grande, muito provavelmente esta política exista para fortalecer o programa KAIZEN.

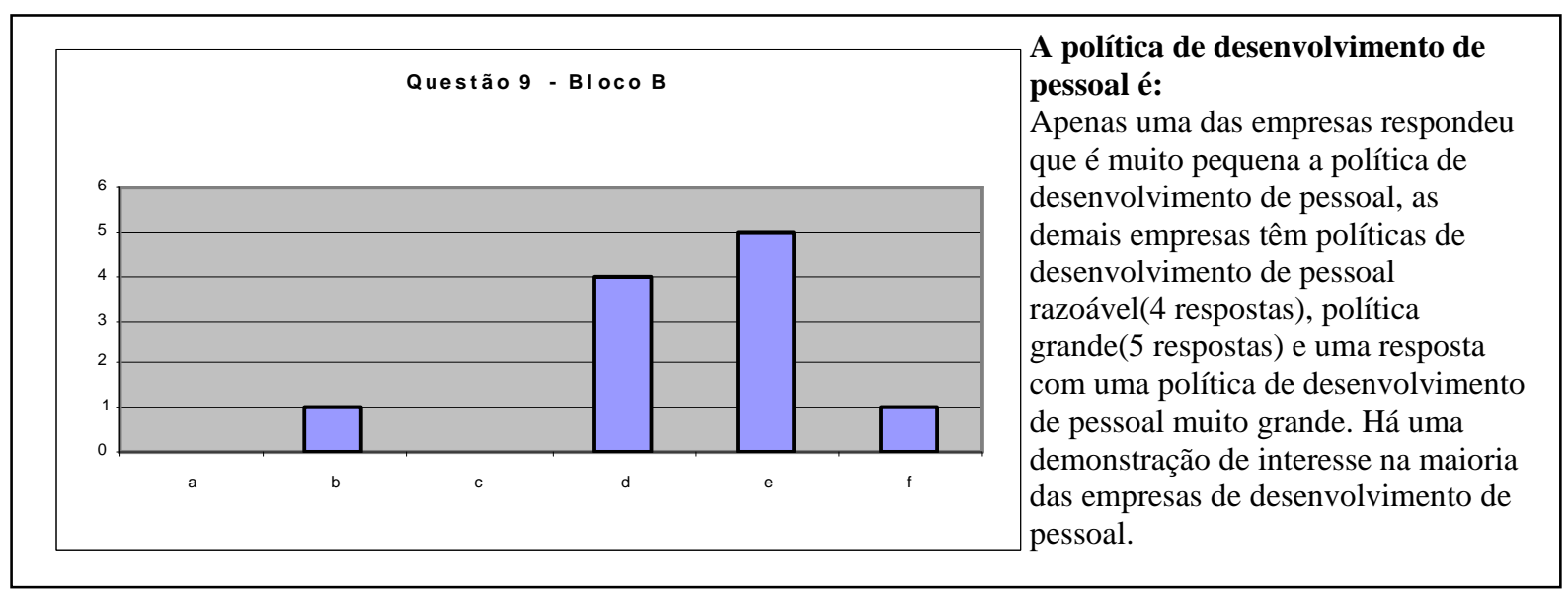

Figura 23 - Distribuição das respostas à questão 9 do Bloco B.

A condução de melhorias no chão de fábrica deve ter a participação ativa dos supervisores ou líderes (Imai, 1992). Estes supervisores e líderes do chão de fábrica teriam que estar bem preparados e conscientes de seu papel na condução destas melhorias, sendo fatores críticos para o sucesso da implementação (Achanga, Shehab, Roy e Neldar, 2005). Teriam, além do papel de condução dos trabalhos, o papel de orientação, treinamento e acompanhamento após implementações (Tabela 1). A primeira questão do bloco C (Figura 24) pergunta em outras palavras, se estes líderes e supervisores tomam a frente dos trabalhos de melhoria na empresa ? As respostas a esta pergunta ficaram na maior parte com a opção "condução grande", 6 respostas, alem de três respostas dizendo que a liderança tem uma participação na condução das atividades de melhoria razoável e apenas duas respostas informando que a participação é pequena. As respostas com a informação de que a participação da liderança é pequena podem vir de empresas que estariam com seus programas KAIZEN em fase de implementação. Nesta fase a liderança está sendo treinada e ainda tem poucos líderes tomando a frente das atividades. Se não for este o caso, que processo de implementação nas empresas com pequena participação é iniciante, estas empresas podem estar com dificuldades em seus programas KAIZEN, pois sem a participação da liderança a frente dos trabalhos de melhoria há dificuldades muito grandes para o andamento do programa. 


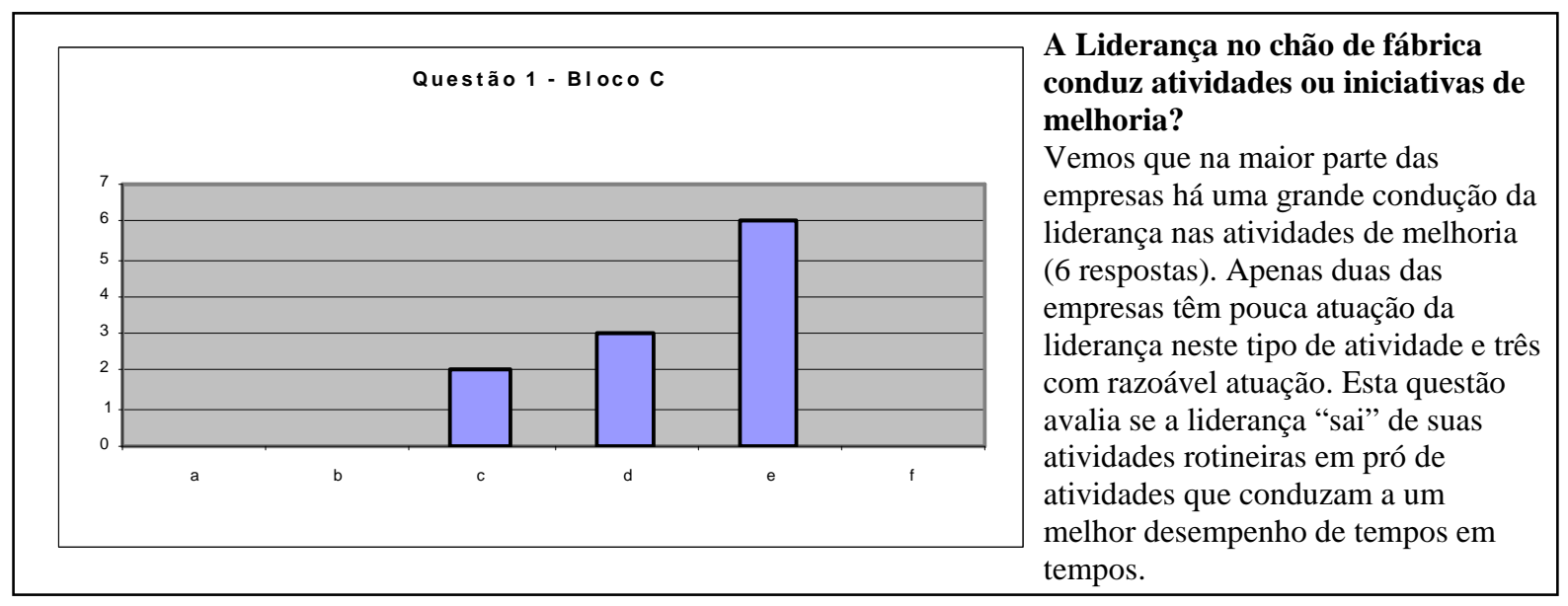

Figura 24 - Distribuição das respostas à questão 1 do Bloco C.

Para se ter acesso à metodologia para o programa KAIZEN é preciso ter o conhecimento de seus conceitos, práticas, formas de implementação e experiência. Quando uma empresa enxerga a necessidade de iniciar a empreitada na direção do KAIZEN, ela precisa destas competências. Para isto, uma opção, mas não a única, para se adquirí-las seria a contratação de uma consultoria especializada (Achanga, Shehab, Roy e Nelder, 2005). Para saber se as empresas tiveram acesso à metodologia através de uma consultoria foi colocada a questão 2 do bloco $C$ (Figura 25). O espectro de respostas foi bastante diverso, três respostas dizendo que houve uma participação muito pequena, uma resposta para pouca participação de uma consultoria, participação razoável em três respostas e com duas respostas para cada uma das opções de participação grande e muito grande de consultoria. Houve, então, uma distribuição de respostas bem dividida. As empresas não têm escolhido um único caminho para seus programas de KAIZEN, além de apoio de consultoria devem estar criando seus próprios multiplicadores, buscando treinamento e outras formas para adquirirem as competências necessárias para o sucesso do KAIZEN em suas empresas. 


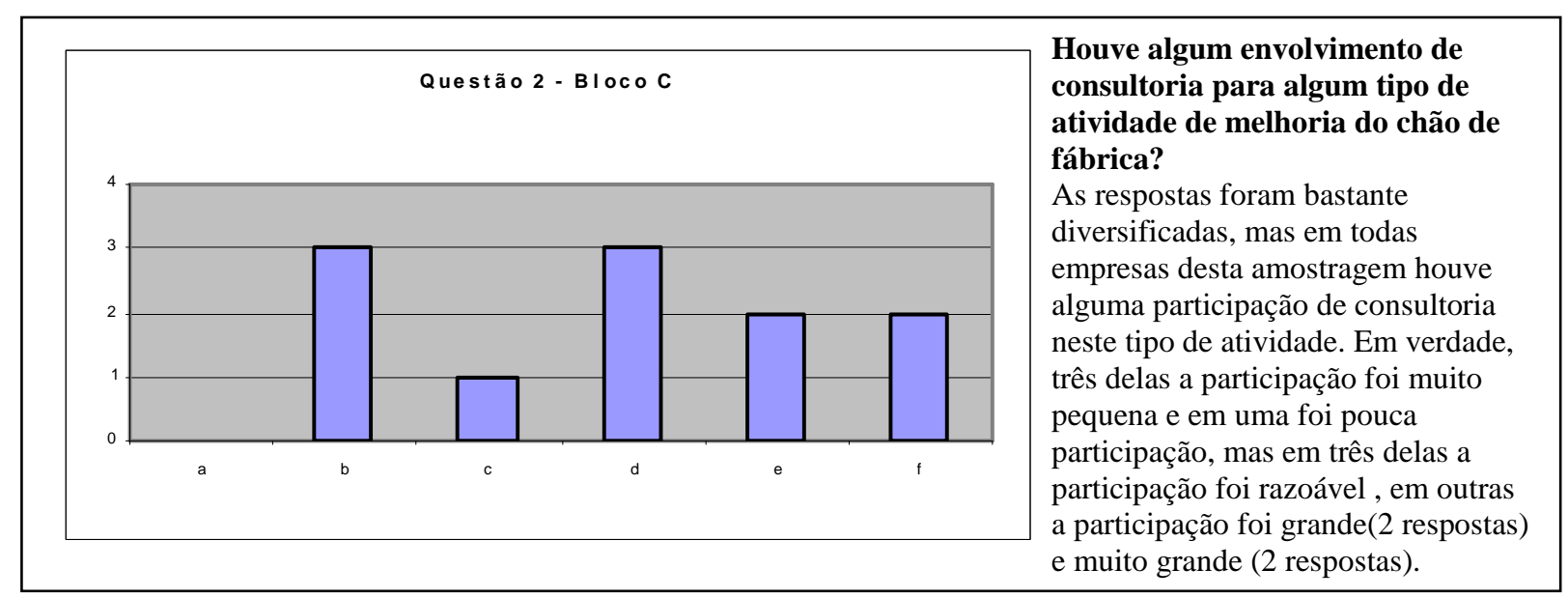

Figura 25 - Distribuição das respostas à questão 2 do Bloco $C$.

No programa KAIZEN é necessária a participação de todos. A participação dos operadores é, da mesma forma, essencial, através da participação nos programas de sugestão e atividades de pequenos grupos, prática de disciplina na área de trabalho, envolvendo-se no desenvolvimento próprio para tornar-se melhor na resolução de problemas, aprendendo várias funções para ressaltar a habilidade e desempenho do serviço (Imai, 1992). Desta forma, é importante se conhecer como é a participação dos operadores nos trabalhos de melhoria contínua nas empresas participantes desta pesquisa. A questão 3 do bloco C (Figura 26) formaliza esta pergunta e as respostas apresentadas indicam que na maioria das empresas respondentes, cinco respostas, há uma participação grande dos operadores, e duas empresas responderam que a participação dos operadores é muito grande. Da mesma forma que na questão sobre a participação da liderança na condução das atividades de melhoria (Questão 1 do bloco $\mathrm{C}$ ), as empresas que têm mais participação dos operadores devem ter seus programas mais avançados e já podem estar colhendo os resultados das melhorias. As demais respostas obtidas mostram um quadro que pode representar que estas empresas ainda estejam nos estágios iniciais de seus programas KAIZEN, pois tivemos uma resposta cuja empresa tem a participação muito pequena, outra com a participação pequena dos operadores e uma com uma participação razoável de seus operadores. Nestes estágios iniciais os conceitos do KAIZEN ainda não estão firmados na manufatura e, talvez, seja esta a razão das respostas das empresas que têm participação de razoável a muito pequena dos seus operadores. 


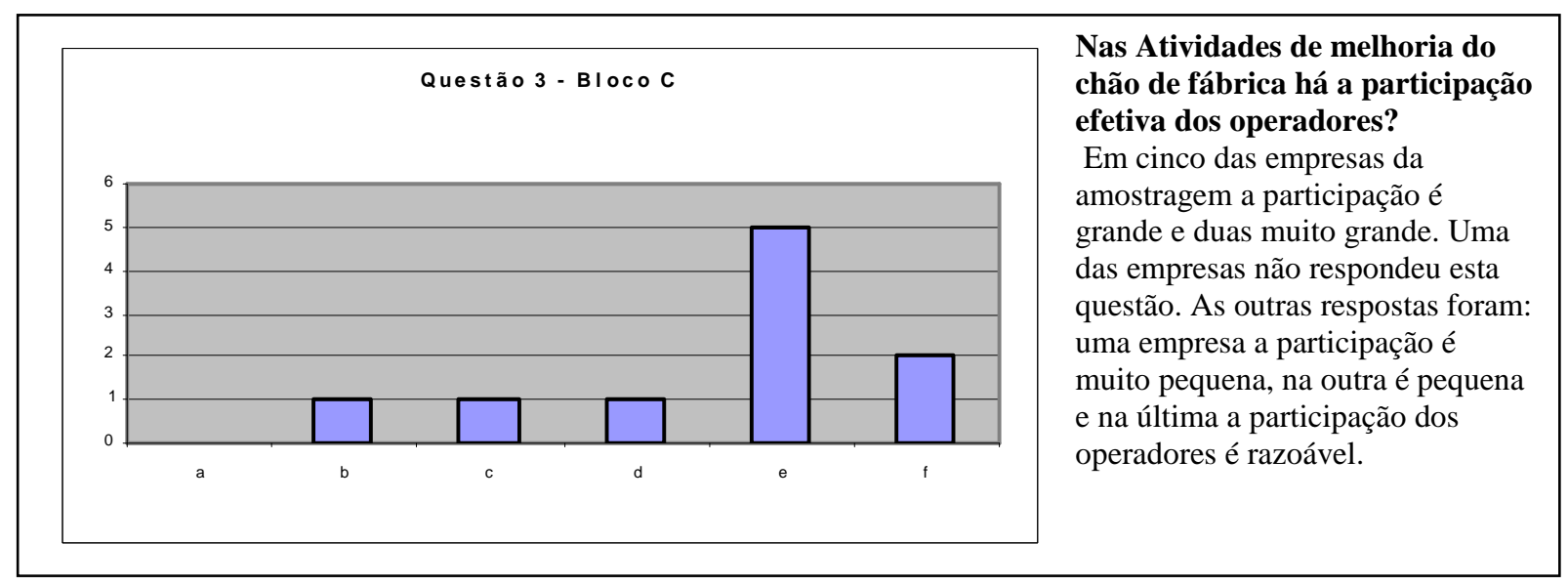

Figura 26 - Distribuição das respostas à questão 3 do Bloco C.

Quando os conceitos do KAIZEN não estão bem estabelecidos, e a cultura interna não estar direcionada para um ambiente de melhoria contínua, pode acontecer de um trabalho inicial do KAIZEN não ter continuidade, analogamente seria como iniciar uma obra de construção de uma casa, mas não dar continuidade a esta construção por falta de mão de obra para prossegui-la. Na questão quatro do bloco C (Figura 27) foi perguntado se há a continuidade nestas atividades de melhoria iniciadas e pode-se observar que há empresas, duas respostas, em que os respondentes afirmam que as atividades de melhoria têm muito pouca ou pouca continuidade. Este tipo de ocorrência pode causar certa frustração nos condutores do processo, nestes casos há a necessidade de buscar as causas desta falta de continuidade e retomar os trabalhos em novos rumos, se for o caso. Por outro lado temos empresas cujos respondentes informam que a continuidade acontece de forma razoável, quatro respostas, de forma grande, três respostas e uma com continuidade muito grande. Nestas empresas os conceitos e cultura voltados para 0 KAIZEN devem estar em um nível de maturidade que permitem a continuidade das iniciativas de melhoria consistentemente. Estas empresas com nível de continuidade das atividades de melhoria de razoável a muito grande poderiam ser referências para as empresas que se iniciam em seus programas KAIZEN e para as empresas que têm alguma dificuldade em dar continuidade às atividades de melhoria. 


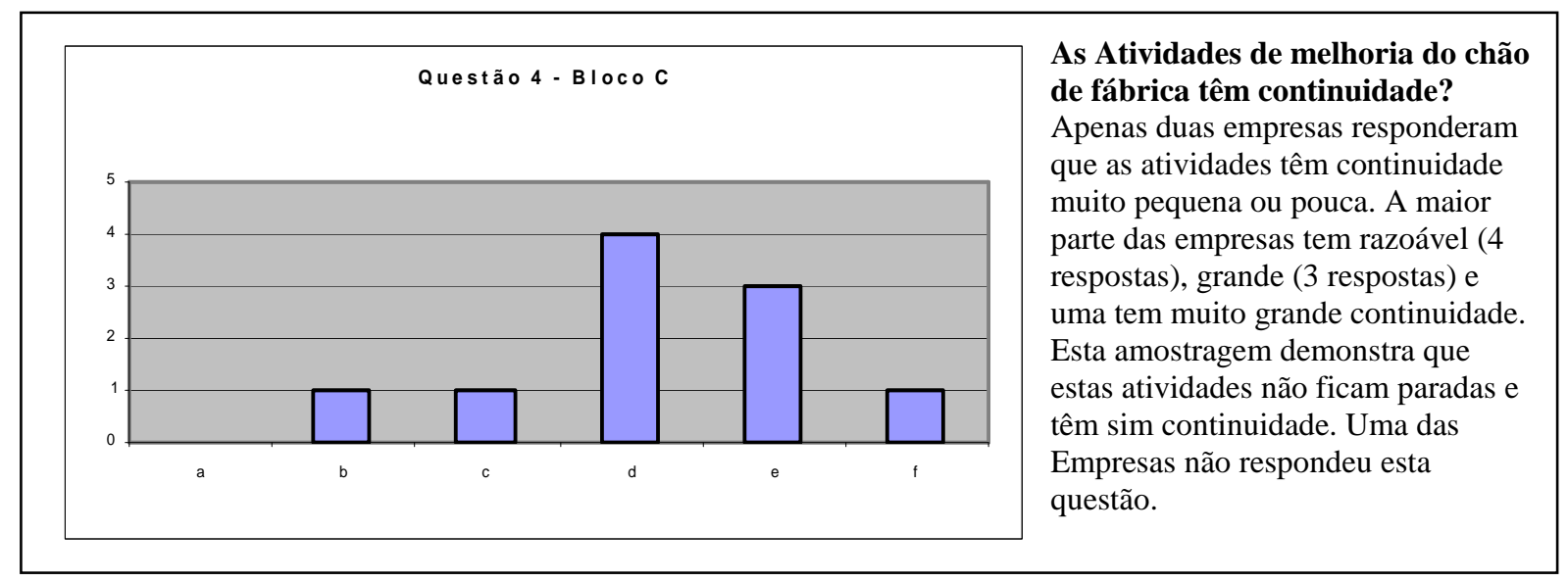

Figura 27 - Distribuição das respostas à questão 4 do Bloco C.

O conhecimento do que realmente é uma perda é um item básico para se direcionar os esforços para eliminação destas perdas. Conforme Ohno (1988), as perdas na manufatura são sete, também chamados os sete desperdícios identificados no Sistema Toyota de Produção, eles são o excesso de produção, as esperas, os retrabalhos, o excesso de inventário; movimentos desnecessários do operário e as peças defeituosas. É necessário que o operador participe das atividades KAIZEN, como mencionado por Imai ( 1992), mas para uma participação efetiva do operador, este precisa saber o que é uma perda na manufatura. A questão 5 do bloco C ( Figura 28) solicita a informação sobre quanto o operador conhece destes conceitos de perda e as respostas recebidas mostram que há empresas cujos operadores não estão preparados para assumirem seus papeis no programa KAIZEN (Tabela 1), em uma das respostas os operadores têm muito pouco conhecimento, em outras duas este conhecimento é pouco, estas empresas devem estar nos estágios iniciais do programa ou necessitam que uma revisão do conhecimento que seus operadores retiveram em seus treinamentos, também pode acontecer que mesmo após treinados sobre os conceitos de perdas, estes conhecimentos não estejam sendo praticados e, por esta razão, não foram retidos. Mas temos empresas em que os operadores estão com o conhecimento razoável sobre os conceitos de perda, três respostas, mais três cujos operadores têm um grande conhecimento e uma empresa onde os operadores têm o conhecimento muito grande sobre os conceitos. No caso destas empresas, pode haver a condição de uma participação ativa dos operadores nas atividades do KAIZEN pois têm o embasamento necessário para esta participação. 


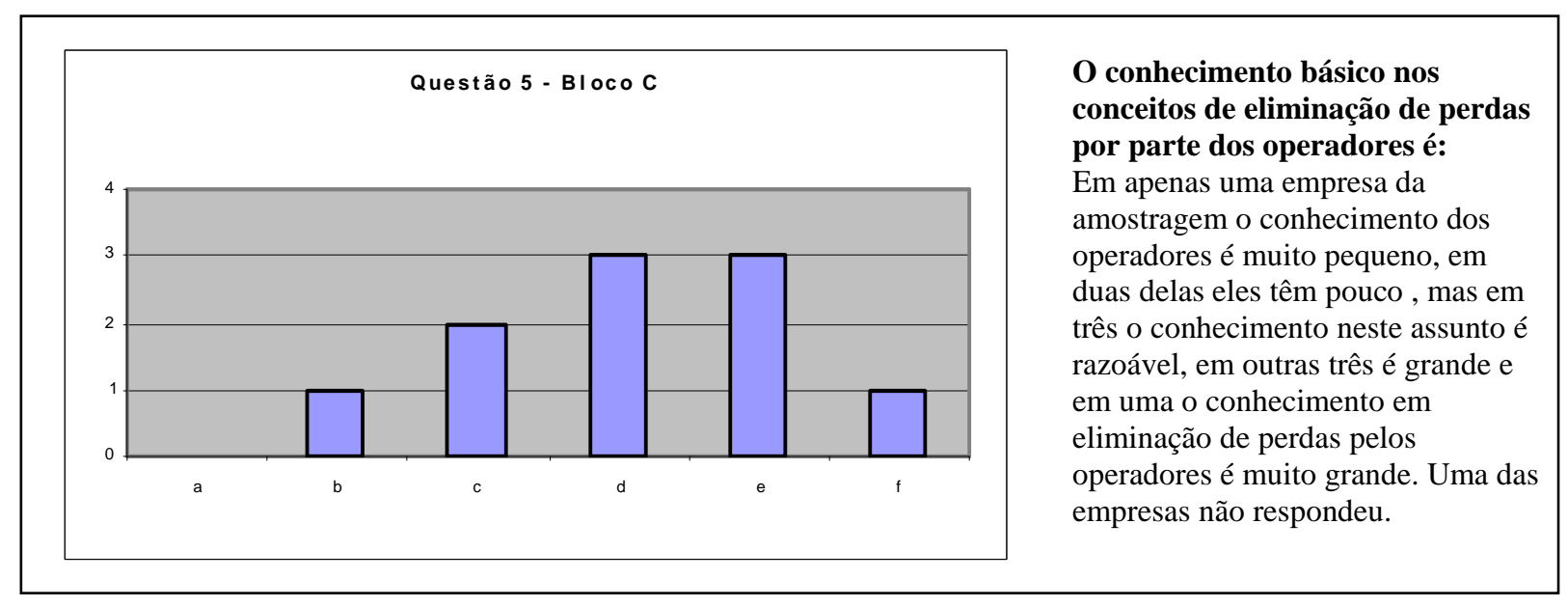

Figura 28 - Distribuição das respostas à questão 5 do Bloco C.

Os grupos de trabalho multifuncionais são muito importantes para desenvolvimento de melhorias, análises e solução de problemas. Dentro da metodologia KAIZEN a atividade em grupo faz parte de várias ferramentas de trabalho (Imai, 1992). Estes grupos de trabalho, dependendo da maturidade da organização, atuam nas tomadas de decisão que influenciam seus ambientes e, através do desdobramento de indicadores, tomarem ações em busca de metas estratégicas. As respostas recebidas à questão seis do bloco C ( Figura 29) mostram uma concentração para a opção de uma existência razoável destes grupos com capacidade para desdobramentos e tomadas de decisão, sete respostas. Houve uma resposta para opção existência muito pequena, outra resposta para pouca existência e duas respostas para a existência grande dos grupos multifuncionais capacitados. O resultado de um grande número de respostas dizendo que existe um número razoável de grupos com capacidade de tomar decisões pode representar que existe uma cultura interna amadurecida nas empresas respondentes que têm este tipo de quadro. Esta situação favorece muito um melhor desempenho do programa KAIZEN e o resultado destas organizações. 


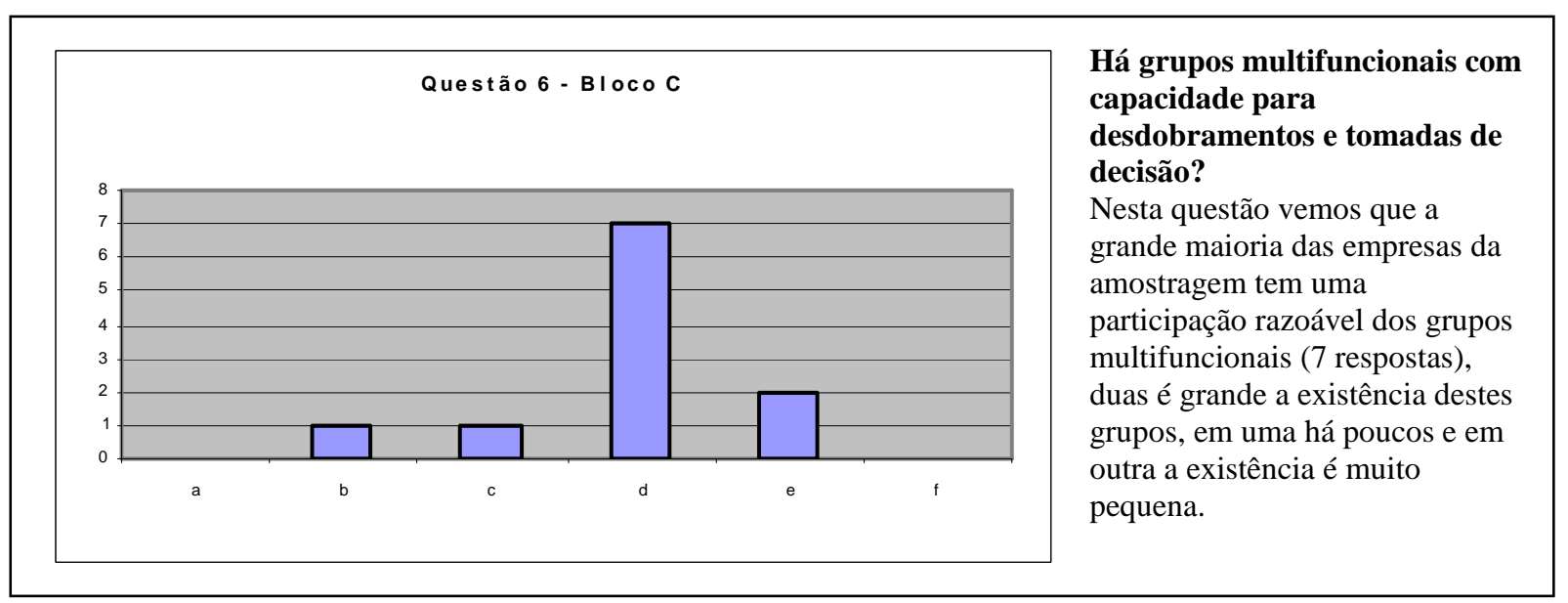

Figura 29 - Distribuição das respostas à questão 6 do Bloco C.

As variações de demanda, principalmente no mercado de autopeças, acontecem com freqüência e é necessário que a empresa tenha flexibilidade para atender as demandas dos clientes, mesmo no ambiente onde há os conceitos da manufatura enxuta há problemas de atendimento a estas variações de demanda (Miyai, 1995). Mas a dúvida seria se a liderança do chão de fábrica estaria capacitada para lidar com as variações. Estas variações, que puxam toda a cadeia de fornecimento, exigem que a liderança, além de terem seus ambientes preparados para esta flexibilidade com eliminação de perdas na manufatura, saiba atuar diante dos desafios e de mudanças de paradigmas existentes, muitas vezes, de longo tempo (Forrester, 1995). O resultado da pergunta 7 do bloco C (Figura 30) é indicativo que a maioria das empresas pesquisadas tem suas lideranças capacitadas para lidar com as variações de demanda, duas empresas informaram que seus líderes tem esta capacidade muito grande, três que seus líderes têm grande capacidade e quatro respondentes informaram que suas empresas têm líderes com capacidade razoável para este tipo de situação. Estas empresas devem ter vantagens competitivas em razão do perfil apresentado por seus líderes no atendimento da necessidade de uma produção flexível, atendendo as variações de demanda de seus clientes. Completando o quadro de respostas, houve dois respondentes que informaram que suas empresas têm líderes com pouca flexibilidade e podem enfrentar problemas com seus clientes por esta razão. Em geral, este resultado, recebido à esta questão, pode ser relativo ao estágio de evolução dos seus respectivos programas KAIZEN, os líderes de ambientes evoluídos e com a cultura voltada para a eliminação das perdas da manufatura podem estar mais 
amadurecidos, mais treinados e, assim, mais capazes de lidar com a flexibilidade necessária às variações de demanda dos clientes.

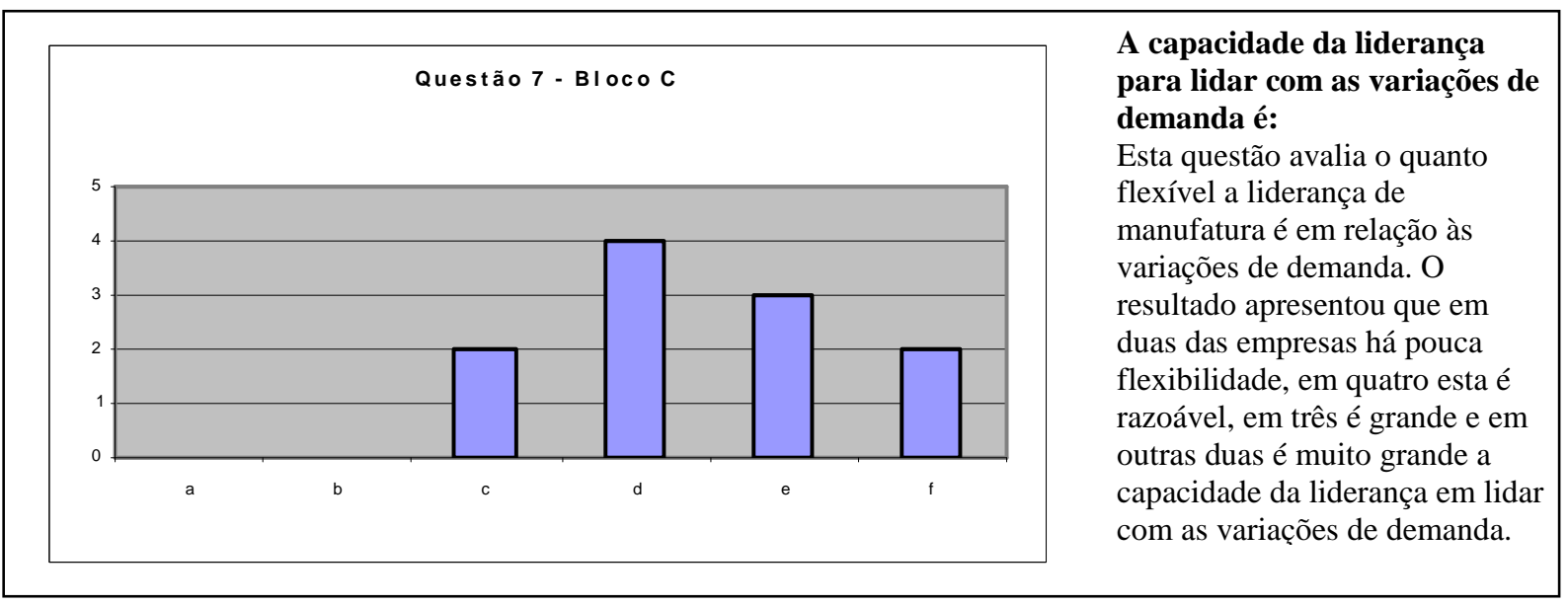

Figura 30 - Distribuição das respostas à questão 7 do Bloco C.

A Mudança é parte integrante da metodologia KAIZEN, com o objetivo de eliminação das perdas ou desperdícios em busca da manufatura enxuta devem acontecer mudanças na área de recursos humanos, no estilo organizacional e na estrutura da empresa. Dentro da manufatura, as empresas devem estar preparadas para mudanças culturais, terem maior flexibilidade, pessoal com habilidades múltiplas, utilização de grupos multifuncionais de trabalho(Imai, 1992). A gestão da manufatura deve contemplar os ambientes decorrentes deste processo de mudança e na questão oito do bloco B (Figura 31) tivemos respostas bem diversas sobre este tema, desde um respondente afirmando que em sua empresa este aspecto é percebido de forma muito pequena, três respondentes informando que em suas empresas isto acontece de forma pequena, em duas empresas há um razoável cuidado até empresas cujos respondentes afirmam que em suas empresas a gestão de manufatura contempla de forma grande, três respostas, e muito grande, uma resposta, os ambientes decorrentes das mudanças. Como já mencionado, a mudança é inexorável no ambiente KAIZEN, assim, as empresas cuja gestão da manufatura cuida mais dos aspectos advindos desta mudança estão aptas a ter mais sucesso em seus programas de melhoria contínua e obterem mais resultados do sistema de manufatura enxuta. Nas demais empresas, onde os cuidados com o ambiente decorrente do processo de mudanças existem de forma muito pequena a razoável, podem existir problemas e, talvez, até retrocessos, pois o resultado das ações do KAIZEN, que se espera, sejam positivos, podem ter algumas 
conseqüências inesperadamente negativas face a reação de resistência às mudanças que podem acontecer e, portanto, devem ser prevenidas.

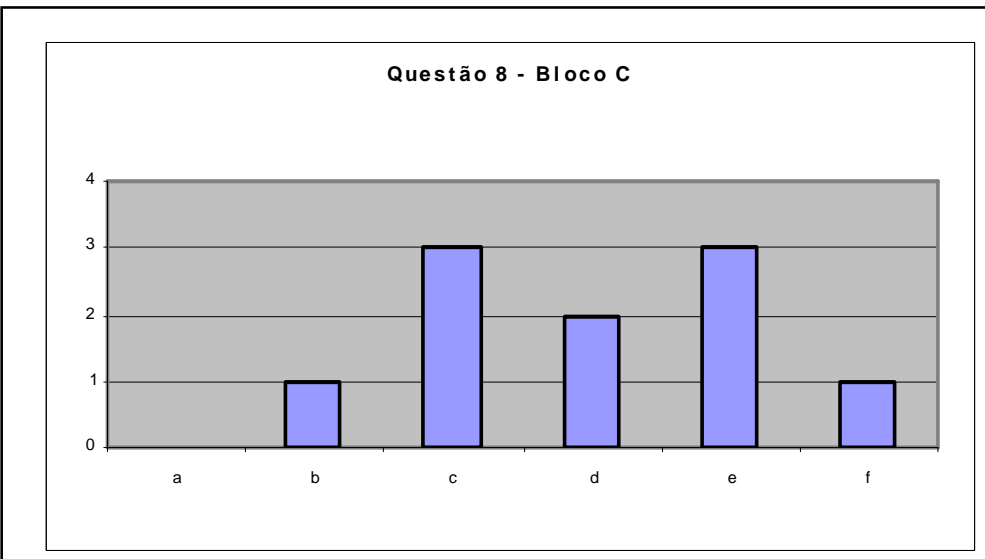

A gestão da manufatura contempla
os diversos ambientes resultantes dos
processos de mudança?
Esta questão avalia se a gestão da
manufatura das empresas está ciente e
ativa em relação às mudanças. Em uma
das empresas este quadro é muito
pequeno, em três há pouca percepção,
em duas delas isto acontece de forma
razoável, em três é grande e em uma é
muito grande a contemplação da gestão
da manufatura em relação aos
ambientes resultantes dos processos de
mudança.

Figura 31 - Distribuição das respostas à questão 8 do Bloco C.

Dentre as mudanças necessárias, uma delas seria a mudança na gestão das pessoas e isto acaba refletindo na área de recursos humanos. Segundo Forrester (1995), as mudanças que demandam do sistema de pessoal são incrivelmente grandes a partir da evolução da introdução da manufatura enxuta e das ferramentas do KAIZEN. Contratação de pessoal, treinamento, novas habilidades que o pessoal deve adquirir, têm necessidades diferentes quando comparamos o sistema da manufatura enxuta e os sistemas tradicionais de gestão das empresas. Na questão nove do bloco C ( Figura 32), foi perguntado às empresas se nas suas descrições de cargos do chão de fábrica, elas tinham critérios de competência e habilidades face as novas necessidades. As respostas obtidas nos mostram que sim, a maioria das empresas têm estes critérios, cinco dos respondentes afirmaram que em suas empresas estes critérios existem de forma grande, duas empresas responderam que isto acontece de forma muito grande. Apenas um dos respondentes informou que em sua empresa estas definições são pouco consideradas para os cargos do chão de fábrica. Foram obtidas mais duas respostas cujos respondentes afirmaram que os critérios de competência, conhecimento e habilidades são definidos razoavelmente para os cargos do chão de fábrica. Estes critérios contemplariam as demandas para deixar claro ao pessoal de chão de fábrica o novo papel, mais participativo, direcionado às habilidades para resolução de problemas, participação no desenvolvimento dos produtos, padronização do trabalho. $\mathrm{Na}$ área de recursos 
humanos de empresas, onde há as definições e critérios de competência e habilidades para o pessoal de chão de fábrica, existe uma freqüência grande de treinamentos voltados para manutenção, cuidados com a organização e limpeza, resolução de problemas e trabalho em times. Isto faz com que haja maiores e melhores resultados em seus programas de melhoria com conseqüência na eliminação de perdas e desperdícios.

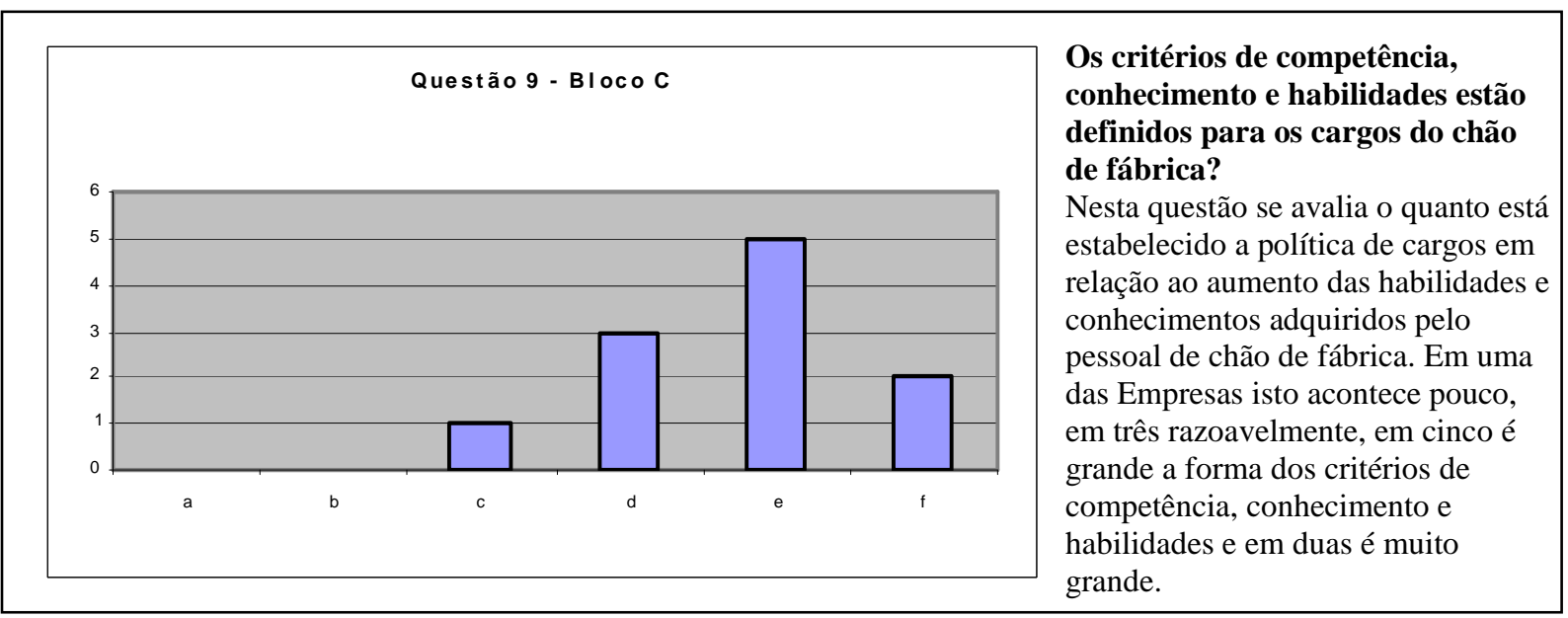

Figura 32 - Distribuição das respostas à questão 9 do Bloco C.

Em muitas empresas acontecem iniciativas de KAIZEN pontuais, fruto individual do trabalho de alguma gerência de área. Já em outras empresas os trabalhos de KAIZEN são estruturados de forma a ter uma espécie de grupo de condutores das implementações como apresentado no estudo de Brunet e New (2003) realizado no Japão. A primeira questão do bloco D (Figura 33) pergunta como é a condução destas atividades KAIZEN nas empresas pesquisadas. Dois dos respondentes informaram que em suas empresas há poucas atividades KAIZEN de forma estruturada, em outras duas estas atividades acontecem de forma razoavelmente estruturada, em outras três empresas seus respondentes afirmaram que em suas empresas as atividades KAIZEN têm grande estruturação e em três empresas as informações foram de que em suas empresas as atividades são muito estruturadas. As vantagens específicas em se estruturar as atividades do KAIZEN podem não ser evidentes, necessariamente é importante focar as atividades nos locais ou processos onde acontecem os desperdícios e perdas. Se nas empresas em que há pouca estruturação o alvo é certeiro pode-se estar garantindo a eficácia da atividade. 


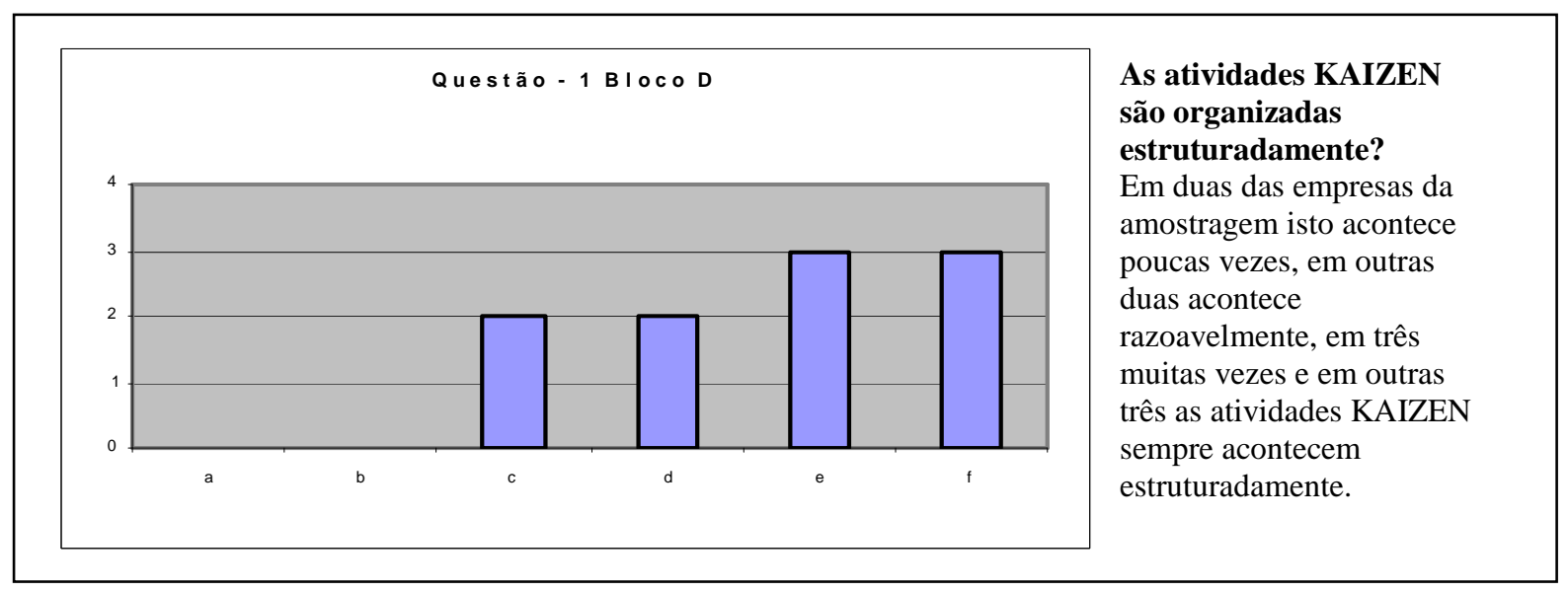

Figura 33 - Distribuição das respostas à questão 1 do Bloco D.

Historicamente o KAIZEN surgiu junto com a criação de um sistema de produção, mais tarde batizado de manufatura enxuta, para buscar e eliminar as perdas e desperdícios, mantendo, se possível, apenas as atividades que agregam valor ao negócio, tornando estas atividades que agregam valor, cada vez mais eficientes. Quando, o sistema Toyota de produção passou a ser divulgado no ocidente, principalmente através do livro The Machine that Changed the World (Womack et al., 1992), muitas empresas ocidentais procuraram se atualizar de acordo com os preceitos da manufatura enxuta. Como a maior parte destas empresas tem ramificações e subsidiárias ao redor do mundo, muitas vezes o trabalho se iniciou na matriz para depois ser transmitido às filiais. Em outros casos, o início das atividades de busca de melhoria contínua se deu por outro tipo de interesse, assim, a questão 2 do Bloco D (Figura 34) indaga qual foi o motivo do início das atividades do KAIZEN nas empresas pesquisadas. Nove das onze empresas respondentes à pesquisa responderam que o motivo do início das atividades KAIZEN foi o de se reduzir perdas em busca da manufatura enxuta, e isto é coerente com o surgimento do KAIZEN e da manufatura enxuta. Apenas um dos respondentes afirmou que as atividades KAIZEN em sua empresa se iniciaram porque a cúpula da empresa assim o queria. A outra resposta obtida foi que as atividades KAIZEN foram iniciadas para melhorar o clima organizacional. Resposta muito distinta daquilo que observa na literatura sobre a experiência das empresas sobre o assunto. Há um risco muito grande em se iniciar este tipo de atividade visando unicamente esta melhoria de clima interno, pois a mobilização de pessoas e recursos mesmo que pequenos não são coisas que se pode dispensar sem propósitos de crescimento ou de melhoria de resultados econômicos. Pode ser que 
nesta empresa as dificuldades geradas por um clima organizacional ruim estejam afetando estes resultados econômicos e que estas ações para melhorar este clima e com continuidade nas busca de eliminação das perdas tenham um efeito no todo.

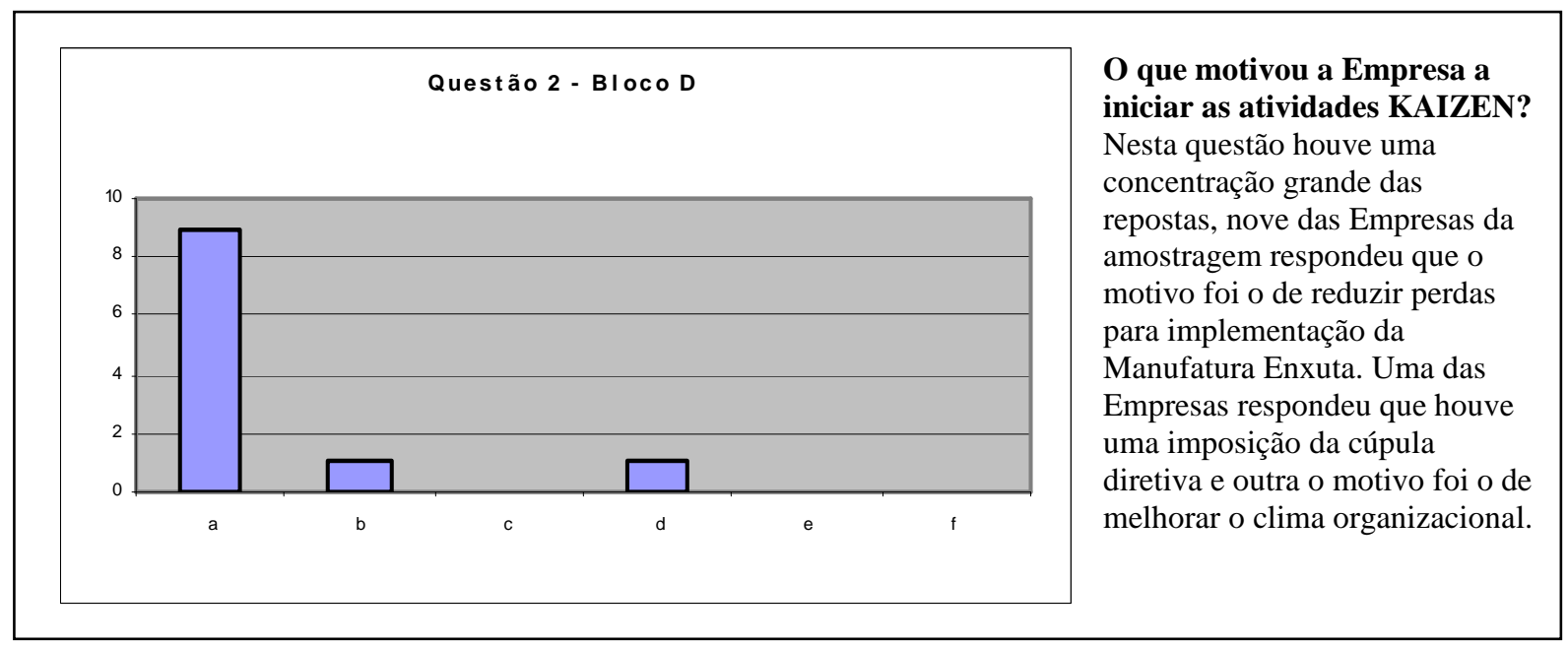

Figura 34 - Distribuição das respostas à questão 2 do Bloco D.

Em complementação à questão sobre os motivos de se iniciar as atividades do KAIZEN nas empresas foi colocada a questão três do bloco D (Figura 35) sobre quem tomou a liderança das iniciativas do KAIZEN. Foram obtidos apenas dois tipos de respostas a esta questão, uma delas informando que as atividades foram iniciadas pela alta direção em cinco empresas e os outros seis respondentes disseram que em suas empresas as iniciativas aconteceram com a liderança da média gerência. Este espectro de respostas nos mostra a existência de uma média gerência com autonomia suficiente para iniciar este tipo de programa, pode representar que nestas empresas o estilo de gestão é bastante participativo, não havendo a necessidade de que somente a alta direção exerça o papel de dar os rumos da empresa em termo de atividades estratégicas. Por outro lado este tipo de ocorrência pode indicar que as iniciativas de KAIZEN não tenham o apoio da alta direção e isto poderia ser um fator de sucesso para o programa. 


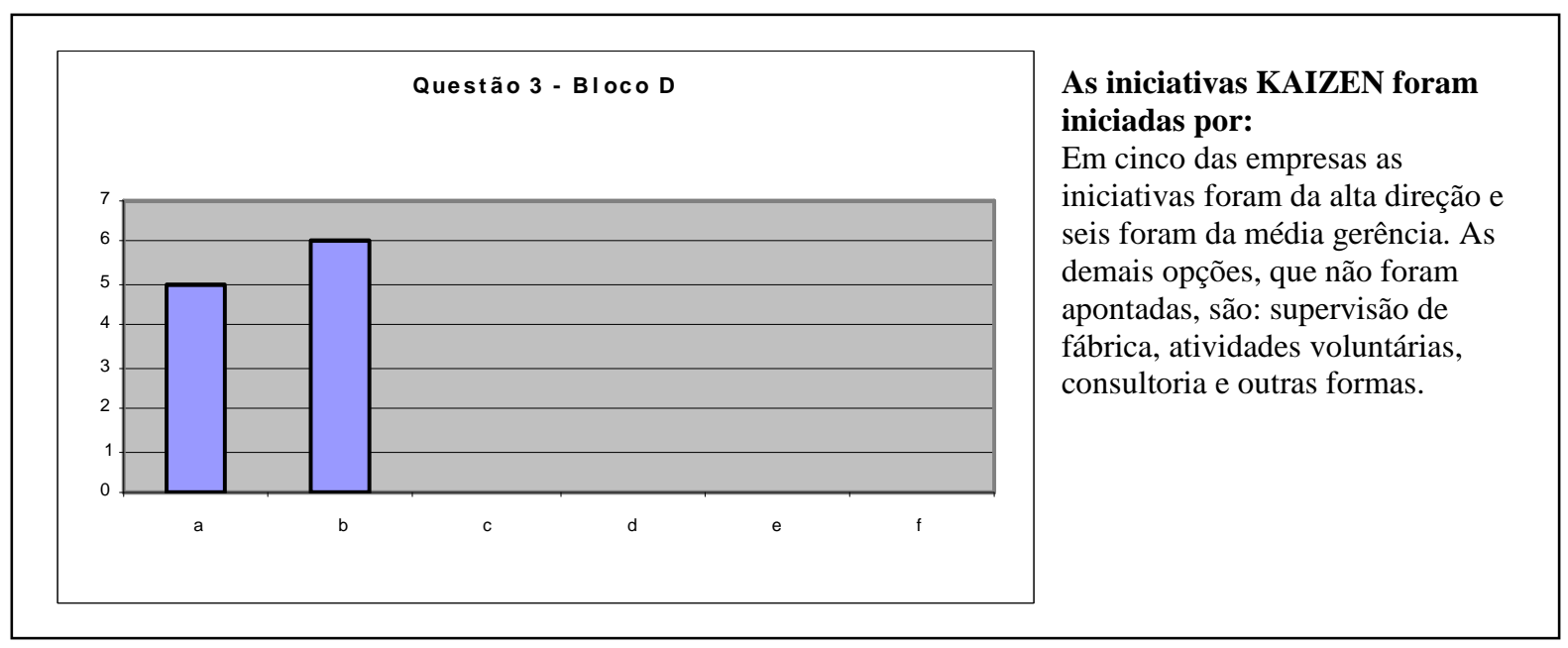

Figura 35 - Distribuição das respostas à questão 3 do Bloco D.

Dependo da amplitude e da estratégia que se quer dar ao programa KAIZEN há o direcionamento da divulgação dos conceitos do KAIZEN. Como usual, na maioria das empresas, este direcionamento se dá para a área de manufatura, mas já há exemplos de que a metodologia KAIZEN é utilizada em áreas administrativas, como as áreas financeiras e suprimentos e que a manufatura enxuta passa ser a filosofia enxuta, utilizada em diversos segmentos de atividades. A questão quatro do bloco D (Figura 36) foi colocada para se obter as informações da abrangência que se deu ao programa KAIZEN nas empresas participantes da pesquisa. Cinco respondentes afirmaram que em suas empresas houve divulgação para toda a empresa, um dos respondentes informou que a divulgação foi direcionada somente à manufatura, já em duas os conceitos foram divulgados a algumas áreas dentro da manufatura e outras duas apenas a uma área piloto. Outra resposta obtida nos diz que a divulgação está acontecendo conforme o andamento das atividades dentro da empresa, não havendo uma divulgação geral inicial à empresa. Este quadro de respostas nos mostra que há uma preocupação na maior parte das empresas, cinco respostas, em se divulgar os conceitos do KAIZEN à toda empresa em geral, e isto pode significar que haja o interesse e entendimento de que o KAIZEN traria benefícios não somente à manufatura, mas ao todo. 


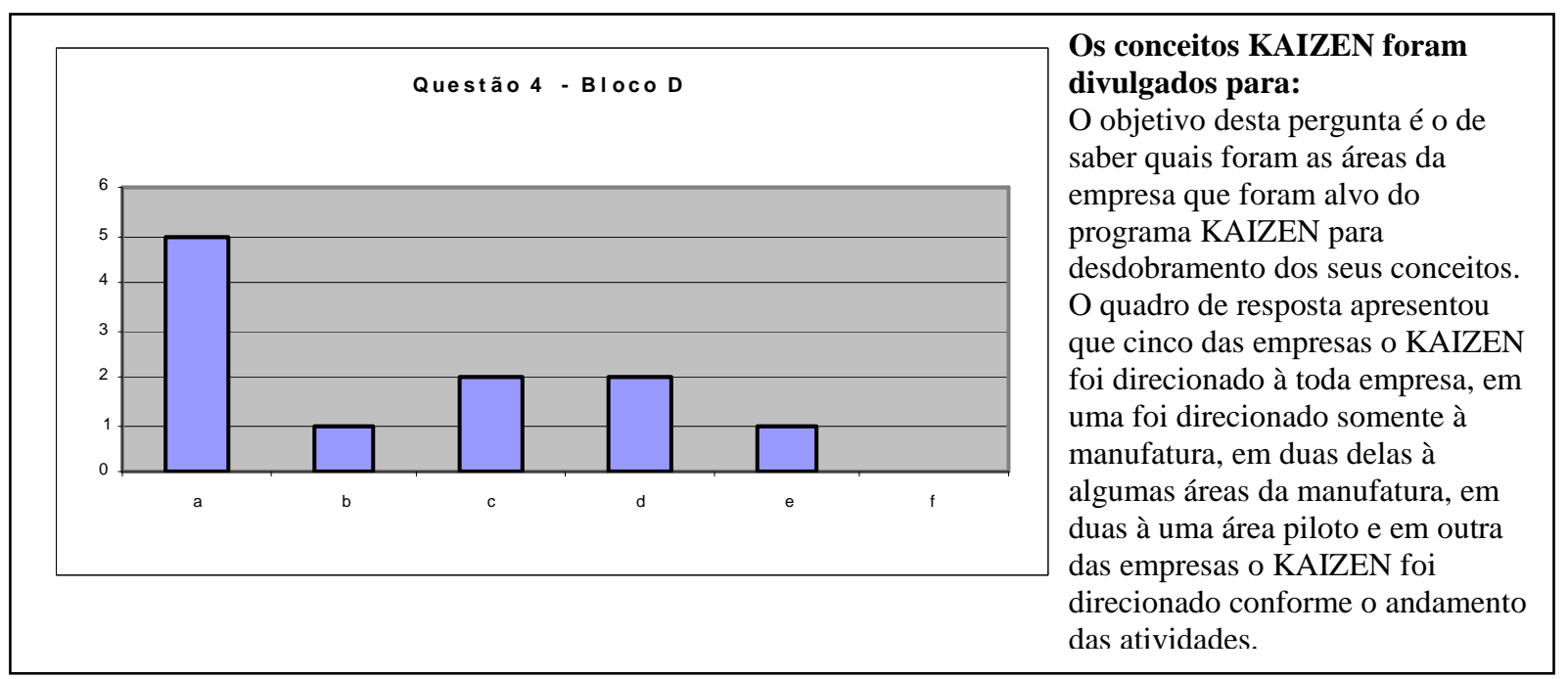

Figura 36 - Distribuição das respostas à questão 4 do Bloco D.

O sistema de sugestões de melhoria é uma das ferramentas muito utilizadas pelo programa KAIZEN (Imai, 1992), existem vários exemplos de sucesso de implementações do KAIZEN através desta ferramenta, como apresentado por Gondhalekar e Karamchandani (1994). Um dos fatores de sucesso seria o quanto se estende a participação do pessoal neste programa de sugestões. Na questão 5 do bloco D (Figura 37) foram obtidas respostas indicativas do andamento dos programas de sugestões de melhorias nas empresas participantes desta pesquisa. Cinco dos respondentes afirmaram que a participação do pessoal nas suas empresas é razoável, isto pode representar um andamento apenas uma pouco superior à média, mas poderia também representar algum sucesso neste programa ao comparar-se a outros dados vindos, por exemplo, da América do Norte onde a participação do pessoal neste programa é pequena (Gondhalekar e Karamchandani,1994). Duas empresas, através de seus respondentes, nos informaram que a participação é grande e outras duas que esta participação é muito grande, respostas que representam programas bem avançados e maduros, onde já se devem obter resultados e cujo pessoal deve estar bastante envolvido com estes resultados e benefícios provenientes do programa. Outras duas empresas devem estar com dificuldades em seus sistemas de sugestões de melhoria, uma resposta para pouca participação e outra muito pouca participação do pessoal. Pode haver a necessidade de um reforço na busca do envolvimento destas pessoas no programa, através, por exemplo, de mudanças no sistema de reconhecimento. 


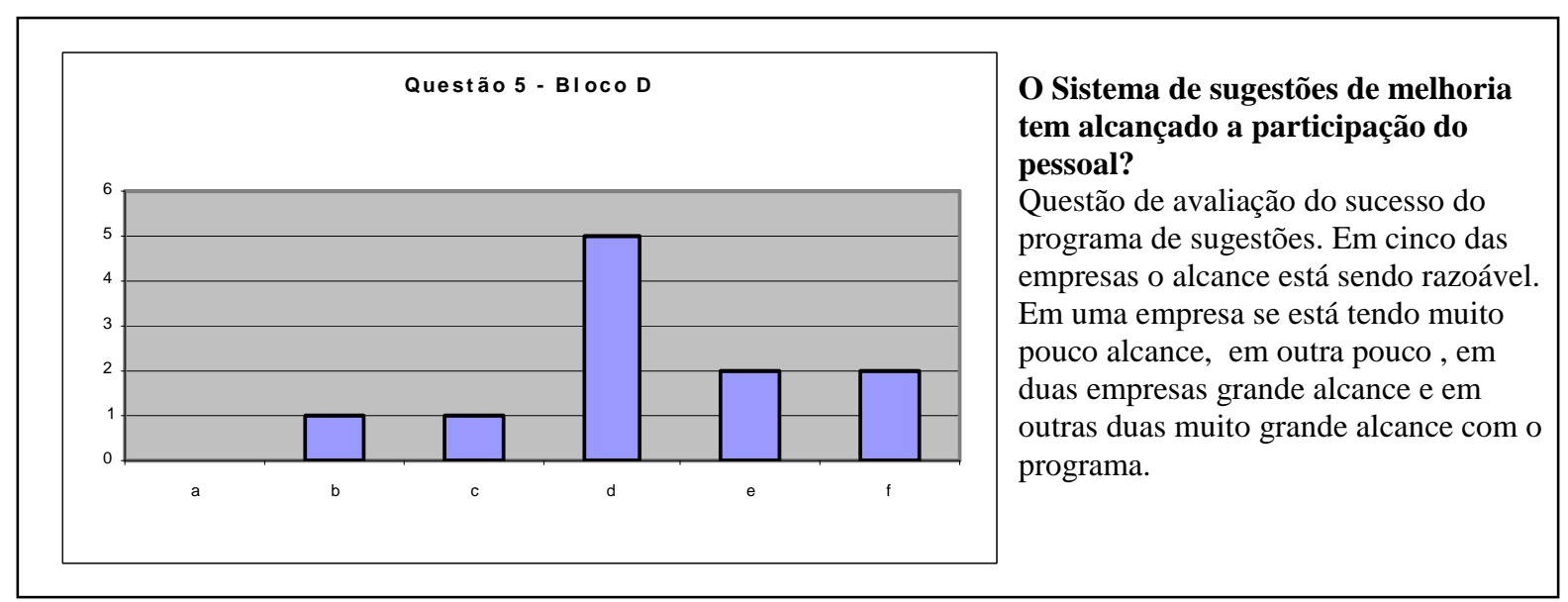

Figura 37 - Distribuição das respostas à questão 5 do Bloco D.

No conceito de Imai ( 1992), o KAIZEN é uma metodologia onde se abrigam as ferramentas Manutenção Produtiva Total(TPM), redução de tempo de set-up, mapeamento da qualidade, mapeamento do fluxo de processo, criação de operações padrão, programa de sugestões de melhoria. Estas ferramentas seriam utilizadas de acordo com as necessidades de melhoria, com qual perda ou desperdício se queira focalizar para reduzir ou eliminar, assim, a questão seis do bloco D (Figura 38) busca as informações de qual destas ferramentas seria a mais utilizada nas empresas pesquisadas. Pelo quadro de respostas recebido não há uma ferramenta em especial que possa ser considerada a mais utilizada, houve uma respostas para a Manutenção Produtiva Total (TPM), duas respostas para a redução de tempo de set-up, uma resposta para mapeamento da qualidade, duas respostas para mapeamento de fluxo de processo, uma resposta para a criação de operações padrão. Se pode destacar que três dos respondentes afirmaram que em suas empresas há a utilização de todas as ferramentas e isto pode ser uma demonstração da magnitude dos programas KAIZEN nestas empresas. Possivelmente a diversidade de respostas seja uma indicação de que não exista realmente uma ferramenta com utilização predominante e que este leque de ferramentas seja amplamente utilizado generalizadamente por todos que utilizam a metodologia KAIZEN. 


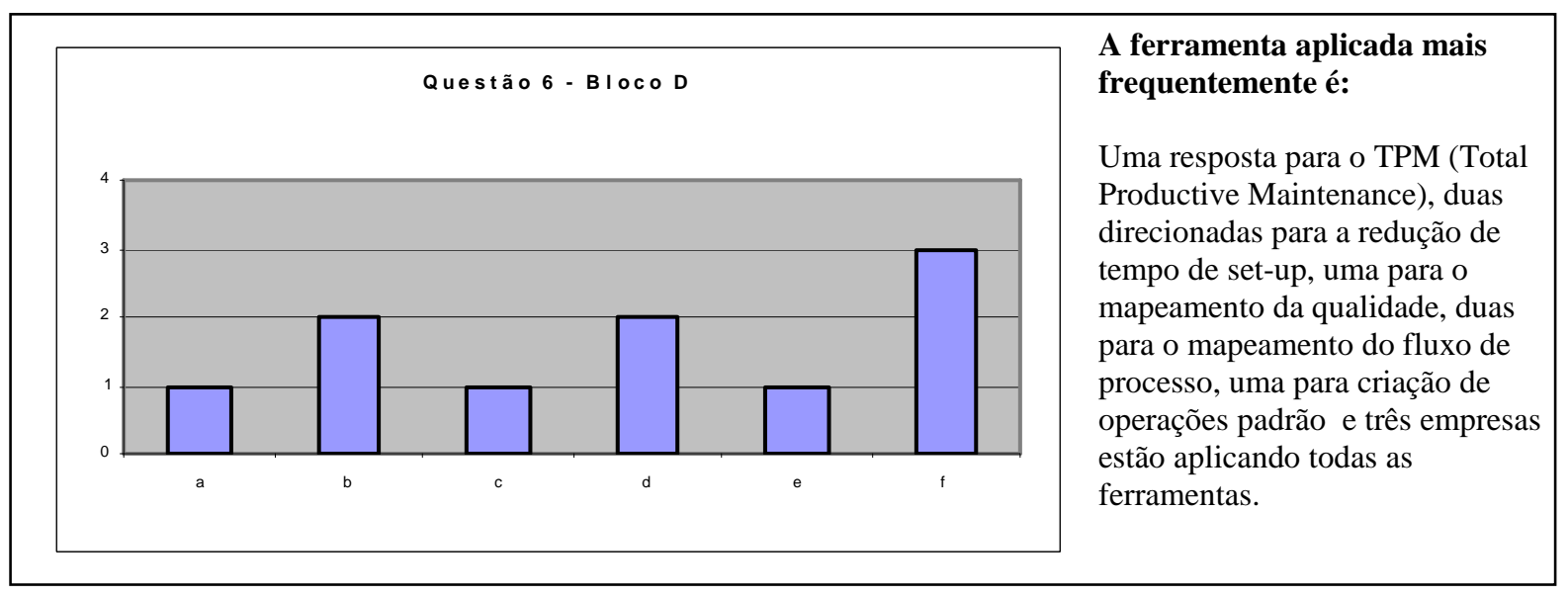

Figura 38 - Distribuição das respostas à questão 6 do Bloco D.

A participação da área de recursos humanos em um ambiente de mudanças é primordial ( Forrester, 1995), quando se fala da implantação de um programa como o da metodologia KAIZEN, vários aspectos dentro deste ambiente estarão mudando, podendo haver inclusive mudanças culturais. As necessidades de treinamento, solicitações de contrações com perfil de pessoal direcionado para as novas habilidades necessárias, sistemas de reconhecimento, relacionamento com os sindicatos em face do novo panorama de relações do trabalho são algumas da demandas a serem enfrentadas pela área de recursos humanos. Na questão sete do bloco D (Figura 39) foi verificado como é a participação da área de recursos humanos dentro dos programas KAIZEN e as respostas obtidas indicam que a maioria das empresas respondentes afirma que a participação é razoável, quatro respostas e grande, mais quatro respostas. Esta indicação pode significar que nestas empresas há, por parte da área de recursos humanos, uma preocupação especial com o programa KAIZEN, fazendo com que estas empresas possam ter o apoio necessário para empreender as mudanças necessárias e obter os resultados do KAIZEN. As demais respostas obtidas são dispersas, uma resposta informando que não há participação da área de recursos humanos, outra informando que há muito pouca participação e mais uma onde o respondente diz que há pouca participação da área de recursos humanos de suas empresas. Nas empresas conde a participação da área de recursos humanos não é significativa, pode haver uma falta de continuidade no programa KAIZEN pelo não atendimento às necessidades que o fator pessoal representa neste contexto. 


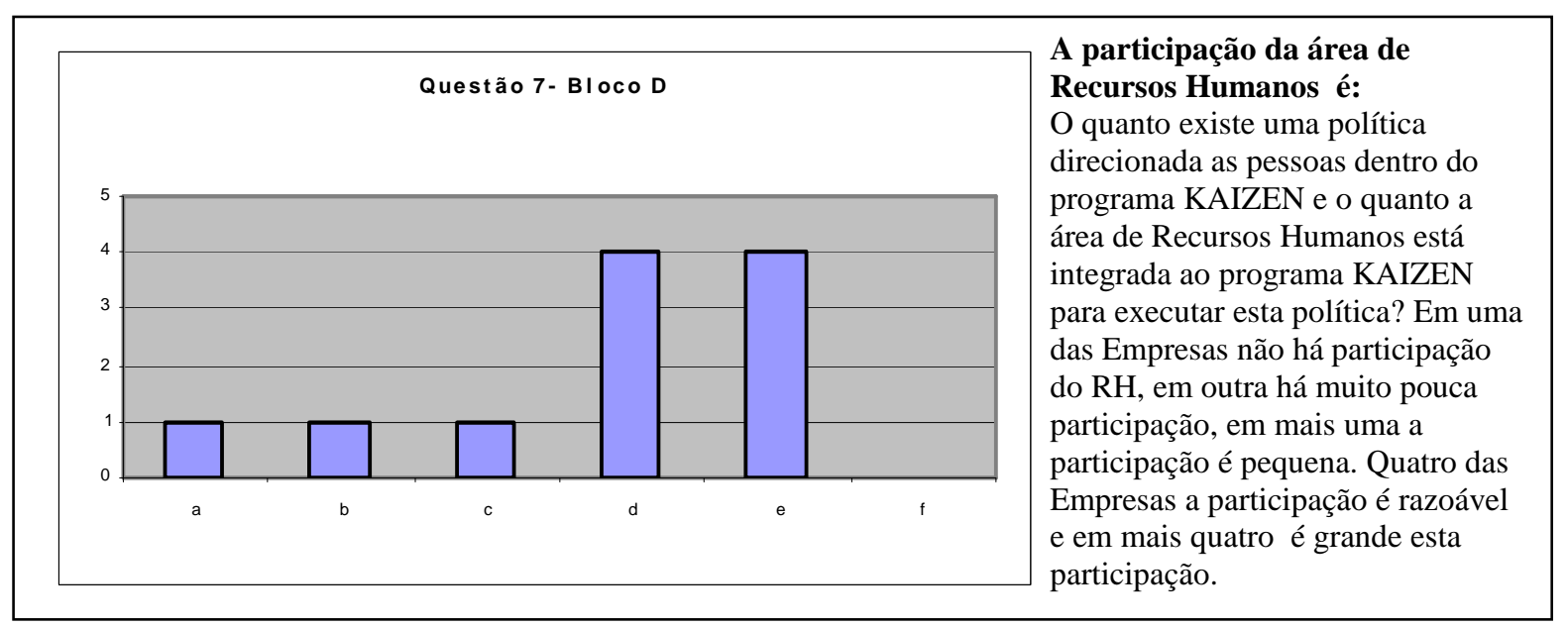

Figura 39 - Distribuição das respostas à questão 7 do Bloco D.

A condução das atividades KAIZEN dentro das empresas pode ser assumida de diversas formas, Imai (1992) sugere este se forme um pequeno comitê com especialistas para coordenar o andamento do processo, avaliando os resultados e implementando contra medidas quando necessárias. O interesse em se conhecer como as empresas conduzem seus programas KAIZEN seria para ter a informação em função dos resultados obtidos. Esta informação poderia ser utilizada pelos iniciantes no processo na qual poderiam espelhar os casos de sucesso. As respostas (Figura 40) obtidas dão um panorama onde há bastante diversidade nas formas e condução do programa, três respondentes informaram que nas suas empresas há um comitê diretivo reunindo vários departamentos, em duas das empresas foi recebida à informação de que há um coordenador exclusivamente dedicado ao assunto, a área de manufatura é a condutora dos trabalhos KAIZEN em três empresas, uma consultoria conduz as atividades em uma das empresas, em outra das empresas a condução não é estruturada e por último, um dos respondentes informa que a opção de condução em sua empresa não estava na lista. Destas respostas pode-se dizer que existem três formas principais de condução das atividades: através de um comitê heterogêneo, através de um coordenador dedicado ou através da organização existente na área de manufatura. Não se pode dizer qual seria a melhor forma de condução, para isto deveríamos analisar cada caso e verificarmos os resultados de cada modo de atuação em relação ao KAIZEN. 


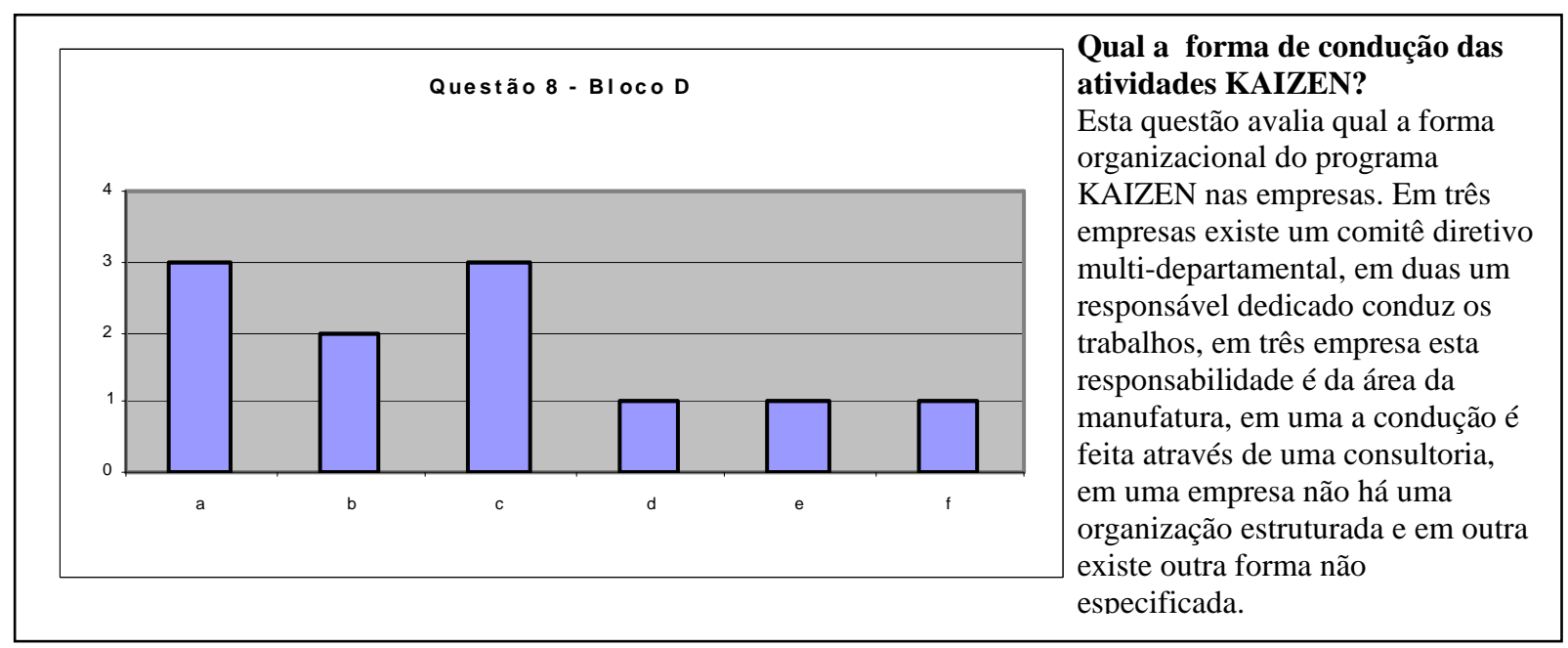

Figura 40 - Distribuição das respostas à questão 8 do Bloco D.

Já foi visto como é a participação do pessoal no programa de sugestões de melhoria através da questão cinco do bloco D (Figura 37), na questão nove do bloco D (Figura 41) a informação buscada é como os operadores, pessoal que opera as linhas de produção, participam do programa KAIZEN. Como mencionado por Imai (1992), a participação das pessoas é essencial para se obter sucesso no empreendimento KAIZEN, este grau de participação poderia ser até uma forma de indicador de desempenho do programa. As respostas obtidas poderiam nos dar um panorama sobre este assunto entre as empresas que participaram do levantamento. Assim, cinco empresas responderam que a participação dos operadores é grande e duas responderam que esta participação é muito grande e uma afirmou que esta é razoável. Neste grupo de empresas o programa KAIZEN poderia ser considerado em bom andamento, considerando-se o fator participação dos operadores, esta empresas devem ter uma boa organização das atividades KAIZEN, havendo talvez formas de incentivo a esta participação. Dois respondentes informaram que a participação dos operadores é pequena e uma outra empresa respondeu que não há participação dos operadores. Neste grupo de empresas o programa KAIZEN pode estar em sua fase inicial, os conceitos ainda não foram totalmente divulgados, pois caso contrário os programas nestas empresas estão em situação bastante delicada porque com pouca ou nenhuma participação dos operadores, não há como se evoluir com o KAIZEN, pode ser um momento nestas empresas que se deva fazer uma reavaliação de todo o programa para não desgastar e desacreditar o KAIZEN nestes locais. 


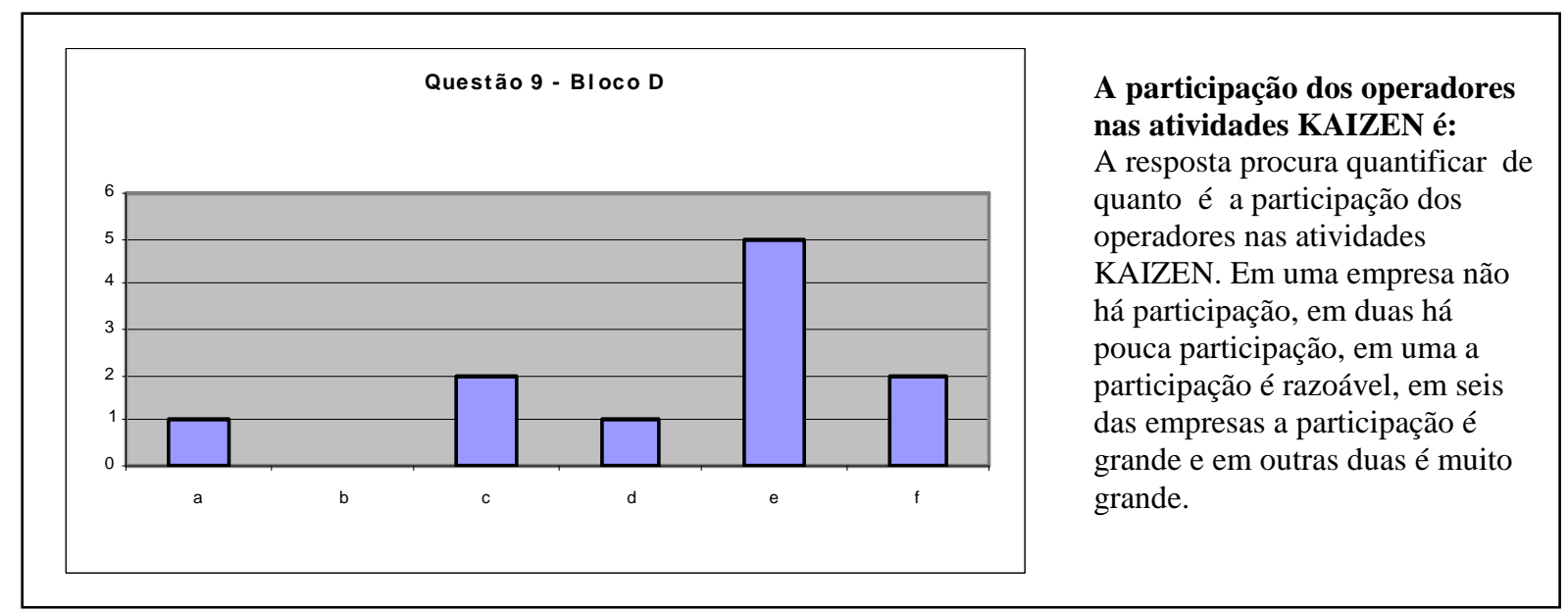

Figura 41 - Distribuição das respostas à questão 9 do Bloco D.

O aspecto cultural é algo muito importante em se tratando da metodologia KAIZEN, a maneira tradicional de fazer as coisas sofre muitas mudanças diante desta metodologia. As pessoas têm um papel diferente, há a valorização da criatividade, da valorização do grupo em detrimento ao individual, foco no processo, eliminação das diferenças entre pessoal da administração e operadores, novo encaminhamento para a análise e solução de problemas. A cultura da empresa muda com o advento do KAIZEN ou o sucesso do programa poderá estar comprometido e o poder organizacional para defender as rotinas é um gatilho para a falha na mudança (Forrester, 1995). Mas com um firme propósito e condução exemplar as mudanças acontecerão (Sommerville, 1995). A primeira questão do bloco $E$ (Figura 42) indaga se houve esta mudança de cultura nas empresas participantes do levantamento amostral. Foram obtidas respostas que indicam que houve mudanças, em diferentes níveis, em todas as empresas. Cinco respondentes afirmaram que a mudança cultural foi grande, em quatro empresas a mudança foi razoável e em apenas duas delas a informação foi de que houve uma mudança pequena. Como todas as empresas participantes têm em andamento programas KAIZEN, pois foi uma condição de seleção da população, seria esperado que houvesse realmente um quadro de mudanças culturais em todas elas e o espectro de respostas confirma a expectativa. Principalmente nas empresas com grandes mudanças culturais, há o sinal de um programa KAIZEN em estágio avançado, cujos resultados já podem estar sendo colhidos. 


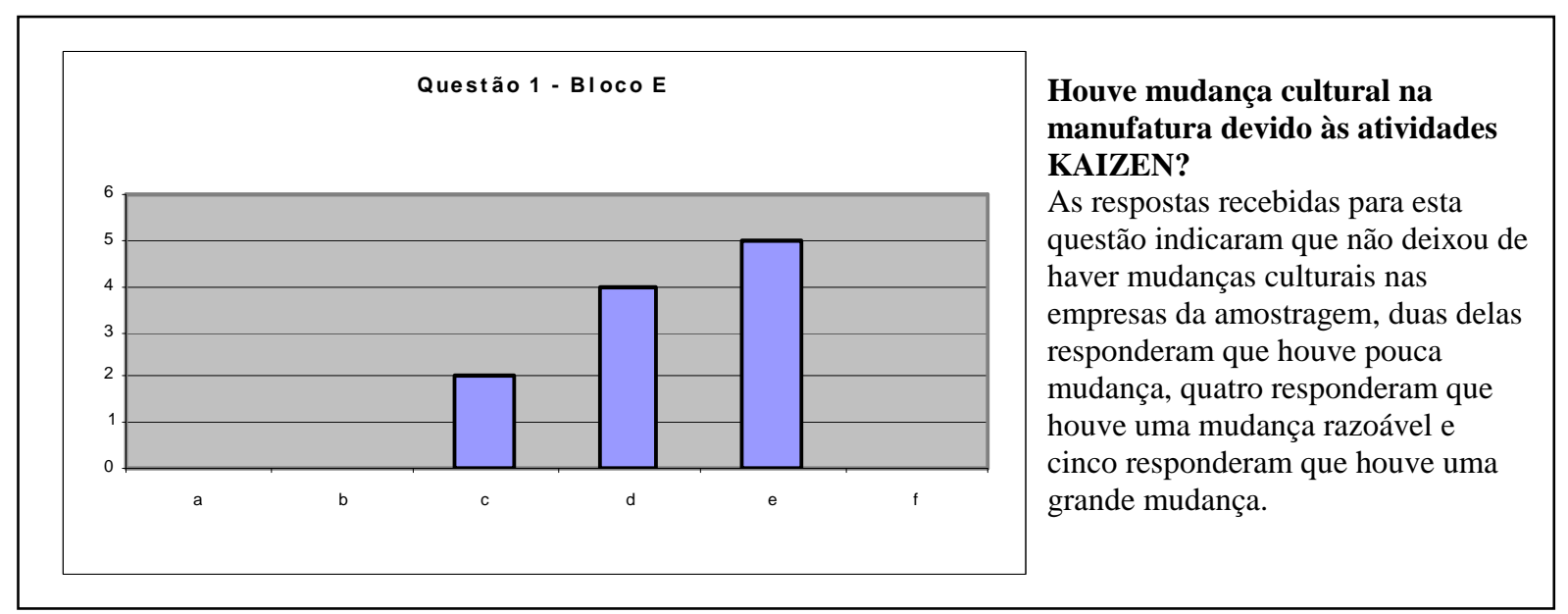

Figura 42 - Distribuição das respostas à questão 1 do Bloco E.

Outra questão importante e algo que se deve ter muito cuidado dentro do programa KAIZEN seria a necessidade de se evitar que as mudanças, a jornada em busca da manufatura enxuta cause um sentimento de ameaça ao pessoal. Lidar com este problema exige bastante tato dos condutores do programa, é importante lembrar quando do lançamento do programa e iniciadas as primeiras ações que o objetivo é o de melhorar o resultado da empresa através da eliminação das perdas e dos desperdícios. Eliminando ou reduzindo as atividades que não agregam valor, que o objetivo não é o de reduzir pessoal. A questão 2 do bloco $E$ (Figura 43) trata do assunto ameaça nas empresas desta pesquisa, as respostas recebidas apresentam um quadro onde não há evidencias de que haja este sentimento de ameaça entre as empresas respondentes. Quatro respostas a afirmação foi de que não houve este sentimento, em outras quatro houve muito pouco sentimento de ameaça e em três das empresas o sentimento de ameaça foi pequeno. Estas respostas podem ser um indicativo de que a implementação dos programas KAIZEN nestas empresas aconteceu de forma cuidadosa no sentido de se evitar este sentimento. Os coordenadores foram cuidadosos quando da passagem dos conceitos e as primeiras ações aconteceram de forma a dissipar as dúvidas que surgem em termos de que seria mais um programa para se eliminar postos de trabalho e sim eliminar os desperdícios e perdas. 


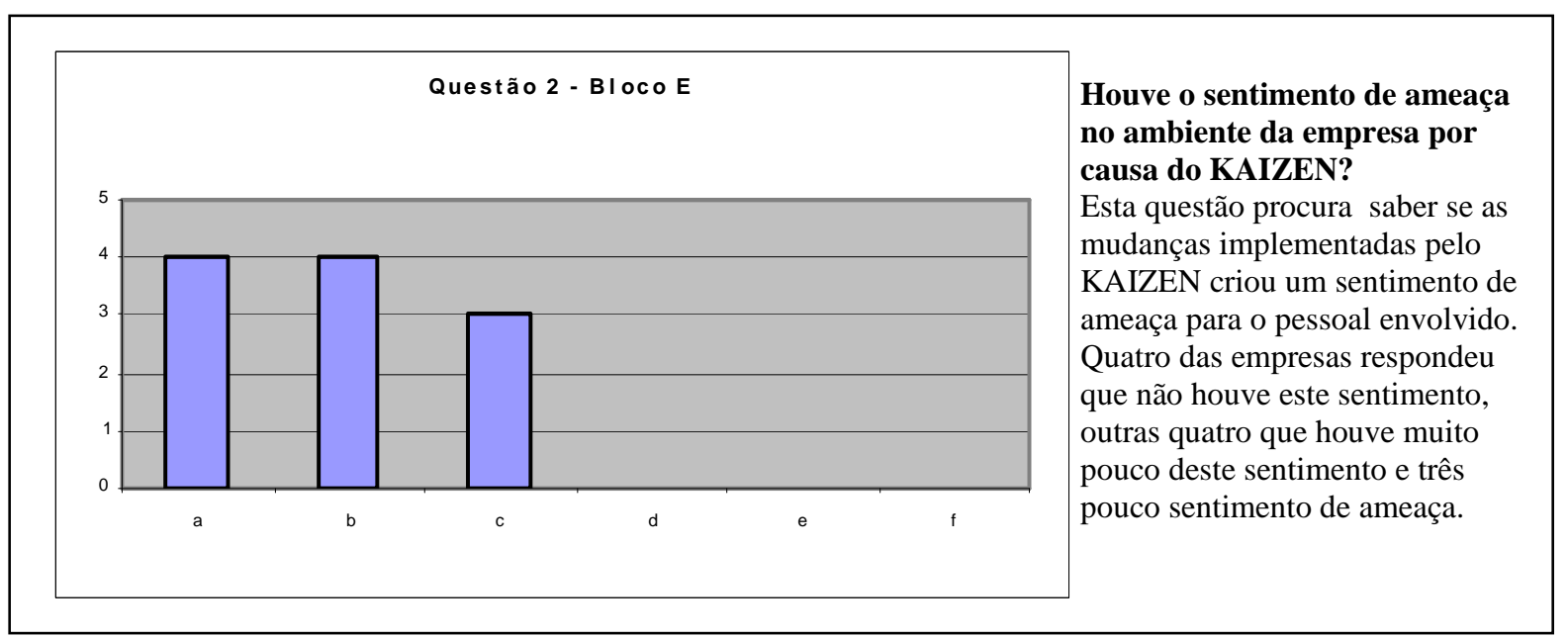

Figura 43 - Distribuição das respostas à questão 2 do Bloco E.

Afinal, o programa KAIZEN dá resultados palpáveis, ou seja, resultados de ganhos econômicos às empresas? De forma indireta, em relação aos seus faturamentos, a questão três do bloco E (Figura 44), pergunta às empresas participantes desta pesquisa quais são os ganhos reais advindos do programa KAIZEN. Com o programa KAIZEN, as ferramentas para se eliminar ou reduzir as perdas e desperdícios, as empresa querem obter redução de seus custos, mais flexibilidade no atendimento às necessidades dos clientes e com isto ter vantagens em um mercado cada vez mais competitivo. Principalmente em se tratando de um tão competitivo como este ao qual pertencem as empresas participantes desta pesquisa. As respostas recebidas mostram que em cinco da empresas o resultado financeiro obtido com o programa é algo entre $1 \%$ e $3 \%$ do faturamento destas empresas, valor bastante considerável quando sabemos as dificuldades que as empresas têm para alcançarem um retorno acima de $10 \%$ em seus demonstrativos financeiros. Nas demais respostas recebidas em quatro empresas os ganhos não foram medidos, em uma das empresas não houve ganho e em outra os ganhos foram inferiores a $1 \%$ de seu faturamento. Pode ser que as empresas em que os ganhos não foram medidos estejam em estágios iniciais do programa, fases onde há a formação dos conceitos, treinamento de pessoal e que ainda seria cedo para contabilização de resultados. No caso da empresa onde não houve ganho nenhum se precisaria obter mais informações do estágio em que se encontra o programa KAIZEN em suas instalações. 


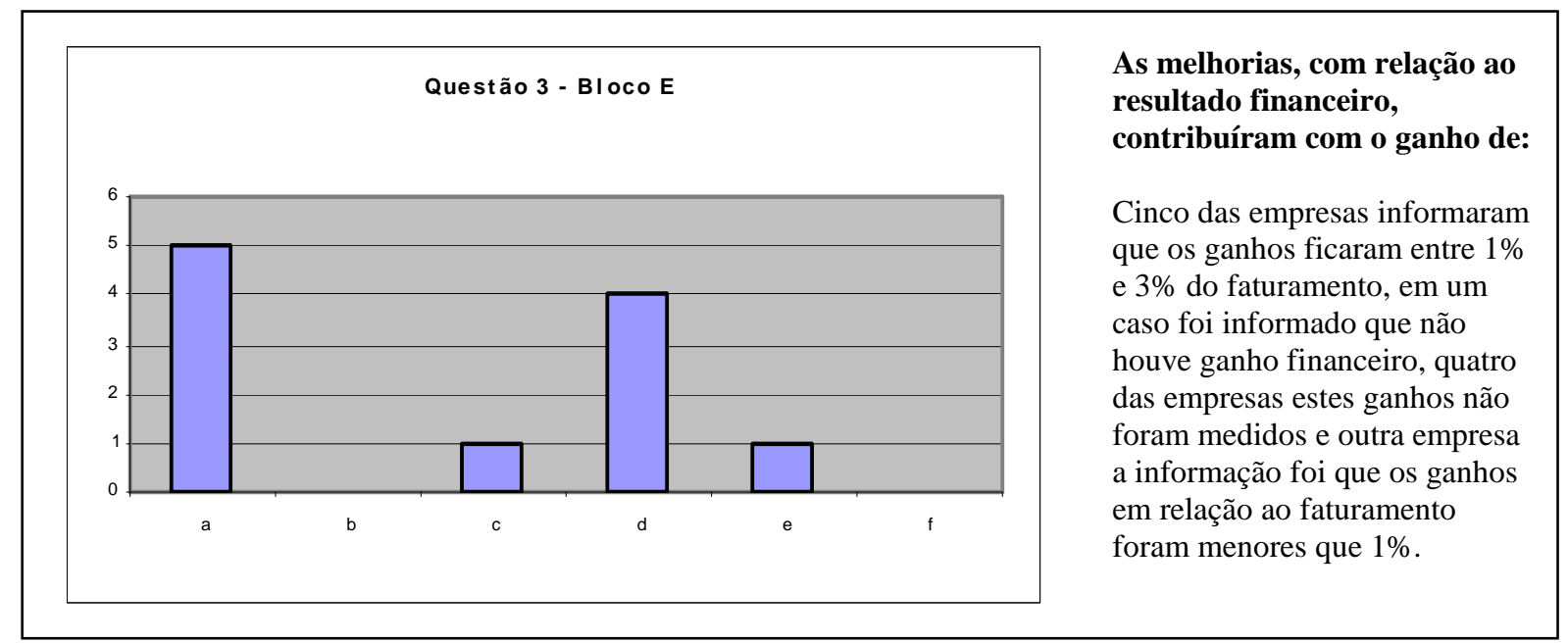

Figura 44 - Distribuição das respostas à questão 3 do Bloco E.

Para se conhecer os resultados referentes a uma atividade é necessário haver um método de contabilização dos ganhos e despesas referentes especificamente ao programa que se quer avaliar. Normalmente não se dá importância a esta tarefa, mas é uma maneira de reforçar o comprometimento de cima para baixo aos processos (Hiromoto, 1988). A questão 4 do bloco E (Figura 45) pergunta qual a forma que se está contabilizando as atividades KAIZEN nas empresas participantes da pesquisa e se obteve um panorama que não mostra uma predominância grande de um método. Três respondentes informaram que em suas empresas foi criada uma conta específica para se contabilizar as atividades do KAIZEN e outros quatro informaram que esta contabilização é feita por pessoal específico para este fim. Nestes dois grupos de empresas parece haver uma preocupação maior na obtenção de dados confiáveis a respeito dos resultados das atividades do programa KAIZEN. Esta preocupação pode ser em decorrência de um bom planejamento do programa onde se espera ter e demonstrar claramente o que se está conseguindo. Em outro grupo de respostas para a questão aparece a informação que em duas empresas se contabilizam os gastos na conta da área onde se está aplicando o KAIZEN e em outras duas a informação é que não uma contabilização específica para este fim. Neste grupo há um rigor menor na obtenção de dados para avaliação do programa, talvez estas empresas ainda estejam estruturando seus programas KAIZEN. Ainda não há uma preocupação com a contabilização dos ganhos a serem alcançados, no entanto, à medida que o programa avançar teria que ser desenvolvido um sistema de contabilização para acompanhar o desempenho das atividades KAIZEN sob risco de haver uma desmotivação dos participantes por falta de informações de resultado. 


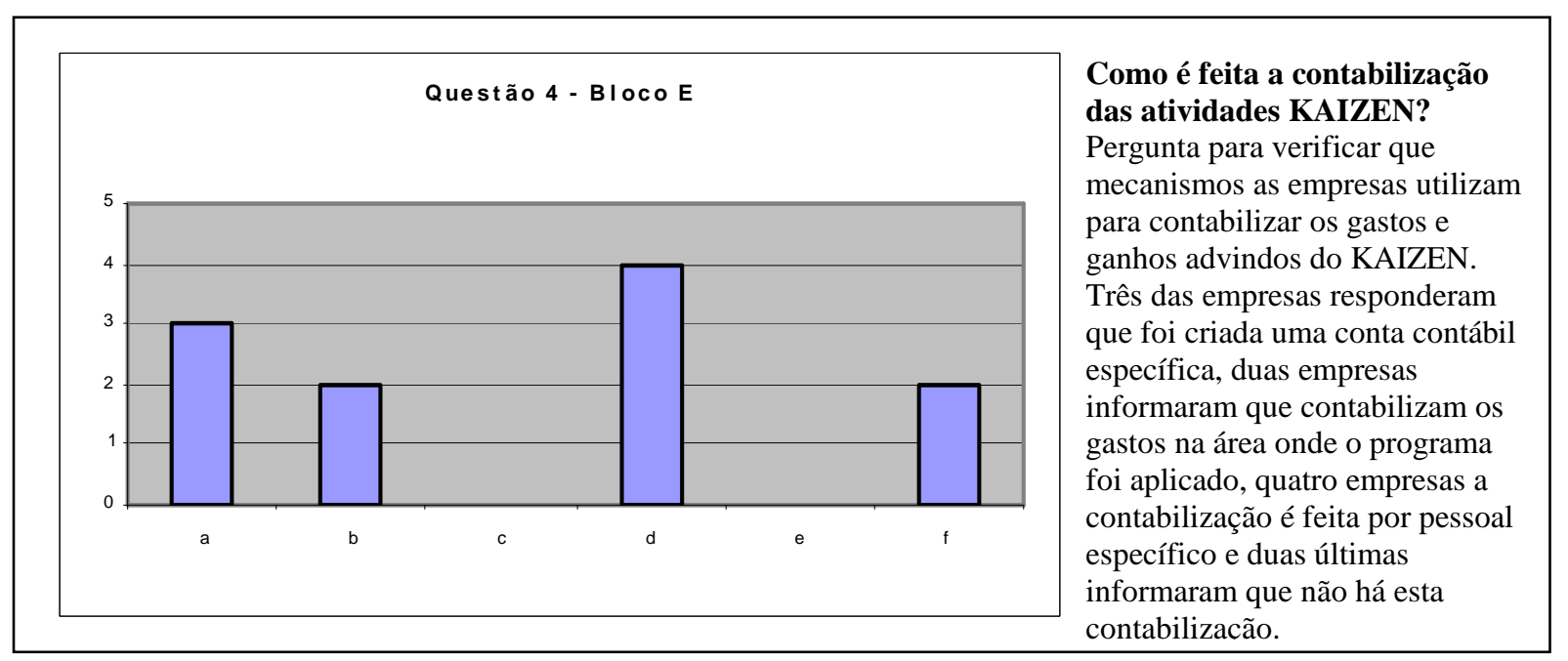

Figura 45 - Distribuição das respostas à questão 4 do Bloco E.

Um dos resultados que se espera do programa KAIZEN seria a melhora da motivação do pessoal, pois neste programa há a participação efetiva de todos nas ações e resultados, que serão compartilhados, além da liberdade que se cria para as iniciativas de melhoria. O próprio princípio de trabalho em times aumentaria esta motivação, porque as pessoas querem trabalhar bem suportando umas as outras (Clifford e Sohal, 1998). A questão cinco do bloco E ( Figura 46) pergunta se esta motivação foi melhorada nas empresas desta amostragem, já que todas têm programas KAIZEN em andamento. As Respostas apresentadas foram que no mínimo houve uma melhoria razoável na motivação do pessoal com as atividades KAIZEN, três empresas responderam que esta a melhoria foi razoável. As demais empresas responderam que houve uma grande melhoria de motivação, sete respostas, e em uma das empresas este aumento de motivação foi muito significativo. Tal panorama no diz que os resultados financeiros, diretamente contabilizados ou não, não sejam evidentes, há um aumento de motivação na empresa que utiliza a metodologia KAIZEN. Isto pode capitalizar ganhos às empresas em suas atividades normais que não são creditados ao programa KAIZEN, mas, são decorrentes de que sua força de trabalho está mais motivada, se comprometendo mais com as atividades e resultados da empresas para a qual trabalha. 


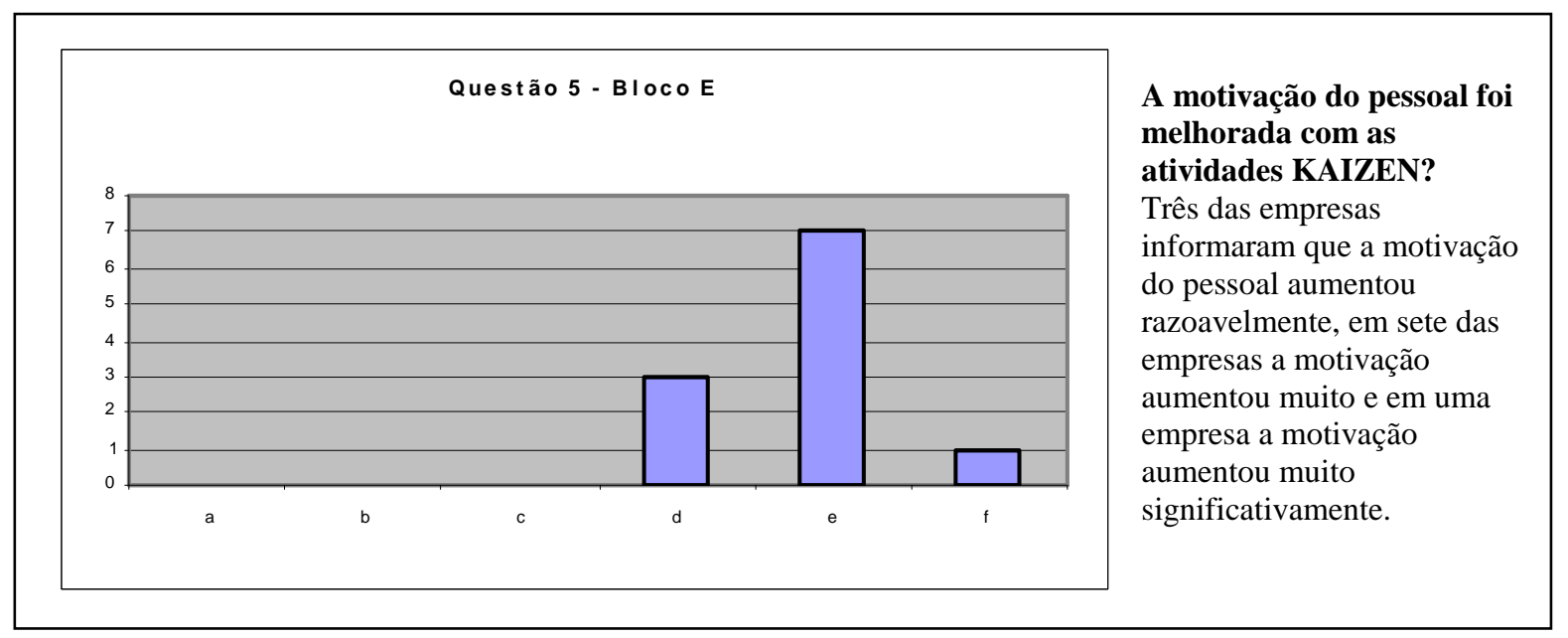

Figura 46 - Distribuição das respostas à questão 5 do Bloco E.

Uma vez alcançados os objetivos colocados em cada passo do programa KAIZEN, utilizando qualquer uma das ferramentas, existem os trabalhos de manutenção dos ganhos. Por exemplo, em uma redução de tempo de set-up alcançada, há o receio de se perder aquilo que se acabou de ganhar, pois pode ser difícil manter estes ganhos. Na questão seis do bloco E (Figura 47) foi perguntado se as empresas da amostragem têm dificuldades para manter os ganhos obtidos através das atividades KAIZEN. Em apenas uma das empresas o respondente afirmou não haver dificuldades de manutenção dos ganhos e em três pouca dificuldades, nestas empresas, onde a manutenção dos ganhos relativos às atividades KAIZEN não chega a ser um problema. Deve existir um ambiente onde a cultura, já voltada para o melhoramento contínuo, faz com que as pessoas tenham atitude suficiente para não permitir que haja retrocessos. Em outro grupo de respostas quatro respondentes informaram que há uma dificuldade razoável para manutenção dos ganhos, dois que há muita dificuldade e um respondente informando que há uma dificuldade significativa na manutenção dos ganhos. Este grupo de respostas pode significar que nestas empresas onde há mais dificuldades para manter aqueles ganhos resultantes das atividades do KAIZEN, ainda haja resistência às mudanças. Aquela força que faz com que as pessoas queiram manter suas rotinas, independente se a nova situação trará melhores resultados para si e para a empresa. 


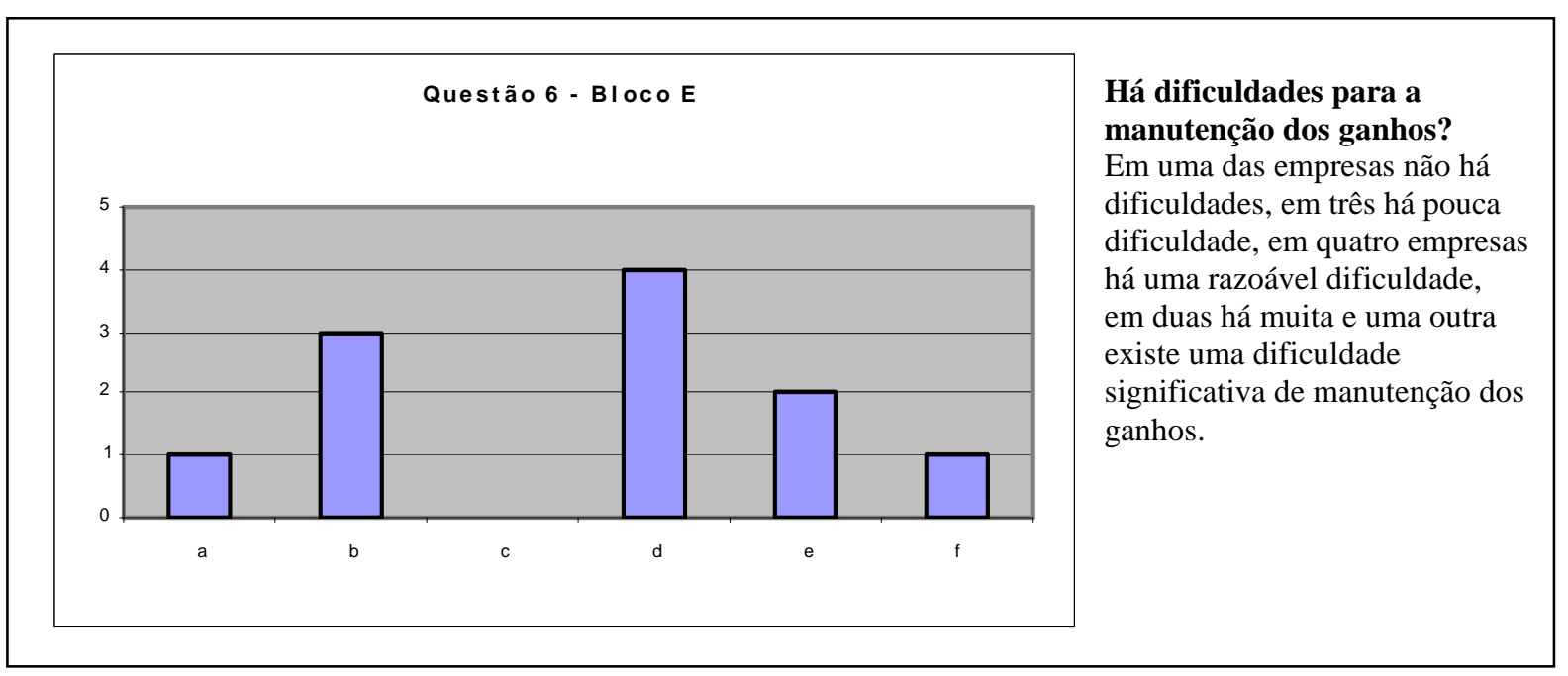

Figura 47 - Distribuição das respostas à questão 6 do Bloco E.

O número de fatores para o sucesso de um programa KAIZEN pode ser muito diverso, mas, alguns destes fatores são mais citados. A partir destas informações foram colocadas na questão sete do bloco E (Figura 48) opções para que os respondentes informassem qual destas opções seria o fator que mais influencia o bom andamento do programa KAIZEN em suas empresas. Brunet e New ( 2003) em seu estudo sobre o KAIZEN apontaram que, no Japão, os fatores comuns entre as empresas que têm sucesso em seus programas são mútuo contrato entre empregados e empregadores em termos de segurança em seus trabalhos, compartilhamento de ganhos, orientação de trabalhos em time em metas anuais. São diferentes daquilo que se pensa possa conduzir o sucesso em implementações no Brasil, pois nossa realidade é diferente. As respostas obtidas indicam que o principal sucesso informado pelos respondentes sobre a realidade em suas empresas é a participação da alta gerência, esta resposta pode significar que a força de trabalho nestas empresas. A partir da participação da alta gerência nas atividades KAIZEN, entenda que todos estão comprometidos com o programa, não sendo mais um tema de discursos de uns e trabalho para outros. Também, com a participação da alta gerência, há uma visualização mais clara do andamento do programa pelos executivos da empresa, podendo conduzir alterações de rumo quando necessário. Outros respondentes informaram que o fator de sucesso seria a existência de recursos disponíveis, com uma resposta, planejamento, uma resposta, estrutura de coordenação, duas respostas e apoio da alta direção com mais uma resposta. 


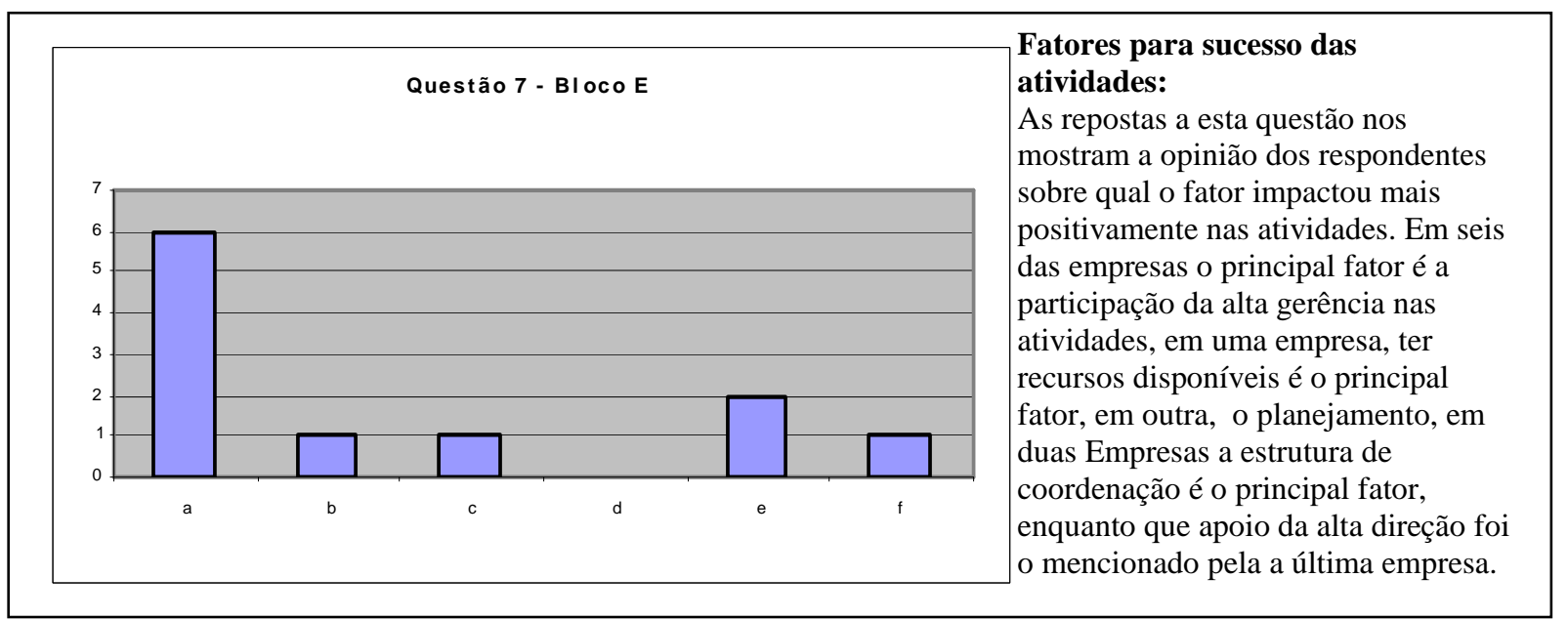

Figura 48 - Distribuição das respostas à questão 7 do Bloco E.

Os programas KAIZEN têm que ser sustentados, por esta razão foi colocada a questão oito do bloco E (Figura 49). Os cuidados para que o programa não se dissolva não tive uma resposta preponderante, de acordo com os respondentes desta pesquisa, três informaram que o principal cuidado que se tem em suas empresas é a procedimentação das alterações criadas pelo KAIZEN, dois informaram que em suas empresas se cuida do KAIZEN através de verificações periódicas, outros três respondentes afirmaram que o envolvimento contínuo do pessoal do chão de fábrica nas atividades do KAIZEN garante a sustentação de seus programas e mais três dizem que o monitoramento da alta direção cuida para que o programa KAIZEN se sustente em suas empresas. Como houve uma dispersão nos tipos de cuidados para sustentação do KAIZEN nas empresas, poderia ser dito que, talvez, o conjunto de cuidados apontados seja a maneira mais eficaz de cuidar para que um programa desta importância se sustente.

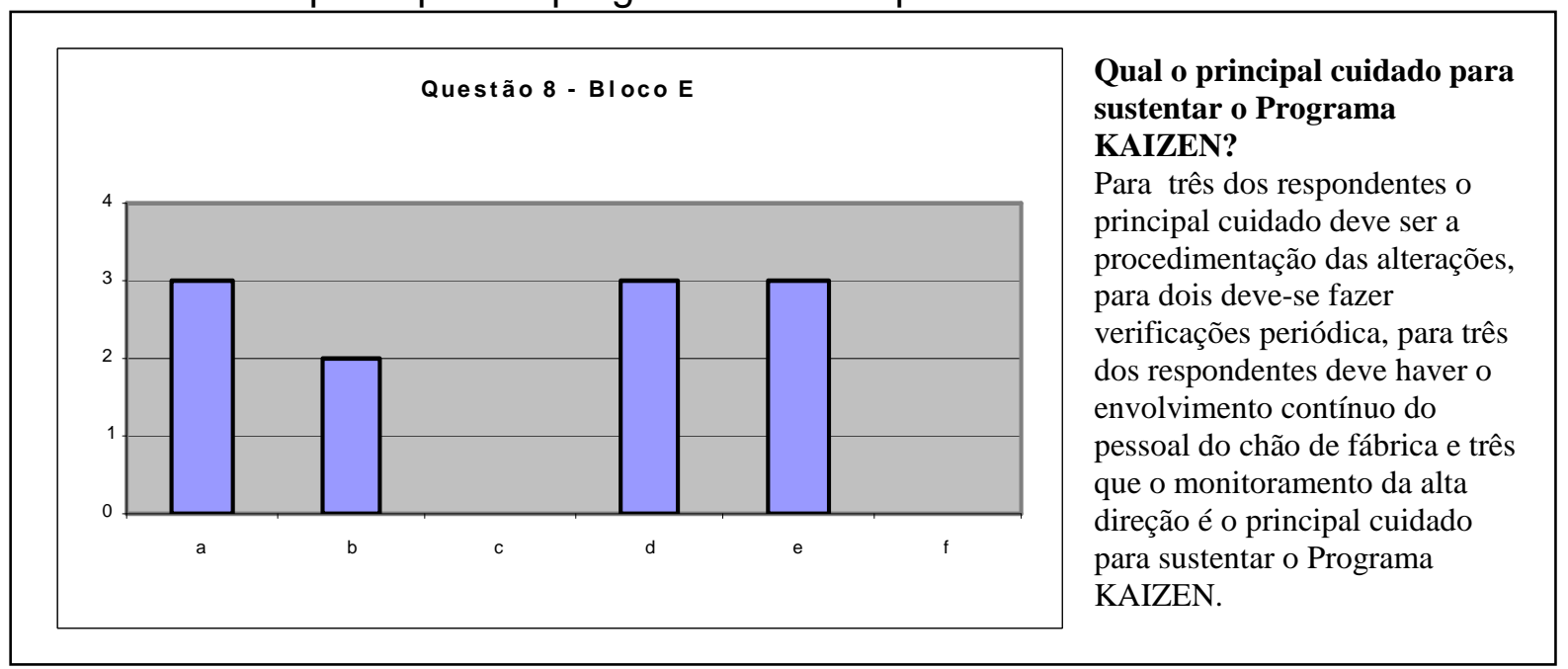

Figura 49 - Distribuição das respostas à questão 8 do Bloco E. 


\section{DISCUSSÃO}

Este capítulo traz a discussão sobre os resultados obtidos pelo levantamento amostral e a relação destes resultados com os objetivos propostos inicialmente.

O construto definido neste trabalho é o de que a metodologia KAIZEN reduz as perdas na Manufatura e a proposição é a de que esta metodologia produz resultados diretos no faturamento das Empresas onde ela é aplicada. Considerando que a resposta a esta questão é afirmativa, em quais condições se obtém sucesso?

Foram colocados, também, os objetivos abaixo:

- Como está a utilização da metodologia KAIZEN nas empresas?

- Qual é o entendimento que se tem do tema?

\subsection{Resultados das empresas que utilizam a metodologia KAIZEN}

De acordo com as respostas a respeito dos ganhos financeiros obtidos através das melhorias podemos dizer que sim, a aplicação da metodologia afeta diretamente o resultado financeiro das empresas que a utilizam. Dentre as onze empresas pesquisadas, cinco obtiveram ganhos que ficaram entre $1 \%$ e $3 \%$ de seus faturamentos e outra com ganhos, mas inferiores a 1\%. Este quadro é bastante revelador, pois está-se avaliando uma amostragem bem representativa das empresas de autopeças que aplicam a metodologia. Quando se lida com um ambiente onde a concorrência é demais acirrada, em que os preços são fortemente condicionados pelo mercado, os ganhos, por menores que possam ser, são bastante considerados. As margens de lucro neste tipo de atividade são muito estreitas e com as ferramentas para se eliminar ou reduzir as perdas e desperdícios, as empresas obtêm menores custos, mais flexibilidade no atendimento às necessidades dos clientes. É considerado, então, que os resultados que estas empresas indicaram são muito positivos e que, por si, justificariam os esforços necessários para aplicação da metodologia KAIZEN. Dentro das respostas recebidas há empresas onde não há a contabilização das atividades do programa KAIZEN. Nestas empresas podem estar 
acontecendo resultados tão positivos quanto aqueles das empresas onde os ganhos são registrados, mas também pode ser que as empresas estejam em estágios iniciais do programa, quando não há ainda a possibilidade de se dizer que as reduções de perdas e desperdícios já estejam acontecendo.

\subsection{Condições para obtenção dos resultados positivos}

Pelos resultados obtidos pela pesquisa, a metodologia KAIZEN aplicada nas empresas de autopeças produz resultados positivos no aspecto financeiro, mas é importante a discussão sobre quais são as condições para obtenção destes resultados.

A motivação do pessoal é um dos fatores que pode influenciar o bom andamento de um programa como o da metodologia KAIZEN, também se pode considerar que este fator seja um dos resultados das próprias atividades desenvolvidas pelo programa. Na questão sobre o aumento de motivação do pessoal quando das atividades KAIZEN, as respostas mostraram que houve um aumento desta, de razoável a muito grande. Assim, pode-se afirmar que há uma duplicidade de implicações em relação à motivação do pessoal nas empresas que aplicam a metodologia KAIZEN. Há uma realimentação, pois a metodologia aumenta a motivação do pessoal e esta motivação implica na obtenção de redução de perdas e desperdícios de maneira eficaz. Outras considerações importantes em relação ao fator pessoal seriam (Figura 50):

- A indicação da mudança cultural ocorrida nas empresas que aplicam a metodologia, como indicado pelas respostas a esta questão. A maior parte das empresas participantes da pesquisa teve uma razoável ou grande mudança cultural (82\% dos respondentes).

- A demonstração de não haver o sentimento de ameaça, em relação às ações implementadas pelo programa KAIZEN, no ambiente da Empresa, pois quando são verificadas as respostas, $100 \%$ das empresas respondentes disseram que houve pouco, muito pouco ou nenhum sentimento de ameaça. 


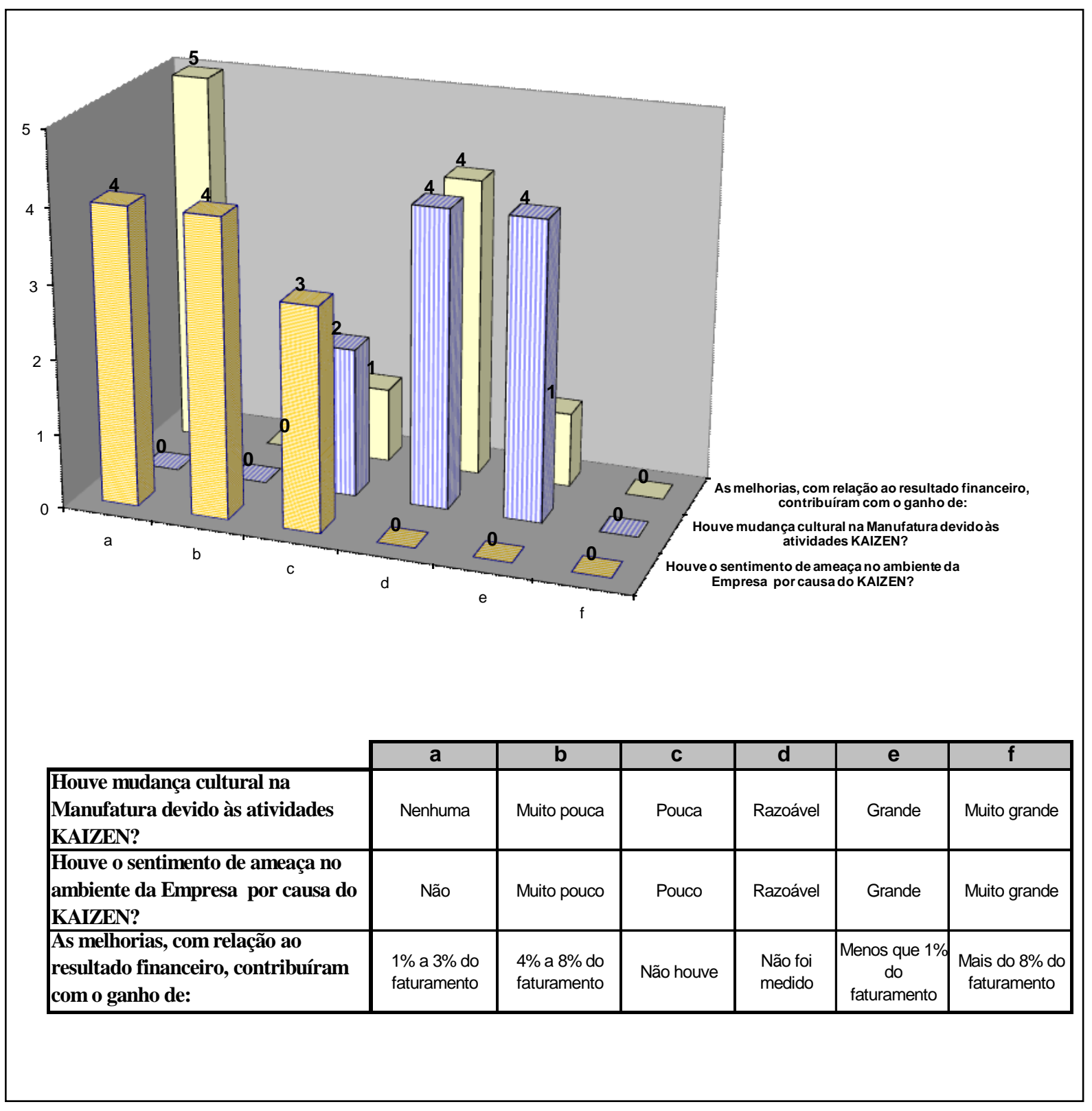

Figura 50 - Comparação de resultados relacionados à mudança cultural e sentimentos de ameaça devido as atividades KAIZEN.

Uma das possíveis razões para que o programa de implantação da metodologia tenha efeito, seria a existência de um ambiente com poucas barreiras às iniciativas de melhoria, pois estas iniciativas exigem mudanças e estas, como já discutido, muitas vezes encontram barreiras. Pelo que foi observado, quando as empresas participantes desta pesquisa foram questionadas a respeito deste tema, mostraram que há poucas barreiras às iniciativas. Este fator aliado a um ambiente aberto, como foi demonstrado pelos resultados relativos ao aspecto da abertura da Manufatura às mudanças, $45 \%$ identificam poucas ou barreiras muito pequenas às iniciativas de 
melhoria e isto faz com que haja a condição para o bom desenvolvimento do KAIZEN. As empresas com mais alto desempenho são aquelas com cultura para uma sustentável e pró-ativa melhoria (Achanga; Shehab; Roy e Nelder, 2005). Tanto as respostas para a questão do nível de barreiras às iniciativas de melhoria quanto àquelas relativas à abertura às mudanças, 91\% dos respondentes têm ambiente de razoavelmente a muito abertos às mudanças, direcionam para a afirmação de que estas condições podem favorecer a obtenção dos resultados positivos apresentados (Figura 51).

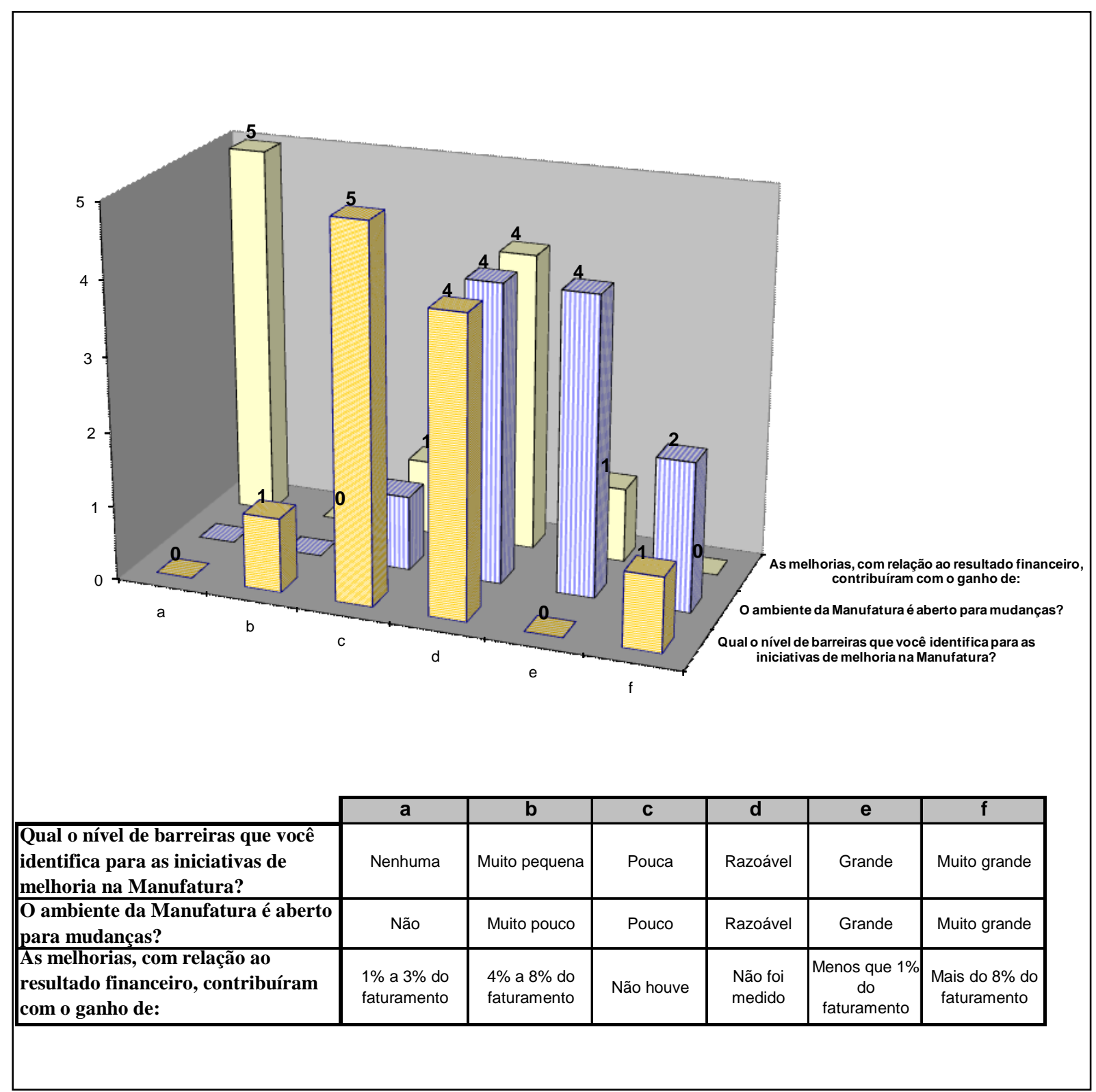

Figura 51 - Comparação de resultados relacionados à nível de barreiras e abertura de ambiente às mudanças

Os resultados às questões sobre a condução da liderança de fábrica nas atividades ou iniciativas de melhoria, $82 \%$ têm uma participação de razoável a 
grande, e a participação efetiva dos operadores nestas atividades, $73 \%$ dos respondentes tem participação grande ou muito grande, levam à afirmação de que estes fatores são importantes para que haja o bom resultado para o programa KAIZEN. Nas empresas participantes da pesquisa encontramos, na maioria delas, uma efetiva participação dos Operadores nas atividades de melhoria e estas são conduzidas pelos Líderes no chão de fábrica (Figura 52). Estas condições são consideradas como importantes para o sucesso do KAIZEN (Imai, 1992) e estão presentes nas empresas pesquisadas, contribuindo para a efetivação dos bons resultados relatados.

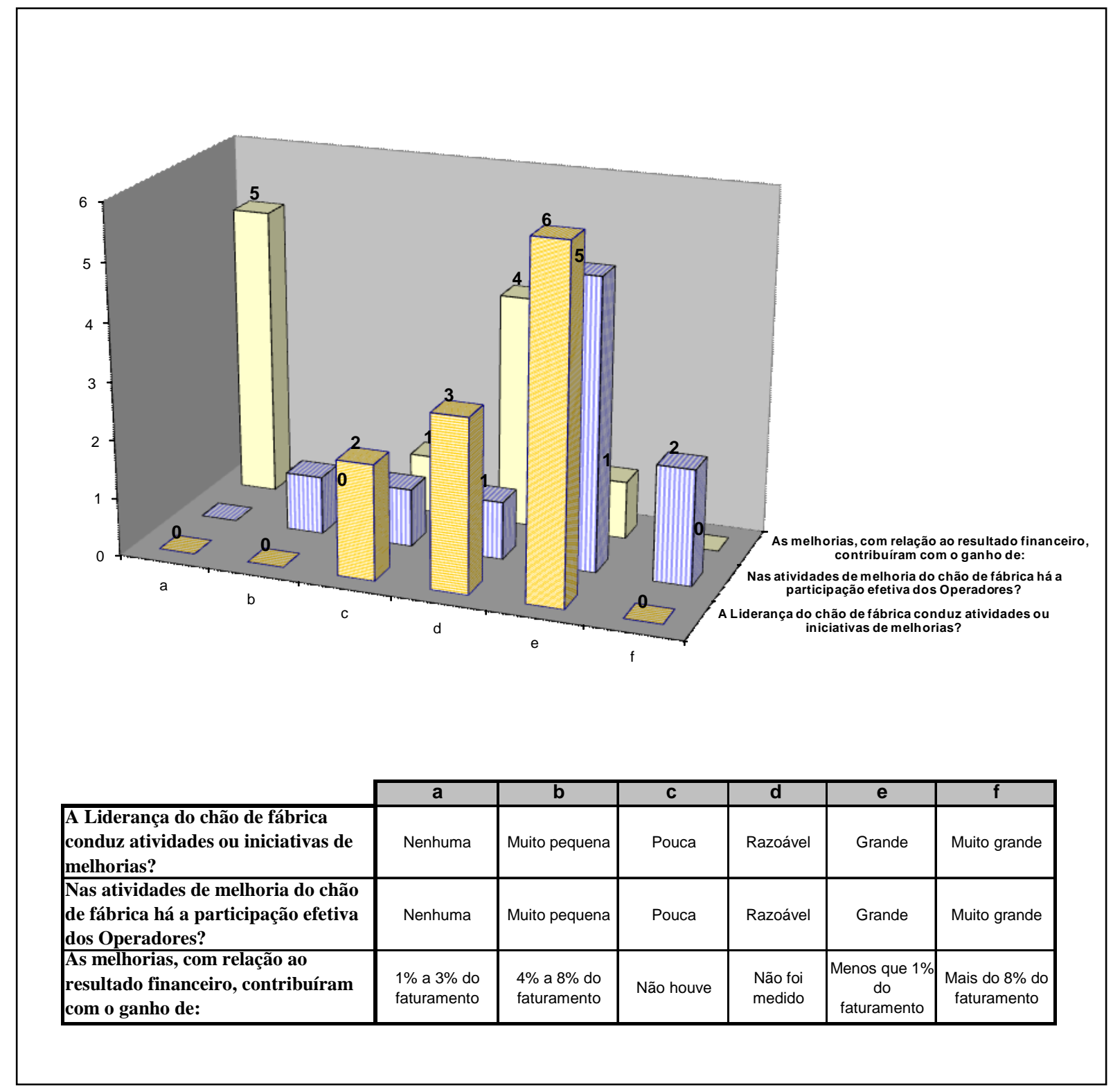

Figura 52 - Comparação de resultados relacionados a condução de atividades de melhoria pela Liderança do chão de fábrica e respectiva participação dos 
Em ambiente aberto e sem barreiras aumenta a oportunidade de participação dos Operadores nas atividades KAIZEN, no programa de sugestões e nos grupos de trabalho para desdobramento e tomadas de decisão. Como mencionado por Imai (1992), as melhorias advindas desta participação contribuem em muito para se alcançar as metas do programa e foi observado que existem estas atividades nas empresas que atingiram os melhores resultados em seus programas KAIZEN.

Nas empresas respondentes, há $82 \%$ que têm participação do pessoal de razoável a muito grande nos programas de sugestão de melhorias, $73 \%$ com participação dos operadores nos projetos KAIZEN de razoável a muito grande, 82\% com participação dos operadores de razoável a grande nos grupos multifuncionais (Figura 53).

Um fator a ser, também, considerado como condição para o sucesso de um programa KAIZEN é o conhecimento básico dos conceitos de eliminação de perdas por parte dos operadores, visto que 64\% das empresas respondentes tem seus operadores com conhecimento de razoável a muito grande nestes conceitos, pois com estes conceitos bem consolidados a participação do pessoal é mais bem direcionada (Figura 54).

Outras prováveis condições para se conseguir os resultados positivos obtidos com o programa KAIZEN seriam:

- Não houve evidência de que um envolvimento de Consultoria para implementação do KAIZEN aumenta as chances de sucesso deste programa, como verificado com as respostas, pois apenas uma das empresas respondentes teve condução dos trabalhos através de uma Consultoria.

- Organizar as atividades KAIZEN de forma estruturada, de certa forma, contribui para o programa KAIZEN, em apenas duas das empresas do levantamento estas atividades têm pouca estruturação e, como vimos resultados econômicos expressivos foram obtidos por várias das 11 empresas pesquisadas. 


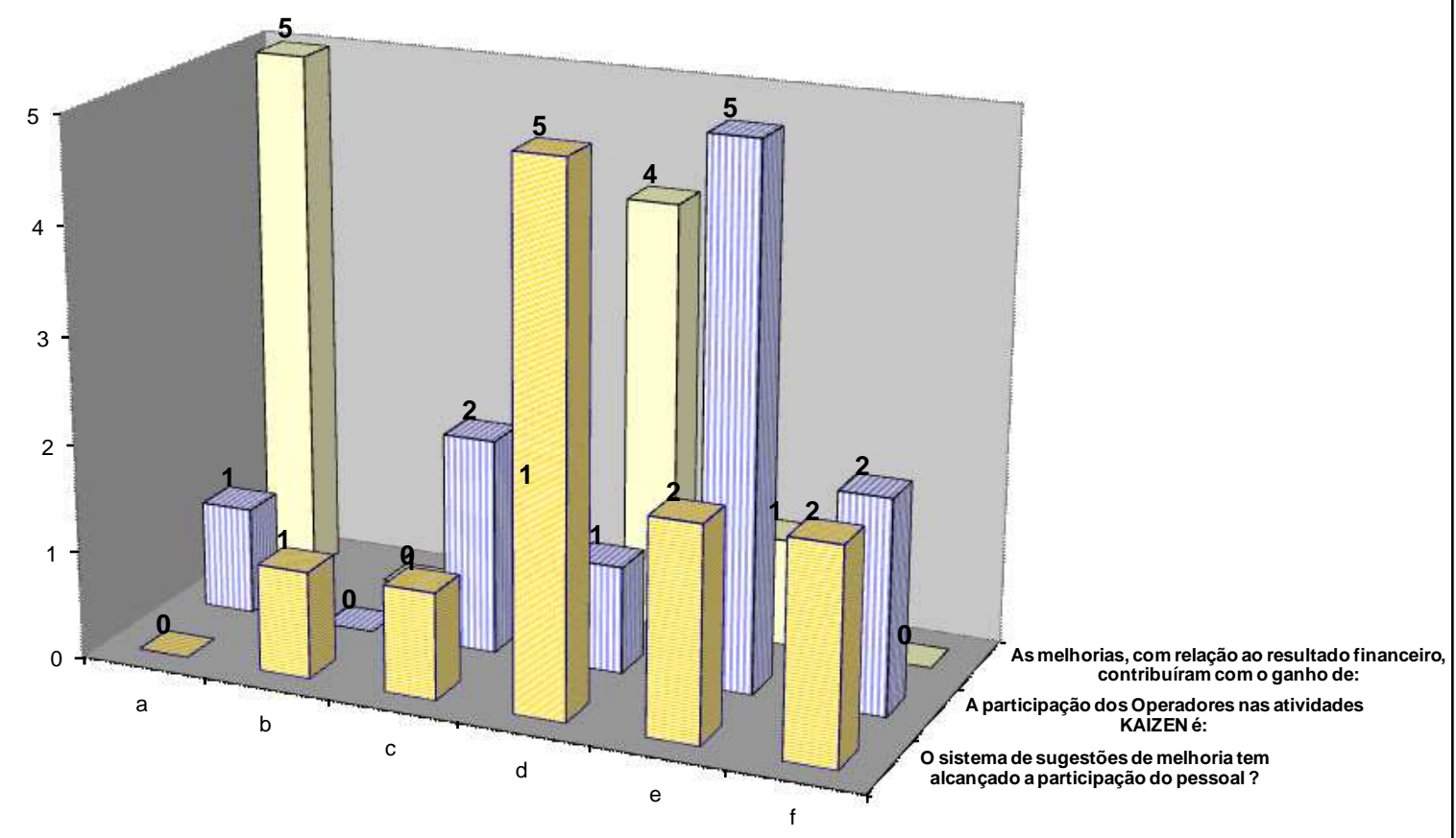

\begin{tabular}{|l|c|c|c|c|c|c|}
\cline { 2 - 6 } & a & b & C & d & e & f \\
\hline $\begin{array}{l}\text { O sistema de sugestões de melhoria } \\
\text { tem alcançado a participação do } \\
\text { pessoal ? }\end{array}$ & Não & Muito pouca & Pouca & Razoável & Grande & Muito grande \\
\hline $\begin{array}{l}\text { A participação dos Operadores nas } \\
\text { atividades KAIZEN é: }\end{array}$ & Nenhuma & Muito pequena & Pouca & Razoável & Grande & Muito grande \\
\hline $\begin{array}{l}\text { As melhorias, com relação ao } \\
\text { resultado financeiro, contribuíram } \\
\text { com o ganho de: }\end{array}$ & $\begin{array}{l}1 \% \text { a 3\% do } \\
\text { faturamento }\end{array}$ & $\begin{array}{l}4 \% \text { a } 8 \% \text { do } \\
\text { faturamento }\end{array}$ & Não houve & $\begin{array}{c}\text { Não foi } \\
\text { medido }\end{array}$ & $\begin{array}{c}\text { Menos que } 1 \% \\
\text { do } \\
\text { faturamento }\end{array}$ & $\begin{array}{c}\text { Mais do } 8 \% \text { do } \\
\text { faturamento }\end{array}$ \\
\hline
\end{tabular}

Figura 53 - Comparação de resultados relacionados a participação do pessoal no programa de sugestões e participação dos operadores no programa KAIZEN.

- A participação da área de recursos humanos é muito importante para o KAIZEN e as respostas recebidas à questão relativa a este assunto reforçam esta idéia pois, das 11 empresas participantes em 8 esta participação está bem presente, significando uma relação possível entre a presença ativa da área de recursos humanos e o sucesso do programa KAIZEN.

- Outro importante fator citado para se alcançar sucesso nos trabalhos do KAIZEN é a participação da alta gerência nas atividades, como afirmado por $55 \%$ dos respondentes, participação também mencionada por Imai(1992) 
como essencial. Isto tem o aspecto de reforçar a importância que a empresa dá ao programa através da figura de seu maior representante, em sua presença ativa em algumas das atividades do KAIZEN (Figura 55).

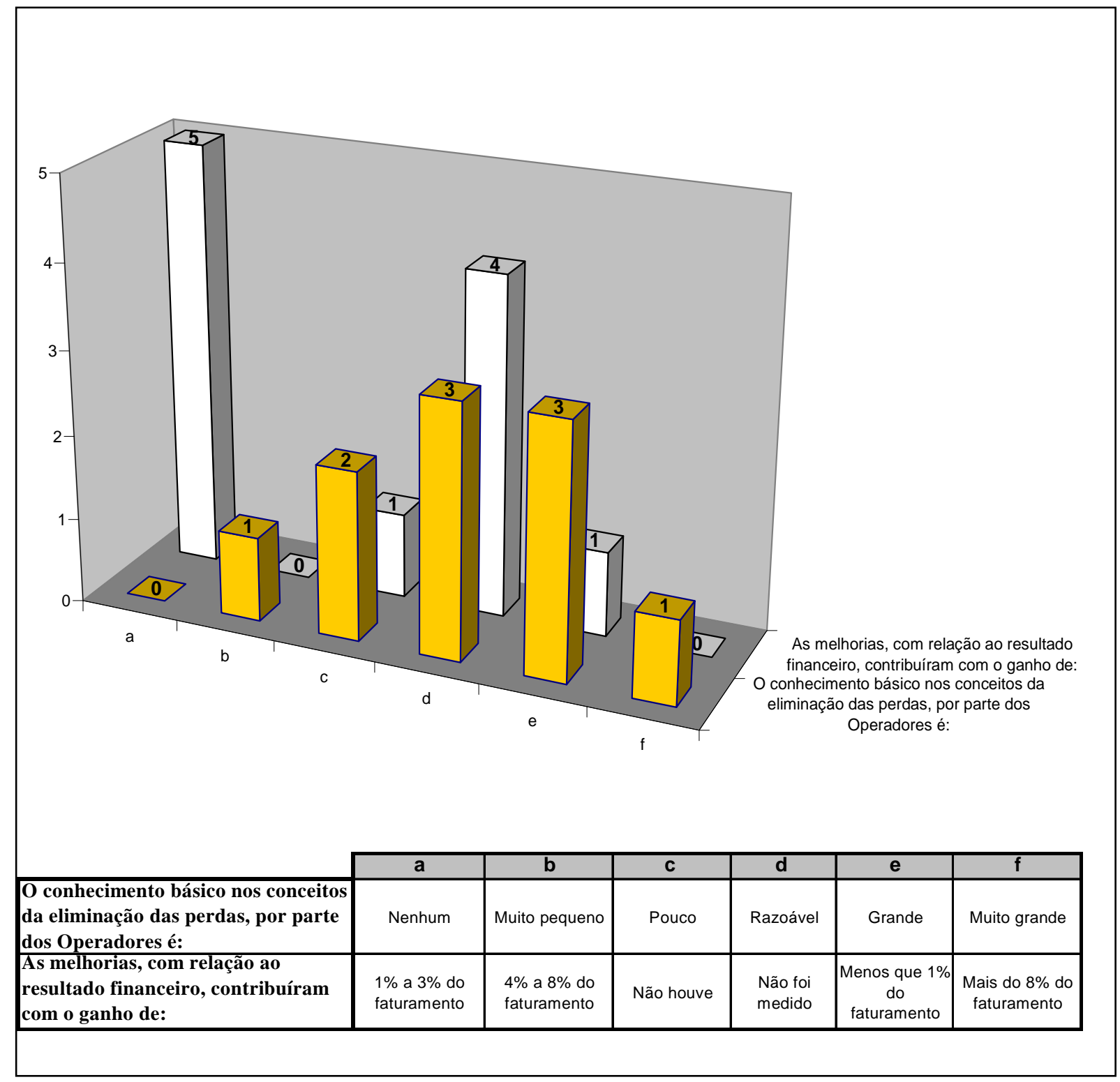

Figura 54 - Comparação de resultados relacionados ao conhecimento de eliminação de perdas por parte dos Operadores. 


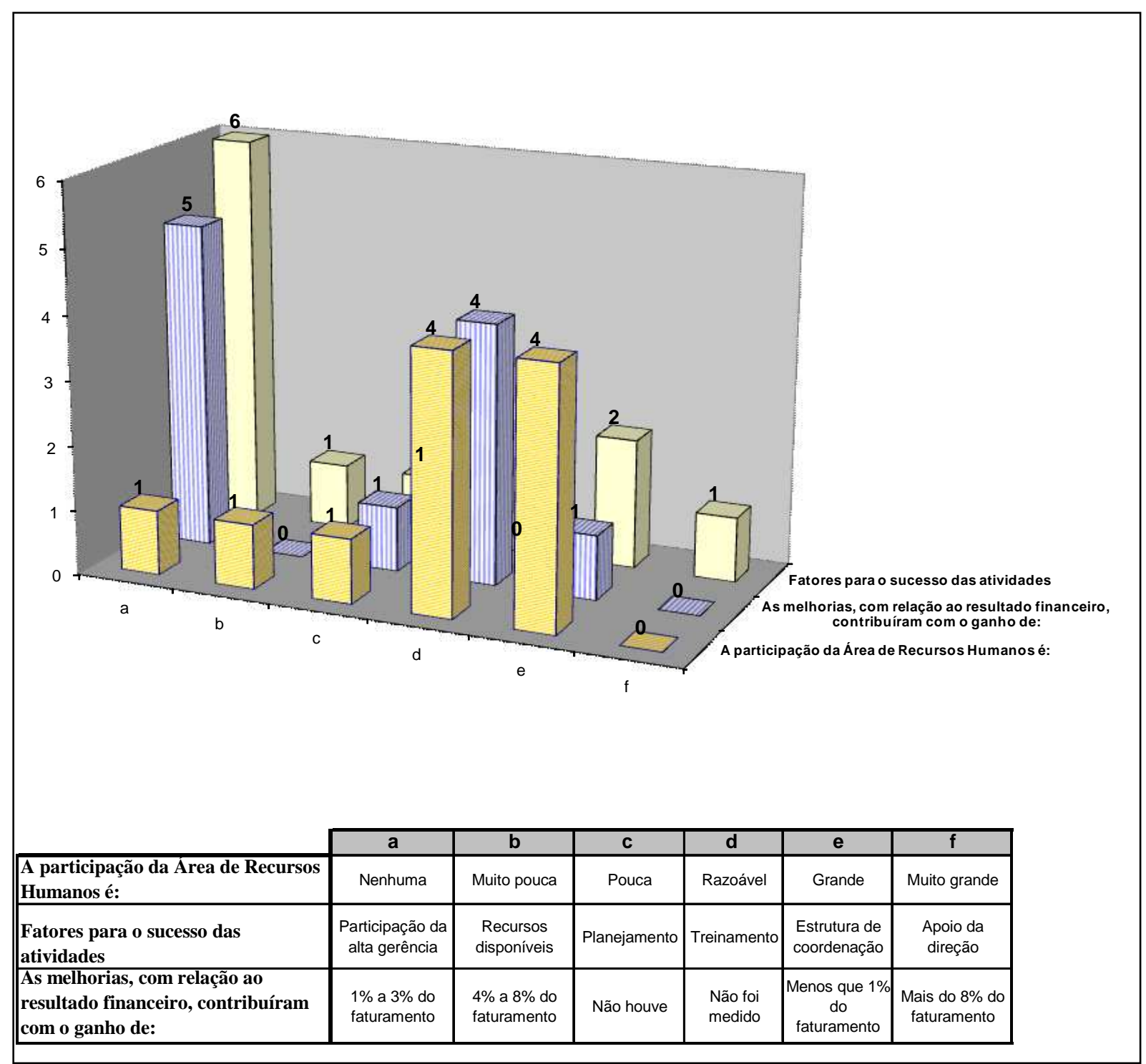

Figura 55 - Comparação de resultados relacionados a participação da Área de Recursos Humanos e fatores de sucesso das atividades do KAIZEN.

Uma avaliação importante é a análise dos pontos em comum entre as cinco empresas cujos respondentes afirmaram terem tido ganhos entre $1 \%$ e $3 \%$ de seus faturamentos, utilizando a metodologia KAIZEN. Através da figura 56 pode-se observar, entre algumas das questões importantes relacionadas ao tema, que:

- A maioria tem grandes barreiras para iniciativas de melhoria, três respostas. Isto pode significar que, mesmo tendo resultados positivos com a metodologia, estas empresas encontraram dificuldades para sua implementação. 


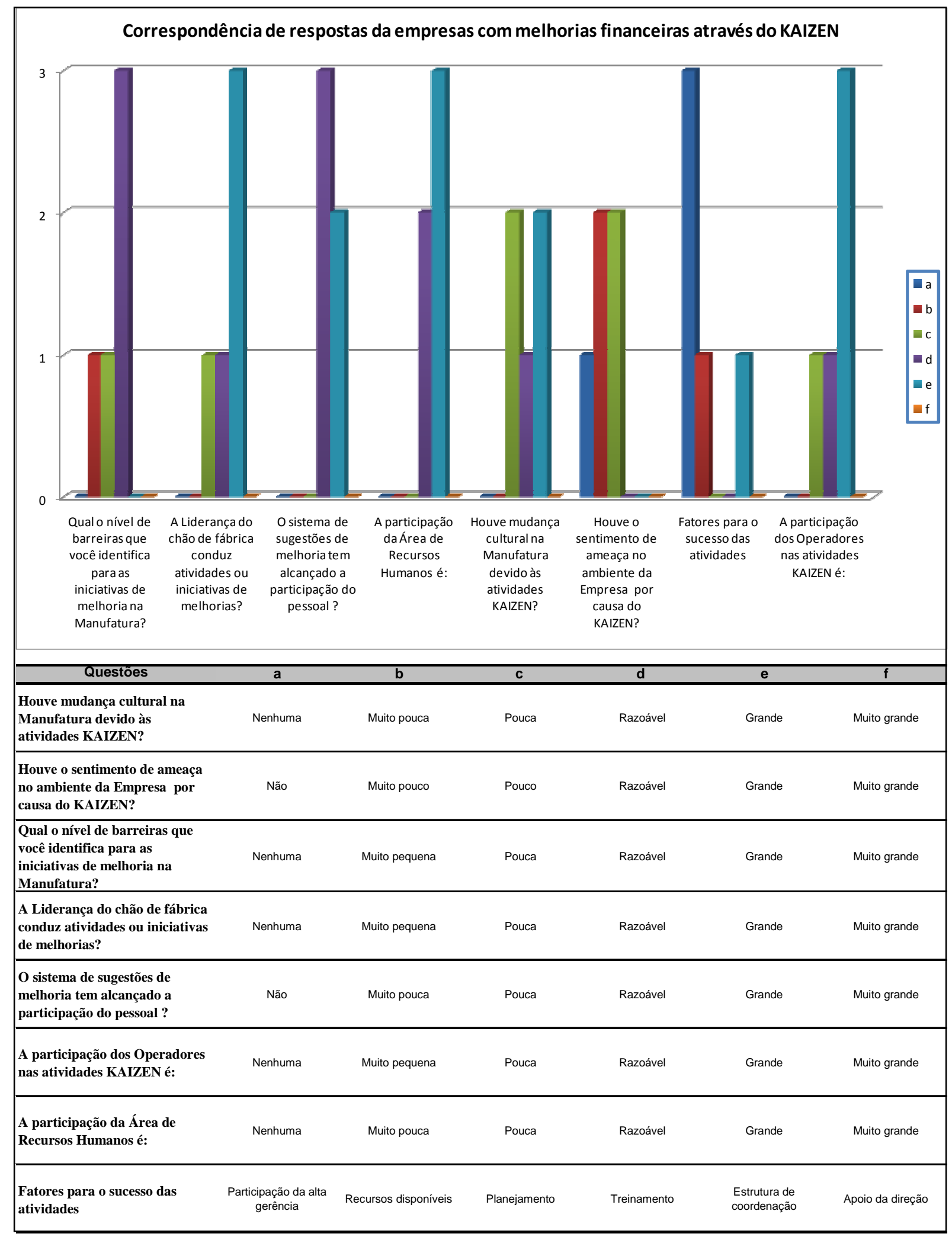

Figura 56 - Comparação entre respostas de empresas que obtiveram ganhos entre $1 \%$ e $3 \%$ sobre seus faturamentos. 
- A Liderança do chão de fábrica conduz as atividades de melhoria, pois temos uma resposta para uma condução que acontece de forma razoável e três respostas afirmando que esta condução é grande.

- No sistema de sugestões de melhoria há uma importante participação do pessoal, entre estas empresas, visto que acontece de forma razoável a grande.

- Acontece a participação da área de recursos humanos de forma razoável a grande.

- Não se pode afirmar que entre estas empresas a mudança cultural seja um ponto em comum, pois duas delas houve pouca mudança, uma com razoável e outras duas com grande mudança. Pressupõe-se que, entre as empresas cujas respostas indicam que houve pouca mudança, estas já teriam uma cultura direcionada à melhoria contínua.

- O sentimento de ameaça devido à implementação da metodologia KAIZEN não foi um ponto que preocupou seus condutores. De acordo com as respostas desta empresas, no máximo este sentimento foi pequeno, quando não muito pequeno ou nulo.

- A maioria destas empresas considera a participação da alta gerência o principal fator para o sucesso das atividades KAIZEN.

- A participação dos operadores nas atividades KAIZEN acontece em sua maioria de forma grande. Inesperadamente há uma resposta indicando pouca participação destes operadores, pois conforme Imai (1992) isto é uma das bases da metodologia KAIZEN.

\subsection{Situação da utilização e entendimento da metodologia KAIZEN nas empresas}

Além da discussão sobre os resultados da implementação do KAIZEN nas empresas fabricantes de autopeças, foram propostas as discussões a respeito das questões abaixo:

- Como está a utilização da metodologia KAIZEN? 
- Qual é o entendimento que se tem do tema KAIZEN?

Para realizar a discussão proposta analisaremos as questões que poderiam dar uma visão daquilo que se está fazendo a respeito do KAIZEN e demonstrando o entendimento que estas empresas têm deste tema.

Inicialmente, comentando o quanto o conceito de valor agregado e valor não agregado estão estabelecidos nas empresas, observa-se que estes conceitos existem e são bem compreendidos pelo pessoal, pois no mínimo se tem um entendimento razoável, segundo os respondentes. Esta demonstração de conceituação pode redundar em melhores análises para compreensão da correta posição dos pontos de oportunidade de melhoria e pontos de apoio para os trabalhos do KAIZEN. Com base no bom entendimento destes conceitos é de se entender que o nível de barreiras identificado para as iniciativas de melhoria na manufatura seja pequeno, $55 \%$ responderam que as barreiras são pequenas ou muito pequenas. Podendo contribuir para que o pessoal tenha a base necessária nas práticas destinadas à melhoria e para o conhecimento básico nos conceitos de eliminação de perdas por parte dos operadores, $64 \%$ com conhecimento de razoável a muito grande. A política de desenvolvimento de pessoal é colocada de forma bem estabelecida de acordo com as respostas ao questionário, 91\% com políticas de razoável a muito grande, assim como os critérios de competência, conhecimento e habilidades estão definidos para os cargos do chão de fábrica, segundo a maior parte das empresas respondentes, em $91 \%$ das respostas isto acontece de forma razoável a muito grande.

Ao realizar o mapeamento do fluxo de valor (Value Stream Map) (Rother e Shook, 1996) a empresa tem várias opções de oportunidades para direcionar seus esforços de melhoria. A partir do posicionamento à questão sobre a existência deste mapeamento nas empresas participantes da pesquisa, verifica-se que $100 \%$ delas estão realizando este mapeamento em maior ou menor quantidade entre suas áreas internas, sendo por si só uma forma de iniciativa estruturada de melhoria. Realmente, as empresas consultadas estão realizando estas iniciativas de acordo com as respostas obtidas à questão sobre se a empresa tem realizado iniciativas estruturadas para melhoria de produtividade, visto que $91 \%$ têm iniciativas de forma grande ou muito grande. Como foi verificado, não há um padrão para dizer qual o tamanho do envolvimento de uma consultoria externa na participação nestas iniciativas ou em outros trabalhos voltados ao KAIZEN. Em apenas uma das 
empresas a condução total dos trabalhos do KAIZEN é feito por uma consultoria, mas em todas as empresas há alguma participação destas.

Não há um padrão entre as empresas pesquisadas para, ao realizarem seus projetos de melhoria, estender este processo às suas respectivas cadeias de fornecimento pelo que foi observado nas respostas recebidas, visto que $45 \%$ apenas têm grande iniciativas neste sentido.

Nas empresas participantes da pesquisa, há bastante consideração em relação à redução de estoques, pois $100 \%$ das empresas respondentes tem consideração de razoável a muito grande e a introdução de novas tecnologias leva em consideração a redução de perdas na Manufatura, apenas uma das empresas participantes diz não considerar este fator.

Um dos importantes aspectos relacionados a um programa como o a da implementação e consolidação da metodologia KAIZEN é a participação da liderança (Imai, 1992) e nas empresas representadas aqui, a liderança no chão de fábrica tem importante papel na condução das atividades ou iniciativas de melhoria, em 82 \% das empresas respondentes ela faz esta condução. Observa-se na maioria das empresas pesquisadas, flexibilidade e adaptabilidade para lidar com as exigências criadas pelas variações de demanda, pois 82 \% têm isto acontecendo de forma razoável a muito grande. Isto pode ser o resultado de uma gestão da manufatura onde os diversos ambientes resultantes dos processos de mudança são enfrentados e os padrões estabelecidos por muitos anos, na mentalidade voltada á produção em massa, são modificados, visto que em 54\% das respondentes a gestão da manufatura contempla os diversos ambientes resultantes dos processos de mudança de forma razoável a muito grande. Ressalta-se que estas atividades de melhoria têm continuidade, menção feita pela maioria das empresas respondentes, onde verifica-se $73 \%$ com continuidade de razoável a muito grande.

O principal fator de motivação para o início dos programas KAIZEN nas empresas pesquisadas foi o de eliminar as perdas para o desenvolvimento da manufatura "enxuta", 82\% das respostas, e as iniciativas partiram, em sua maioria, da alta direção e média gerência das empresas, divulgando os conceitos do KAIZEN para toda a empresa, $45 \%$ das respostas.

Não há entre as empresas que participaram desta pesquisa, alguma ferramenta do KAIZEN que tenha destaque. Entre as ferramentas de redução de tempo de troca de ferramentas (SMED), manutenção produtiva total (TPM), mapeamento da 
qualidade, mapeamento do fluxo de processo, criação de operações padrão, obtevese a maioria das respostas para a opção em que as empresas afirmam que aplicam todas as ferramentas na mesma intensidade, 27\%. Com a contabilização dos ganhos sendo executada, na maioria das empresas respondentes, através de pessoal específico para este fim, 36\% das respostas.

Finalmente, as respostas dizem que existe certa dificuldade para manutenção dos ganhos do KAIZEN, apenas 36\% dizem não haver ou que há pouca dificuldade em se manter os ganhos, e não há um cuidado principal para sustentar o programa KAIZEN, de acordo com as respostas obtidas talvez seja necessário um pouco de cada cuidado citado: criar procedimentos referentes às ações implementadas, fazer verificações periódicas, envolvimento contínuo do pessoal de chão de fábrica e o monitoramento da alta direção. 


\section{CONCLUSÃO}

Este trabalho foi preparado com a finalidade de responder a questão sobre quanto a metodologia KAIZEN influencia nos resultados das empresas fabricantes de autopeças do Brasil. Através de um levantamento amostral foi criada a oportunidade de, além de obter a resposta à questão proposta, se conhecer um pouco da situação das empresas em relação a como estão posicionados seus programas de utilização da metodologia.

O levantamento amostral foi direcionado ao ambiente das empresas fabricantes de autopeças que utilizam a metodologia KAIZEN e os resultados foram bastante satisfatórios porque a questão principal da pesquisa foi respondida como se planejara inicialmente. Dentro da amostragem foi claramente observável que a aplicação da metodologia KAIZEN nas empresas produz resultados financeiros positivos diretos, além de resultados indiretos, principalmente aqueles relacionados à melhoria da motivação e participação do pessoal, conforme se pode verificar através da análise dos resultados. Além do mais, foram constatadas que existem condições nas empresas que proporcionam o sucesso da implementação, dentre várias, aquelas ligadas à participação da liderança de fábrica e apoio da alta gerência. Este seria um direcionamento para outras empresas quando se propuserem a seguir os caminhos do KAIZEN.

Como a credibilidade da amostragem foi analisada e confirmada na seção 5.6, pode-se propor que os resultados obtidos sejam extensíveis à população dos fabricantes de autopeças que aplicam a metodologia KAIZEN, mas não se pode generalizar estes resultados a todas as empresas que empreguem ou venham a empregar esta metodologia. Não foi conseguido, através deste trabalho, um embasamento estatístico que proporcionasse esta posição. No entanto, cabe afirmar que, intuitivamente, isto pode acontecer e para confirmação desta possibilidade novas pesquisas podem ser executadas em trabalhos futuros.

Cabe o comentário adicional, feito a partir de observações realizadas nos ambientes fabris das empresas participantes da pesquisa, que estas empresas 
pertencem, apesar da diversidade dos seus tamanhos, a uma classe de empresas que está em um nível de organização, tanto técnico como em gerenciamento de recursos humanos, superior em relação ao universo de empresas que atuam no Brasil, por esta razão este nível de organização possa ser um pré-requisito para implementação do KAIZEN.

Algumas novas questões surgiram ao longo do desenvolvimento deste trabalho. Estas seriam:

- Quanto tempo é necessário para consolidação do trabalho de completa implementação do KAIZEN e este passar a ser algo habitual dentro do ambiente da empresa?

- Em algum momento as atividades KAIZEN podem ficar desacreditadas se não houver um correto direcionamento àqueles "elos" mais fracos da empresa?

- A metodologia KAIZEN pode ser aplicada a qualquer tipo de ramo empresarial?

Novamente, para generalização dos resultados desta pesquisa seria necessária uma avaliação com embasamento estatístico e, para isto, é preciso que haja uma formatação específica do instrumento de levantamento amostral (questionário), sendo diretamente desenvolvido para este fim.

Em futuros trabalhos é proposto, então, que seja feito o encaminhamento para procurar a confirmação da abrangência dos resultados obtidos a partir de uma população maior de empresas, incluindo, também, as novas questões surgidas no trabalho presente. 


\section{REFERÊNCIAS}

ACHANGA, P., SHEHAB, E., ROY, R., NELDER, G. Critical factors for lean implementation within SMEs. Journal of Manufacturing Technology Management. Cranfield, UK. Vol. 17. No. 4. pp. 460-471. 2006.

AGUIAR, M.A.de S. Manual Básico de Pesquisa de Mercado. Ed. SEBRAE. 111 p. 1998.

ALBRECHT, K., BRADFORD, L.J. Serviços com Qualidade: A vantagem Competitiva. Makron Books. 227 p. São Paulo. 1992.

ALRECK, P.L., SETTLE, R.B. The survey research handbook. Irwin. Homewood, IL. 1985.

AMUNDSON, S.D. Relationship between theory-driven empirical research in operations management and other disciplines. Journal of Operations Management. Vol. 16 No. 4. pp. 341-359. 1998

ANDERSON et al. A theory of quality management underlying the Deming management method. Academy of Management Review. Vol. 19 No. 3. pp. 472509. 1994

BABBIE, E. Survey Research Methods. Wadsworth. Belmont, CA. 1990

BAMBER, C.J.et al. Cross Functional team working for overall equipment effectiveness (OEE). Journal of Quality in Maintenance Engineering. Vol. 9 No. 3. pp. 223-238. 2003

BHASIN, S., BURCHER, P. Lean viewed as a philosophy. Journal of Manufacturing Technology. Birmingham, UK. Vol. 17, No. 1. pp. 56-72. 2006.

BIRNBAUM, M.H. Testing critical properties of decision making on the Internet. American Psychological Society. Vol. 10 No. 5. pp. 399-407. 1999. 
BRUNET, A.P.; NEW, S. KAIZEN in Japan: an empirical study. International Journal of Operations \& Production Management. Oxford. Vol. 23. n. 12. p. 14261446. 2003

CAMINADA NETTO, A. Gestão da Qualidade em projeto de desenvolvimento do produto: contribuição para avaliação da eficácia. 2006. $319 \mathrm{p}$. Tese (doutorado) - Escola Politécnica da Universidade de São Paulo. São Paulo.

CLIFFORD, G.P., SOHAL, A.S. Developing self-directed work teams. Management Decision. Melbourn. Vol. 36 No. 2. pp. 77-84. 1998.

COFFEY, D., THORNLEY, C. Automation, motivation and lean production reconsidered. Assembly Automotion. Leeds, UK. Vol. 26 No. 2. pp. 98-103. 2006

COLLINS, R.S.; BECHLER, K.; PIRES, S.R.I. Outsourcing in the Automotive Industry: From JIT to Modular Consortia. European Management Journal. Vol. 15 No. 5. pp.498-508. 1997

COMM, C.,L., MATHAISEL, D.F.X. A paradigm benchmarking lean initiatives for quality improvement, Benchmarking. International Journal. Vol. 7 No. 2. pp. 118-127. 2000

CONVERSE, J.M., PRESSER, S. Survey questions. Handcrafting the standardized questionnaire. Sage. New York, NY. 1988.

DANE, F.C. Research methods. Belmont. Brooks/Cole. 1990

DANSEREAU, F., MARKHAM, S.E. Level of analysis in personnel and human resources management. Vol. 5. JAI Press. Greenwich, CT. 1997.

DEMING, W.E. Out of the Crises. Cambridge, Mass. Massachusetts Institute of Technology. Center for Advanced Engineering Study. 507p. 1986.

DILLMAN, D.A. Mail and telephone survey: the design method. John Wiley \& Sons. New York, NY. 1978.

DUBIN, R. Theory building. The Free Press. New York, NY. 1978. 
ELGAR, T. ; SMITH, C. Global Japanization: The Transnational Transformation of the Labour Process. Routledge, London. 1994.

EMILIANI, M.L. Supporting small business in their transition to lean production. Journal of Manufacturing Technology Management. Vol. 15 No. 7. 2004.

EMORY, C.W., COOPER, D.R. Business research methods. Irwin. Homewood, IL. 1991.

FILIPPINI. Operation management research: some reflections on evolution models and empirical studies in OM. International Journal of Operations \& Production Management. Vol. 17 No. 7. pp. 675-670. 1997.

FLYNN et al. Empirical research methods in operations management. Journal of Operations Management. Vol. 9 No. 2. pp. 250-84. 1990

FORRESTER, R. Implications of lean manufacturing for human resource strategy. Work Study. Vol. 44 No. 2. Edinburgh, UK. pp. 20-24. 1995.

FORZA, C. Quality information systems and quality management: a reference model and associated measures for empirical research. Industrial Management and Data Systems. Vol. 95 No. 2. pp. 6-14. 1995

FORZA, C., DI NUZZO, F. Meta-analyses applied to operations management: summarizing the results of empirical research. International Journal of Production Research. Vol. 36 No. 3. pp. 837-861. 1998.

FORZA, V. Survey Research in operations management: a process-based perspective. International Journal of Operations \& Production Management. Vol. 22 no. 2. pp. 152-194. Vicenca, It. 2002

GONDHALEKAR, S., KARAMCHANDANI, V. Robust KAIZENs Systems. The TQM Magazine. Vol. 6 No. 3. pp. 5-8. 1994.

HAAN et al. Production planning in Japan: rediscovering lost experiences or new insights? International Journal of Production Economics. Vol.71. pp. 101-9. 2001 
HALL, R. Zero Inventories. Dow-Jones Irwin. Homewood, IL. 1983

HANDFIELD, R.B., MELNYK, S.A. The scientific theory-building process: a primer using the case of TQM. Journal of Operations Management. Vol. 16 No. 4. pp. 321-339. 1998.

HENSLEY, R.L. A review of operations management studies using scale development techniques. Journal of Management. Vol. 17 No. 2. pp343-358. 1999.

HILL, M.M., HILL, A. A construção de um questionário. Dinâmia. 54p. Lisboa. 1998.

HINES, P.; RICH, N. The seven value stream mapping tools. International Journal of Operations \& Production Management. Vol. 17 No. 1. pp. 46-64. 1997.

HINKIN, T.R. A review of scale development practices in the study of organizations. Journal of Management. Vol. 21 No. 5. pp. 967-988. 1995.

HIROMOTO, T. Another hidden edge - Japanese Management accounting. Harvard Business Review. Boston, MA. pp. 22-26. 1988.

HOLWEG, M.; PIL, F. Successful build-to-order strategies start with the customer. Sloan Management Review. Vol. 43 No. 1. pp. 74-83. 2001.

IMAI, M. KAIZEN: a chave do sucesso competitivo japonês. São Paulo. IMAM. 1992.

KAPLAN, R.S.; NORTON, D.P. Using a balanced scorecard as a strategic management system. Harvard Business Review. Vol. 74 No. 1. pp. 74-85.

KERLINGER, F.N. Foundations of behavioral Research. 3a. Ed., Harcourt Brace Jovanovich College Publishers. New York, NY. 1986.

KUMAR, S., HARMS, R. Improving business processes for increased operational efficiency: a case study. Journal of Manufacturing Technology Management. Vol. 15 No. 7. pp. 662-674. 2004. 
LAUGEN, B.T., BOER, H., ACUR, N., FRICK, J. Best manufacturing practices, what do the best-performing companies do? International Journal of Operations and Production Management. Vol. 25 No. 2. pp. 131-150. 2005.

LAZARSFELD, P.F. The art of asking why. National Marketing Research. Vol. 1. pp. 26-38. 1935.

LEWIS, M.A. Lean production and sustainable competitive advantage. International Journal of Operations and Production Management. Vol. 20, No. 8. pp. 959-978. 2000.

LILRANK, P.; KANO, N. Continuous Improvement: Quality Circles in Japanese Industry. Center for Japanese Studies. Michigan, Ann Arbor. 1989

LYNCH, R.F and WERNER, T.J. A league of their own. Small Business Reports. Vol. 19

No. 4. pp. 35-42. 1994.

MALHOTRA, N..K., GROVER, V. An assessment of survey research in POM: from construct to theory. Journal of Operations Management. Vol. 16 No. 17. pp. 26-38. 1998.

MALHOTRA, N.K. Pesquisa de Marketing - uma orientação aplicada. 3a ed. Porto Alegre. Bookman. 2001.

MASLOW, A.H. Introdução à psicologia do ser. 2 ed. Rio de Janeiro: Eldorado. 279 p. 1970.

MAYO, E. Problemas humanos de una civilización industrial. Buenos Aires: Galatea. Nueva Visión. 171p. 1959.

MEREDITH, T.R.et al. Alternative research paradigms in operations. Journal of Operations Management. Vol. 8 No. 4. pp. 297-326. 1989.

MIYAI, J. The redesign of Japanese management systems and practices. APO Productivity Journal. Summer. pp. 2-11. 1995. 
MODEN, Y. Toyota Production System. Industrial Engineering and Management Press. pp.137-154. Norcross, GA. 1983.

MOTWANI, J. A business process change framework for examining lean manufacturing: a case study. Industrial Management and Data System. Michigan, USA. Vol. 103 No. 5. pp. 339-346. 2003.

NAKAJIMA, S. La Maintenance Productive Totale (TPM) Mise en Oeuvre. Afnor. Paris. 1989

NONAKA, I.; TAKEUCHI, H. Criação de conhecimento na empresa. 8 ed. Rio de Janeiro. Campus. 1997.

OHNO, T. Sistema de produção Toyota. Porto Alegre: Bookman. 1988.

PARKINSON, C. N. Parkinson's Law. The Economist. London. November Edition. 1955.

PATEL, S., DALE, B.G., SHAW, P. Set-up reduction and mistake proofing methods: an examination in precision component manufacturing. The TQM Magazine. Manchester, UK. Vol. 13 No. 3. pp. 175-179. 2001.

PINSONNEAULT, A.,KRAEMER, K.L. Survey research methodology in management information systems: an assessment. Journal of Management Information Systems. Vol. 10 No. 2. pp. 75-106. 1993.

REA, L.M.; PARKE, R.A. Designing and conducting survey research. Jossey Bass. San Francisco, CA. 1992.

ROBINSON, W.S. Ecological correlations and the behaviors of individual. American Sociological Review. Vol. 15. 1950.

ROSSI et al. Handbook of Survey Research. Academic Press. New York, NY. 1983.

ROTHER, M.; SHOCK, J. Aprendendo a enxergar: mapeando o fluxo de valor para agregar valor e eliminar desperdícios. Tradução de José Roberto Ferro e Telma Rodriguez. São Paulo. Lean Institute Brasil. 1996. 
RUNGTUSANATHAM, M.J. et al. Survey research in production/operations management: historical analysis and opportunities for improvement. Working Paper of Department of Management. Arizona State University. Tampa, AZ. 2001.

RUNGTUSANATHAM, M.J. Let's not overlook content validity. Decision Line. pp. 10-13. 1998.

SANDRAS, W.A. Just-in-Time: Making it Happen. Unleashing the Power of Continuous Improvement. John Wiley \& Sons. New York, NY. 1989

SCHONBERGER, R. World Class Manufacturing. Free Press. New York, NY. 1996.

SCUDDER, G.D.; HILL, C.A. A review and classification of empirical research in operations management. Journal of Operations Management. Vol. 16 No. 1. pp. 91-101. 1998.

SEKARAN, U. Research methods for business. John Wiley \& Sons, New York, NY. 1992

SELLITTO, C. Improving winery survey response rates: lessons from the Australian wine industry. International Journal of Marketing. Vol. 18, No. 2. pp. 150-152. 2006.

SENGE. The Fifth Discipline. Doubleday. New York. 1990.

SERVIÇO BRASILEIRO DE APOIO ÀS MICRO E PEQUENAS EMPRESAS SEBRAE. Critérios e conceitos para classificação de empresas. Disponível em: http://www.sebrae.com.br/customizado/estudos-e-pesquisas/bia-97-criterios-paraclassificacao-do-porte-de-empresas/BIA 97/integra bia. Acesso em 06 de Ago. 2008.

SHINGO, S. O sistema Toyota de produção: do ponto de vista da engenharia de produção. Tradução de Eduardo Schaan. Porto Alegre. Bookman. 1996.

SIEKMAN, P. Cessna tackles lean manufacturing. Fortune. Vol. 141. pp. 222231. 2000. 
SINDICATO NACIONAL DA INDÚSTRIA DE COMPONENTES PARA VEÍCULOS AUTOMOTORES - SINDIPEÇAS. Desempenho do Setor de Autopeças. São Paulo, SP. 2006.

SOHAL, A. Developing a lean production organization: an Australian case study. International Journal of Operations and Production Management. Vol.16 No. 2. pp. 91-102. 1996.

SOMMERVILLE, A.K. Changing culture, Quality Assurance in Education. Edinburgh. Vol. 4 No 1. pp. 32-36. 1996.

SUDMAN, S. Applied sampling, in Rossi, P.H., Wright, J.D., ANDERSON, A.B. Handbook of survey research. Academic Press. New York, NY. pp. 144-194. 1983.

SUMANTH, D.J. Productivity Engineering and Management: Productivity Measurement. Evaluation, Planning, and Improvement in Manufacturing and Service Organizations. New York: McGraw-Hill Companies. 547 p. 1984.

TSUTSUI, W.M. Manufacturing Ideology: Scientific Management in Twentieth Century. Japan. Princeton University Press. Princeton, NJ. 1998.

UTTERBACK, J. Mastering the Dynamics of Innovation. Harvard Business School Press. Boston. 1995.

WACKER, J.G. A definition of theory: research guidelines for different theorybuilding research methods in operations management. Journal of Operations Management. Vo. 16 No. 4. pp. 361-385. 1998.

WOMACK, J.P. et al. A máquina que mudou o mundo. 2.Ed. Rio de Janeiro. Campus. 1992

WOMACK, J.P.; JONES, D.T. A mentalidade enxuta nas empresas: elimine o desperdício e crie riqueza. Tradução de Ana Beatriz Rodrigues e Priscila Martins Celeste. Rio de Janeiro: Campus. 1996. 


\section{Anexo A}

\section{Levantamento Amostral}

Tabulação de Respostas

\begin{tabular}{|c|c|c|c|c|c|c|c|c|c|c|c|c|}
\hline \multirow{2}{*}{ Bloco } & \multirow[b]{2}{*}{ Questão } & \multicolumn{11}{|c|}{ Empresa } \\
\hline & & $\bar{A}$ & $B$ & $\mathrm{C}$ & $\bar{D}$ & $E$ & $\mathrm{~F}$ & $G$ & $\mathrm{H}$ & $\mathrm{I}$ & $J$ & $\mathrm{~L}$ \\
\hline \multirow{9}{*}{ B } & \begin{tabular}{|r|}
1 \\
\end{tabular} & $\mathrm{e}$ & $\mathrm{e}$ & $d$ & $d$ & $d$ & $d$ & $\mathrm{e}$ & $f$ & $d$ & $\mathrm{e}$ & $\mathrm{d}$ \\
\hline & 2 & $f$ & $\mathrm{e}$ & $d$ & $\mathrm{e}$ & $\mathrm{e}$ & $\mathrm{e}$ & $f$ & $f$ & $\mathrm{e}$ & $\mathrm{e}$ & $\mathrm{e}$ \\
\hline & 3 & $b$ & $\mathrm{C}$ & $d$ & $f$ & $d$ & $d$ & $\mathrm{C}$ & C & C & $d$ & $\mathrm{C}$ \\
\hline & 4 & $\mathrm{~d}$ & $\mathrm{C}$ & $b$ & $d$ & $C$ & $d$ & $\mathrm{C}$ & $f$ & $\mathrm{e}$ & $\mathrm{e}$ & $f$ \\
\hline & 5 & $f$ & $\mathrm{e}$ & $d$ & $C$ & $d$ & $d$ & $\mathrm{e}$ & $f$ & $\mathrm{e}$ & $e$ & $\mathrm{~d}$ \\
\hline & 6 & C & $\mathrm{C}$ & $C$ & $d$ & $C$ & $\mathrm{C}$ & $\mathrm{e}$ & $\mathrm{e}$ & $\mathrm{e}$ & $\mathrm{e}$ & $\mathrm{e}$ \\
\hline & 7 & $\mathrm{e}$ & $\mathrm{e}$ & $\mathrm{e}$ & $f$ & $f$ & $\mathrm{e}$ & $f$ & $f$ & $a$ & $\mathrm{e}$ & $\mathrm{d}$ \\
\hline & 8 & $\mathrm{e}$ & $\mathrm{e}$ & $\mathrm{e}$ & $f$ & $f$ & $f$ & $f$ & $f$ & $d$ & $\mathrm{e}$ & $\mathrm{e}$ \\
\hline & 9 & $\mathrm{e}$ & $\mathrm{e}$ & $d$ & $b$ & $d$ & $d$ & $\mathrm{e}$ & $\mathrm{e}$ & $d$ & $\mathrm{e}$ & $f$ \\
\hline \multirow{9}{*}{ C } & 1 & $\mathrm{e}$ & $\mathrm{C}$ & $d$ & $\mathrm{e}$ & $C$ & $d$ & $\mathrm{e}$ & $\mathrm{e}$ & $\mathrm{d}$ & $\mathrm{e}$ & $\mathrm{e}$ \\
\hline & 2 & $\mathrm{~d}$ & $f$ & $b$ & $b$ & $d$ & $f$ & $\mathrm{e}$ & $\mathrm{d}$ & $C$ & $\mathrm{e}$ & $\mathrm{b}$ \\
\hline & 3 & $\mathrm{e}$ & $f$ & $C$ & $b$ & $\mathrm{e}$ & $d$ & $f$ & $\mathrm{e}$ & & $\mathrm{e}$ & $\mathrm{e}$ \\
\hline & 4 & $\mathrm{~d}$ & $\mathrm{e}$ & $d$ & $\mathrm{~d}$ & $b$ & $\mathrm{C}$ & $\mathrm{d}$ & $f$ & & $\mathrm{e}$ & $\mathrm{e}$ \\
\hline & 5 & $\mathrm{e}$ & $\mathrm{d}$ & $\mathrm{d}$ & $\mathrm{C}$ & $\mathrm{b}$ & $\mathrm{C}$ & $\mathrm{e}$ & $\mathrm{e}$ & & $f$ & $\mathrm{~d}$ \\
\hline & 6 & $\mathrm{e}$ & $\mathrm{d}$ & $\mathrm{d}$ & $b$ & C & $\mathrm{d}$ & $\mathrm{e}$ & $\mathrm{d}$ & $\mathrm{d}$ & $\mathrm{d}$ & $\mathrm{d}$ \\
\hline & 7 & $\mathrm{e}$ & $\mathrm{d}$ & $\mathrm{d}$ & $\mathrm{C}$ & $\mathrm{C}$ & $f$ & $f$ & $\mathrm{e}$ & $\mathrm{d}$ & $\mathrm{e}$ & $\mathrm{d}$ \\
\hline & 8 & $\mathrm{e}$ & $\mathrm{d}$ & & $b$ & $\mathrm{C}$ & $\mathrm{d}$ & $f$ & $\mathrm{e}$ & $\mathrm{C}$ & $\mathrm{e}$ & $\mathrm{C}$ \\
\hline & 9 & $\mathrm{~d}$ & $f$ & $\mathrm{e}$ & $\mathrm{d}$ & $\mathrm{e}$ & $\mathrm{C}$ & $\mathrm{d}$ & $\mathrm{e}$ & $\mathrm{e}$ & $f$ & $\mathrm{e}$ \\
\hline \multirow{9}{*}{$D$} & 1 & $\mathrm{f}$ & $\mathrm{e}$ & $\mathrm{e}$ & $\mathrm{C}$ & $\mathrm{d}$ & C & $f$ & $f$ & $\mathrm{~d}$ & $f$ & $\mathrm{e}$ \\
\hline & 2 & $b$ & $a$ & $a$ & $a$ & $a$ & $a$ & $a$ & $\mathrm{a}$ & $\mathrm{d}$ & $a$ & $\mathrm{a}$ \\
\hline & 3 & $a$ & $b$ & a & $b$ & a & $\mathrm{b}$ & $\mathrm{b}$ & $b$ & $b$ & a & a \\
\hline & 4 & $a$ & C & $\mathrm{e}$ & $\mathrm{d}$ & $d$ & $C$ & $a$ & $b$ & $a$ & a & a \\
\hline & 5 & $\mathrm{e}$ & $\mathrm{d}$ & $\mathrm{d}$ & $b$ & $\mathrm{e}$ & $\mathrm{d}$ & $f$ & $f$ & $\mathrm{C}$ & $\mathrm{d}$ & $\mathrm{d}$ \\
\hline & 6 & $\mathrm{f}$ & $a$ & $b$ & $\mathrm{e}$ & $\mathrm{d}$ & $b$ & $\mathrm{~d}$ & $f$ & & $f$ & $\mathrm{C}$ \\
\hline & 7 & $\mathrm{~d}$ & $\mathrm{e}$ & $b$ & $a$ & $\mathrm{e}$ & $\mathrm{e}$ & $\mathrm{d}$ & $\mathrm{d}$ & $\mathrm{C}$ & $\mathrm{e}$ & $\mathrm{d}$ \\
\hline & 8 & $a$ & $b$ & C & $d$ & a & $\mathrm{e}$ & $\mathrm{b}$ & $\mathrm{C}$ & $\mathrm{C}$ & $f$ & a \\
\hline & 9 & $\mathrm{e}$ & $\mathrm{e}$ & $\mathrm{e}$ & C & $\mathrm{d}$ & $\mathrm{e}$ & $f$ & $f$ & $\mathrm{a}$ & $\mathrm{e}$ & $\mathrm{e}$ \\
\hline \multirow{8}{*}{$E$} & 1 & $\mathrm{e}$ & $d$ & $\mathrm{~d}$ & $\mathrm{e}$ & $C$ & $C$ & $\mathrm{e}$ & $\mathrm{e}$ & $d$ & $\mathrm{e}$ & $\mathrm{d}$ \\
\hline & 2 & $b$ & $\mathrm{a}$ & $a$ & $b$ & C & $\mathrm{C}$ & $\mathrm{C}$ & $b$ & $\mathrm{a}$ & $b$ & a \\
\hline & 3 & $a$ & $\mathrm{~d}$ & $\mathrm{~d}$ & $\mathrm{e}$ & $a$ & $a$ & $\mathrm{~d}$ & $\mathrm{~d}$ & C & $a$ & $\mathrm{a}$ \\
\hline & 4 & $b$ & $b$ & $f$ & a & $a$ & $d$ & $\mathrm{a}$ & $\mathrm{d}$ & $\mathrm{f}$ & $\mathrm{d}$ & $\mathrm{d}$ \\
\hline & 5 & $\mathrm{e}$ & $\mathrm{e}$ & $\mathrm{e}$ & $\mathrm{e}$ & $\mathrm{d}$ & $\mathrm{d}$ & $f$ & $\mathrm{e}$ & $\mathrm{d}$ & $\mathrm{e}$ & $\mathrm{e}$ \\
\hline & 6 & $\mathrm{~d}$ & $b$ & $\mathrm{~d}$ & $\mathrm{e}$ & $\mathrm{e}$ & $\mathrm{d}$ & $\mathrm{a}$ & $b$ & $f$ & $\mathrm{~d}$ & $b$ \\
\hline & 7 & $a$ & $\mathrm{e}$ & $a$ & $a$ & $b$ & $a$ & $f$ & $a$ & C & $a$ & $\mathrm{e}$ \\
\hline & 8 & $\mathrm{e}$ & $b$ & $\mathrm{~d}$ & $a$ & $\mathrm{~d}$ & $\mathrm{a}$ & $\mathrm{b}$ & $\mathrm{e}$ & $\mathrm{e}$ & $\mathrm{a}$ & $\mathrm{d}$ \\
\hline
\end{tabular}




\section{Anexo B}

\section{Carta de encaminhamento do questionário}

\section{Propósito e Instruções:}

Caro colega, esta pesquisa tem como finalidade identificar e qualificar os resultados da implementação da metodologia KAIZEN nas empresas fabricantes de médio porte.

Procurei fazer de forma bem sucinta as questões mais importantes relacionadas ao assunto mencionado para não tornar a resposta deste questionário muito cansativa. Ao término desta pesquisa, todos que fizeram a gentileza de contribuir receberão uma cópia da dissertação ao qual faz parte este questionário.

Sua contribuição é muito importante para que possamos levantar dados que tenham valor para todos aqueles interessados neste tema.

Não é necessário identificar-se nominalmente. Mas sua participação é imprescindível.

Responda somente aquilo que sentir que seria uma resposta consciente, caso contrário deixe a questão em branco.

Dividi o questionário em blocos para facilitar o encaminhamento das questões. No início de cada bloco existirão instruções específicas para preenchimento.

Para assinalar a escolha em cada questão basta colocar a letra " $X$ " na frente da opção desejada.

Muito agradecido!!!

*Todas as informações serão tratadas confidencialmente. No relatório final não serão identificados os respondentes individualmente.

Cordialmente

Argélio Lima Paniago

Escola Politécnica da Universidade de São Paulo

Dept $^{\circ}$ de Engenharia Mecânica

apaniago@ibest.com.br

551934130078 


\section{Anexo C}

\section{Questionário para levantamento Amostral (SURVEY)}

Tema: Kaizen - Implementação em Indústria Metalúrgica de Autopeças: Resultados na redução das perdas na área produtiva.

Objetivo: Analisar os métodos, as dificuldades e resultados na implementação da metodologia KAIZEN em fabricantes de autopeças.

\section{BLOCOS}
A- Identificação da Empresa
B- Estrutura de Gestão da Manufatura
C- Ambiente no chão de fábrica
D- Implementação de atividades KAIZEN
E- Resultados
F- Outros aspectos

\section{A- Identificação da Empresa}

Favor fornecer neste bloco as informações para identificar sua empresa que irão permitir a realização de análise cruzada em relação aos resultados finais.

1- Qual é o principal produto da Empresa?

2- Existem outros negócios ou ramos de atuação?

3- A Empresa é controlada por capital:

a- Nacional

b- Estrangeiro

4- Quantas Unidades no Brasil?

5- Quantos Funcionários na Unidade pesquisada? 


\section{B- Estrutura de Gestão da Manufatura}

O objetivo deste bloco é o de identificar o quanto está avançado o processo de melhoria contínua na sua empresa e qual sua abrangência. Portanto as respostas deverão ser de acordo com a realidade atual, de forma genérica, na empresa.

1- Quanto o conceito de valor agregado e valor não agregado estão estabelecidos na Empresa?
a- Não está estabelecido
b- Muito pouco
c- Pouco
d- Razoável
e- Grande
f- Muito grande

2- Sua Organização tem realizado iniciativas estruturadas para melhoria de produtividade?
a- Nenhuma
b- Muito pequena
c- Pouca
d- Razoável
e- Grande
f- Muito grande

3- Qual o nível de barreiras que você identifica para as iniciativas de melhoria na Manufatura?
a- Nenhuma
b- Muito pequena
c- Pouca
d- Razoável
e- Grande
f- Muito grande

4- Quantas áreas de manufatura foram mapeadas em relação ao fluxo de valor (Value Stream Map)?
a- Nenhuma
b- Muito poucas áreas
c- Poucas Áreas
d- Metade das Áreas
e- Grande parte
f- Todas as Áreas 
5- O ambiente da Manufatura é aberto para mudanças?
a- Não
b- Muito pouco
c- Pouco
d- Razoável
e- Grande
f- Muito grande

6- Existe alguma política para alinhamento da cadeia de fornecimento em relação às propostas de gestão da manufatura?
a- Nenhuma
b- Muito pequena
c- Pouca
d- Razoável
e- Grande
f- Muito grande

7- A introdução de novas tecnologias leva em consideração a redução das perdas de Manufatura?
a- Não
b- Muito pouco
c- Pouco
d- Razoável
e- Grande
f- Muito grande

8- Há uma consideração em relação à redução dos estoques?
a- Nenhuma
b- Muito pequena
c- Pouca
d- Razoável
e- Grande
f- Muito grande

9- A política de desenvolvimento de pessoal é:
a- Nenhuma
b- Muito pequena
c- Pouca
d- Razoável
e- Grande
f- Muito grande 


\section{C- Ambiente no chão de Fábrica}

Este bloco dá ênfase ao "chão de fábrica" e deve ser respondido novamente, assim como no bloco anterior, de acordo com a realidade atual da situação em sua empresa.

1- A Liderança do chão de fábrica conduz atividades ou iniciativas de melhorias?

$$
\begin{aligned}
& \text { a- Nenhuma } \\
& \text { b- Muito pequena } \\
& \text { c- Pouca } \\
& \text { d- Razoável } \\
& \text { e- Grande } \\
& \text { a- Muito grande }
\end{aligned}
$$

2- Houve algum envolvimento de Consultoria para algum tipo de atividade de melhoria no chão de fábrica?
a- Nenhuma
b- Muito pequena
c- Pouca
d- Razoável
e- Grande
f- Muito grande

3- Nas atividades de melhoria do chão de fábrica há a participação efetiva dos Operadores?
a- Nenhuma
b- Muito pequena
c- Pouca
d- Razoável
e- Grande
b- Muito grande

4- As atividades de melhorias no chão de fábrica têm continuidade?
a- Nenhuma
b- Muito pequena
c- Pouca
d- Razoável
e- Grande
f- Muito grande

5- O conhecimento básico nos conceitos da eliminação das perdas, por parte dos Operadores é:
a- Nenhum
b- Muito pequeno
c- Pouco
d- Razoável
e- Grande
f- Muito grande 
6- Há grupos multifuncionais com capacidade para desdobramentos e tomadas de decisão?
a- Nenhum
b- Muito pequeno
c- Pouco
d- Razoável
e- Grande
f- Muito grande

7- A capacidade da Liderança para lidar com as variações de demanda é:
a- Nenhuma
b- Muito pequena
c- Pouca
d- Razoável
e- Grande
f- Muito grande

8- A gestão da Manufatura contempla os diversos ambientes resultantes dos processos de mudança?
a- Nenhuma
b- Muito pequena
c- Pouca
d- Razoável
e- Grande
f- Muito grande

9- Os critérios de competência, conhecimento e habilidades estão definidos para os cargos de chão de fábrica?
a- Não
b- Muito pouco
c- Pouco
d- Razoável
e- Grande
f- Muito grande 


\section{D- Implementação de Atividades KAIZEN}

Neste bloco as questões foram elaboradas sobre o pressuposto de que existem atividades KAIZEN em sua empresa, pois esta foi uma das primícias para escolha de distribuição dos questionários.

1- As atividades KAIZEN são organizadas estruturadamente?
a- Não
b- Muito poucas vezes
c- Poucas vezes
d- Razoavelmente
e- Muitas vezes
f-Sempre

2- O que motivou a Empresa a iniciar as atividades KAIZEN?

a- Reduzir perdas para implantar a Manufatura Enxuta

b- Imposição da Cúpula diretiva

c- Decisão localizada como meio rápido de redução de custos

d- Melhorar o clima organizacional

e- Para testar a metodologia

f- Outra

3- As atividades KAIZEN foram iniciadas por:
a- Alta Direção
b- Média Gerência
c- Supervisão de Fábrica
d- Atividades voluntárias
e- Consultoria
f- Outra forma

4- Os conceitos do KAIZEN foram divulgados para:
a- Toda a Empresa
b- Toda a área de Manufatura
c- Para algumas Áreas da Manufatura
d- Área Piloto
e- Conforme o direcionamento e priorização de melhorias
f- Não foram divulgados estruturadamente

5- O sistema de sugestões de melhoria tem alcançado a participação do pessoal ?
a- Não
b- Muito pouca
c- Pouca
d- Razoável
e- Grande
f- Muito grande 
6- A Ferramenta aplicada mais frequentemente é:

a- Manutenção Produtiva Total - TPM

b- Redução de tempo de set-up

c- Mapeamento da Qualidade

d- Mapeamento do Fluxo de Processo

e- Criação de Operações Padrão

f- Todas

7- A participação da Área de Recursos Humanos é:
a- Nenhuma
b- Muito Pouca
c- Pouca
d- Razoável
e- Grande
f- Muito Grande

8- Qual a forma de condução das atividades KAIZEN?

a- Comitê diretivo multi-departamental elabora planificação

b- Responsável dedicado conduz

c- Responsabilidade da área de Manufatura

d- Consultoria participativa

e- Não há uma condução estabelecida

f- Outra forma

9- A participação dos Operadores nas atividades KAIZEN é:

a- Nenhuma

b- Muito pouca

c- Pouca

d- Razoável

e- Grande

f- Muito grande 


\section{E- Resultados advindos das atividades KAIZEN}

Neste bloco, as informações sobre os resultados das atividades KAIZEN, não importando quais seriam estas, são muito importantes para a análise final da pesquisa.

1- Houve mudança cultural na Manufatura devido às atividades KAIZEN?

a- Nenhuma

b- Muito pouca

c- Pouca

d- Razoável

e- Grande

f- Muito grande

2- Houve o sentimento de ameaça no ambiente da Empresa por causa do KAIZEN?

a- Não

b- Muito pouco

c- Pouco

d- Razoável

e- Grande

f- Muito grande

3- As melhorias, com relação ao resultado financeiro, contribuíram com o ganho de: a- $1 \%$ a $3 \%$ do faturamento

b- $4 \%$ a $8 \%$ do faturamento

c- Não houve

d- Não foi medido

e- Menos do que $1 \%$ do faturamento

f- Mais do que $8 \%$ do faturamento

4- Como é feita a contabilização das atividades KAIZEN?

a- Conta Contábil exclusiva com gastos previstos no orçamento

b- Contabilizado os gastos na área onde foi aplicada

c- Não houve alteração no plano de contas

d- Ganhos registrados e verificados por pessoal específico

e- Balanço dos ganhos e gastos por período

f- Não há

5- A motivação do pessoal foi melhorada com as atividades KAIZEN?
a. Não
b. Muito pouca
c. Pouca
d. Razoável
e. Muito
f. Muito significativamente

6- Há dificuldade para manutenção dos ganhos? 

a. Não
b. Muito pouca
c. Pouca
d. Razoável
e. Muita
f. Significativa

7- Fatores para o sucesso das atividades
a. Participação da alta gerência
b. Recursos disponíveis
c. Planejamento
d. Treinamento
e. Estrutura de coordenação
f. Apoio da Direção

8- Qual o principal cuidado para sustentar o Programa KAIZEN?
a. Procedimentação após as alterações
b. Verificações periódicas
c. Novas ações de melhorias após as verificações
d. Envolvimento contínuo do pessoal do chão de fábrica
e. Monitoramento da alta direção
f. Outra. Especificar:

\section{F- Outros aspectos}

Por favor, dê sua opinião ou comentário sobre a Metodologia KAIZEN e o impacto que ela pode oferecer na Indústria de Autopeças. 


\section{Anexo D}

\section{Definições relacionadas ao tema KAIZEN:}

- Autopeças - Componentes individuais ou subconjuntos adquiridos junto a fabricantes (fornecedores) previamente selecionados dentro de suas respectivas especialidades pelas Empresas Montadoras de automóveis, tratores e caminhões.

- Empresa de médio porte - Empresas com número de funcionários entre 100 e 499(SEBRAE-Serviço Brasileiro de Apoio às Micro e Pequenas Empresas). Da mesma forma temos: micro empresas ( 1 a 19 empregados) ; pequena empresa (20 a 99 funcionários); grande empresa( mais de 500 funcionários)

- Valor agregado e valor não agregado - Tudo aquilo, no produto ou serviço, que é percebido pelo cliente como valor é considerado valor agregado ao produto, tudo aquilo que não é percebido é valor não agregado.

- Produtividade - Relação entre a saída de um determinado valor e as entradas alocadas para gerá-lo. A relação entre o volume produzido e os recursos necessários a esta produção. Chamamos esta relação de produtividade. Conceitualmente, Produtividade significa capacidade de produzir, característica do que produz com abundância ou lucratividade. Em outras palavras, Produtividade é obter a melhor relação entre volume produzido e recursos consumidos. Portanto, se representarmos matematicamente a Produtividade teremos: Produtividade $=(A) /(B)$, onde $(A)$ representa o volume produzido e (B) os respectivos recursos consumidos. Para conseguirmos aumentar a Produtividade devemos atuar no aumento de (A) e ao mesmo tempo manter (B) constante, ou seja, aumentar o volume produzido sem aumentar o consumo dos recursos necessários para sua execução, ou então, manter (A) e diminuir (B), o que significa manter o volume produzido, porém consumindo menos recursos (Sumanth,1984)

- Fluxo de valor - Entende-se por fluxo de valor o conjunto de todas as atividades que ocorrem desde a obtenção de matéria prima até a entrega ao consumidor do produto final (Rother e Shook, 1996). 
- Gestão da Cadeia de Suprimentos (Supply Chain Management) - Gestão na qual as empresas interessadas na obtenção de vantagens competitivas de forma efetiva buscam uma visão expandida, atualizada e, sobretudo, holística da administração de materiais tradicional, abrangendo a gestão de toda a cadeia produtiva de uma forma estratégica e integrada. Pressupõe, fundamentalmente, que as empresas devem definir suas estratégias competitivas e funcionais através de seus posicionamentos (tanto como fornecedores, quanto como clientes) dentro das cadeias produtivas nas quais se inserem (Collins, R.S.; Bechler, K.; Pires, S.R.I.,1997)

- Perda - Segundo Ohno(1988), tudo aquilo que não agrega valor na manufatura é considerado perda ou desperdício(7 desperdícios identificados no Sistema Toyota de Produção: excesso de produção; esperas; retrabalhos; inventário; movimentos desnecessários do Empregado; peças defeituosas).

- Grupos multifuncionais - Times com pessoal com especialidades diversas reunidos por um determinado tempo com a finalidade de resolução de problemas ou desenvolvimento de melhorias. "O objetivo dos grupos multifuncionais é o de melhorar o desempenho pelo envolvimento de todos os funcionários de encontro às necessidades dos clientes" (Lynch e Werner, 1994, p. 35).

- Manufatura Enxuta - Termo mencionado por Womack et al.(1992) em seu livro a máquina que mudou o mundo, significando um sistema de produção ou serviços no qual as perdas são minimizadas.

- Alta Direção - Nome dado à Direção Executiva de uma Empresa

- Média Gerência - Nome dado aos Gerentes intermediários em uma Empresa, os quais participam de parte do direcionamento tático e são responsáveis pelas implementações operacionais.

- Liderança - Supervisores e Líderes responsáveis diretos pelo andamento do "dia a dia" das operações de fabricação ou prestação de serviços.

- Set-up - Operação de troca de ferramentas em uma máquina ou linha de produção. Operação realizada com a finalidade de se trocar uma série por outra de produto ou item.

- Mapeamento da Qualidade - Processo em que se registram todas as etapas de produção e se verificam todos os problemas de qualidade relativos a cada 
etapa. A partir desta verificação se estabelecem ações para eliminar ou prevenir os problemas.

- Operações padrão - Cada etapa do processo produtivo é chamada de operação e "Operação padrão" é o conjunto de instruções padronizadas para execução desta operação 